\title{
Iron and the Bloody Shirt: Leadership in the West Virginia Republican Party 1872-1896
}

\author{
Stephen A. Smoot \\ West Virginia University
}

Follow this and additional works at: https://researchrepository.wvu.edu/etd

\section{Recommended Citation}

Smoot, Stephen A., "Iron and the Bloody Shirt: Leadership in the West Virginia Republican Party 1872--1896" (2011). Graduate Theses, Dissertations, and Problem Reports. 3463.

https://researchrepository.wvu.edu/etd/3463

This Dissertation is protected by copyright and/or related rights. It has been brought to you by the The Research Repository @ WVU with permission from the rights-holder(s). You are free to use this Dissertation in any way that is permitted by the copyright and related rights legislation that applies to your use. For other uses you must obtain permission from the rights-holder(s) directly, unless additional rights are indicated by a Creative Commons license in the record and/ or on the work itself. This Dissertation has been accepted for inclusion in WVU Graduate Theses, Dissertations, and Problem Reports collection by an authorized administrator of The Research Repository @ WVU.

For more information, please contact researchrepository@mail.wvu.edu. 
Iron and the Bloody Shirt: Leadership in the West Virginia Republican Party 1872-1896

\section{Stephen A. Smoot}

Dissertation submitted to the Eberly College of Arts and Sciences at West Virginia University in partial fulfillment of the requirements for the degree of

Doctor of Philosophy in History

Kenneth Fones-Wolf, Ph. D., Chair Elizabeth Fones-Wolf, Ph. D. Jack Hammersmith, Ph. D. Tyler Boulware, $\mathbf{P h}$. D. Kevin Barksdale, Ph. D.

\section{Department of History}

Morgantown, West Virginia 


\section{ABSTRACT \\ Iron and the Bloody Shirt: Leadership in the West Virginia Republican Party 1872-1896}

Stephen A. Smoot

The electoral upheavals of 1894 and 1896 resulting in Republican Party dominance within West Virginia and around the nation were not just a sudden occurrence. They resulted, in part, because voters in key border states shifted their votes from the Democratic to the Republican Party. West Virginia's Republican Party had the greatest success in maintaining its long term influence after 1896 despite the fact that since 1872 it enjoyed little success. To build up to triumph in 1896 took a quarter century of painstaking work that started after electoral disaster in 1870. That election, the first since West Virginia removed restrictions on former Confederates, brought Democrats into a position of dominance. This dissertation tells the story of how West Virginia's Republicans rebuilt their party between 1872 and 1896.

Nathan Goff, a Union Army major during the Civil War, used the same methods as other party authorities around the country. He used his talent for public speaking and access to federal patronage to mobilize and reward the faithful as much as possible. State Republican newspapers battled their Democratic counterparts in conflicts over not only issues of the day, but also anger over measures taken during the Civil War. Goff's work helped to restore a working party organization in the 1870s, but did not put West Virginia Republicans into a position to return to competitiveness, much less power. Money, manpower, and organization do not ensure success without a relevant message.

The Republican Party across the country started to fashion a more appealing vision after the difficult Grant and Hayes Administrations. They advocated sound money and a protective tariff as cornerstones of national prosperity more often during the 1880s. Goff emerged as a national spokesman for protectionism at the same time as the Second Industrial Revolution started strongly transforming West Virginia's economy. However, national economic conditions in this decade did not result in massive movement towards the Republican cause. Instead, the country experienced partisan deadlock. West Virginia Republicans made gains during this decade. In 1888, Goff came very close to capturing the office of governor. The Democratic legislature successfully counted out enough votes to seat the Democratic nominee, but the results demonstrated a shift in party power.

Goff would not be able to take West Virginia Republicans to their eventual triumph. The year 1888 also saw Goff unseated as party chief by the nationally known Stephen Benton Elkins. Elkins built up a fortune in land speculation, railroads, and other ventures. Along the way, he married the daughter of former Senator Henry Gassaway Davis, a prominent West Virginia Democrat and industrialist. Elkins brought a new kind of leadership style to West Virginia Republican politics. He concentrated on building a stronger and more 
effective party organization more than relying on personal appeal in speeches and debates. Elkins was exceptionally good at keeping divisive issues and potentially conflicting personalities from interfering with party goals.

The economic crisis that gripped the nation during the election year of 1894, a time of plummeting production and employment figures, made the Republican economic vision more appealing to voters. Grover Cleveland and his party did not seem to have the answers to the problems that many faced. West Virginia's Republican organization built by Elkins was able to take full advantage of the national party campaigns. They did not simply convince West Virginians to vote for Republican candidates, but to trust the party to direct state affairs for the next generation. This dissertation helps to put West Virginia's Republican Party experience into a national perspective while also explaining why the state shifted into the GOP column so strongly after 1896. Leadership, message, and the choices made by voters all play into this dramatic political shift. 


\section{ACKNOWLEDGMENTS}

A dissertation, like most worthwhile endeavors, is less of a work and more of a journey. Sometimes one breaks into open country and easily makes substantial progress. However, all too often the traveling becomes slow and difficult as obstacle after obstacle forms to block your path. Mountains form before your eyes and swamps extend beneath your feet. Some of this is related to the work. Much of the rest comes when you have to find the right balance between work and life. There are no rules, nor are their guidelines. None who make this journey, at least in the humanities, do so because there is a pot of gold at the end of the rainbow. Were we solely looking for that, most of us would have gone to law school. Instead, we put ourselves through this so you, the researcher or casual reader, have a convenient way to access the subject and (hopefully) a thought provoking point of view. Of course we are also looking for professional position and respect.

Those of us who are lucky embark on the journey with excellent guides. In my first few years, I studied under Ronald Lewis, Mary Lou Lustig, Robert Blobaum, and Jason Parker. Though the fields varied tremendously, I could always see threads of thought in some that helped give perspective to others. I especially appreciate the advice from Professor Lewis when trying to think of where this dissertation would go. Additionally, my dissertation committee's advice and guidance was vital to making this dissertation clear and concise. I appreciate the contributions of Kenneth and Elizabeth Fones-Wolf, Tyler Boulware, Kevin Barksdale, and Jack Hammersmith, especially the eternal patience of Professor Ken Fones-Wolf as he and I worked through revisions. 
I also could not have completed this journey without the love and support of my fellow travelers. Sometimes it shocks me that they elected to see it all through, but they shared the excitement and the anxiety of this whole process and I am forever grateful. My wife, Crystal, has always given me her complete love and support in this endeavor and my children, Jared and Emily, have had to come along for the ride. Jared is twelve and probably has no memory of my not working on this. My parents' support, moral, financial, and otherwise, was also vital in making sure that we could continue our travels. West Virginia University’s Department of History took a chance on me in 2003. I am deeply thankful that they did. I received a top notch education and had the privilege of working with outstanding faculty and graduate students. Finally, I would also like to acknowledge two professors from Marshall University to whom I looked to as mentors, David Woodward and the late Robert Maddox. I borrowed most of my teaching style from their examples. They also are the reason that I decided to go into higher education rather than some other field. There are also too many friends to name here whose help and support have been tremendous.

This journey has ended, but it only prepares me for the next. Thanks to all! 


\section{TABLE OF CONTENTS}

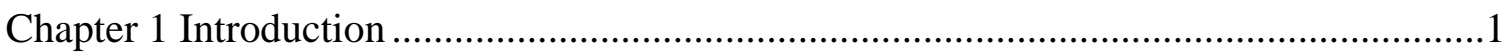

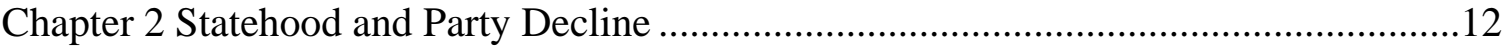

Chapter 3 Nathan Goff and the Perils of Party Rule........................................................58

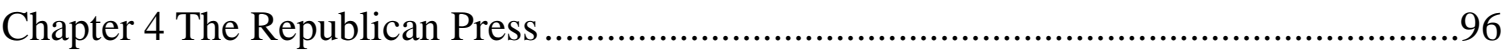

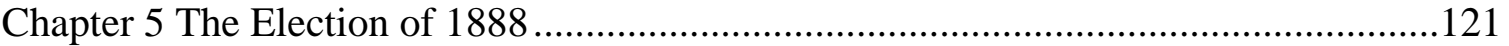

Chapter 6 Stephen B. Elkins and Management Style Leadership ................................160

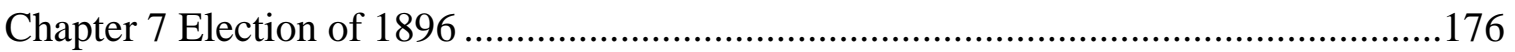

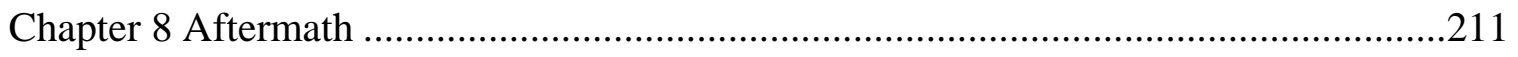




\section{CHAPTER ONE}

\section{INTRODUCTION}

West Virginia has never seen an extended period of two party competition. In some decades the Democratic Party dominated registrations and filled most elected positions while Republicans controlled other eras. The first thirty years after the conclusion of the Civil War saw two major party shifts within the state of West Virginia. Republicans founded West Virginia, then tried to strengthen the new state and the party's hold on power at the same time. They succeeded in establishing the state and its government permanently and even sold most voters on issues such as development and education, but could not maintain their dominance. By 1872, the Democratic Party had regained control and even ratified a new constitution. Democrats controlled state politics for the next twenty years until Republicans once again successfully challenged for ascendency. How did Republicans lose the support of the electorate in the early 1870s, then regain it two decades later? What effect did it have on the early development of the state up to the turn of the century? In what ways did the West Virginia Republican Party’s push for dominance in the 1890s have an effect on national political shifts?

Two historians have largely contributed to creating the framework of understanding late nineteenth-century West Virginia politics. One, Gordon McKinney, has emphasized how the mountain experience shaped politics from West Virginia to northern Georgia. According to McKinney, people in the mountain sections of southern states experienced geographical prejudice, lived in "destitute” conditions, and tended to 
perceive the Civil War in personal terms. ${ }^{1}$ Splits over black voting and the Civil Rights Act of 1874 destroyed party unity. ${ }^{2}$ McKinney argued that West Virginia Republicans responded by rallying behind a war hero, Nathan Goff Jr., and modeled their party along military lines. ${ }^{3}$ With this new organization they revamped their approach, focusing less on national and more on local issues Reconstruction's end helped to close the door on a difficult issue for Republicans to defend as the Civil War receded into history. ${ }^{4}$ By the 1880s, according to McKinney, Goff's decisions about patronage and his campaign tactic of false reluctance to run for office created strains between him and other party leaders. Stephen Elkins, a wealthy operator in national presidential politics, took advantage of Goff's weakening position and established himself as a more reliable dispenser of patronage. ${ }^{5}$ West Virginia was unique, however, for Republicans, concentrated in the mountains of the other southern Appalachian, states found it difficult to combat the increasingly entrenched authorities in lowland state capitals. ${ }^{6}$ The lowland versus highland dynamic did not exist in West Virginia to the same degree as in other Appalachian states that had not split.

The other major interpretation comes from John Alexander Williams, who succinctly presented his interpretation of West Virginia’s Gilded Age political developments in the first sentence of West Virginia and the Captains of Industry: "In the last third of the nineteenth century, the gods of war and commerce created a new

\footnotetext{
${ }^{1}$ Gordon McKinney, Southern Mountain Republicans, 1865-1900: Politics and the Appalachian Community, (Chapel Hill: University of North Carolina Press, 1978), 13, 19, 24.

${ }^{2}$ Ibid, 43.

${ }^{3}$ Ibid, 64.

${ }^{4}$ Ibid., 86.

${ }^{5}$ Ibid., 151, 153.

${ }^{6}$ Ibid., 9.
} 
American commonwealth in the heart of the Appalachian highlands." ${ }^{, 7}$ This dramatic opening leads into a discussion of how party mattered little as West Virginia industrialized. Industrial leaders drove both parties towards the same goals. His book goes on to describe a tightly interwoven relationship between West Virginia’s political system and its emerging industrial economy. Williams' highlights the impact of industrial politicians Elkins, Johnson Camden, Henry Gassaway Davis, and Nathan Scott on the economic, political, and social system of the state. This group includes two Democrats and two Republicans; they and their peers in politics and industry, according to Williams, created a modern political system designed to create profit for themselves and "metropolitan industrialism." ${ }^{8}$ Ronald L. Lewis in Transforming the Appalachian Countryside agrees with Williams that extractive industries and business in general dominated the political system of the state. Lewis argues that "historians generally have not explained the political and legal changes implemented in the statehouses and courthouses of the region in support of the industrial transition." ${ }^{9}$ Lewis also discusses the impact of a population that wanted jobs and development.

Williams and Lewis emphasize economics in these studies. Williams especially implies that the political movements came secondary to the economic while Lewis discusses the transformation of legal interpretations. This dissertation differs from their studies in asserting that the role of political parties with their leadership, ideas, organization, and supporters played a strong part in the development of the political system that emerged in West Virginia.

\footnotetext{
${ }^{7}$ John Alexander Williams, West Virginia and the Captains of Industry (Morgantown: West Virginia University Libraries, 1976), 1.

${ }^{8}$ Ibid., 4.

${ }^{9}$ Ronald Lewis, Transforming the Appalachian Countryside: Railroads, Deforestation and Social Change in West Virginia, 1880-1920 (Chapel Hill: University of North Carolina Press, 1998), 11.
} 
More recent studies have added nuance to these basic frameworks. Randall Scott Gooden, in his 1995 dissertation, helped to explain the Republicans’ assumption of power during the Civil War and their loss of power by the 1870s. He stressed the revolutionary nature of the changes that took place during the Civil War in West Virginia. Gooden examined the early party movement as a whole, as well as individual differences within it. Radically oriented Republicans needed Union Democrats to create a new regime in West Virginia, but alienated them with the postwar policies that shut out former Confederates. ${ }^{10}$ Tensions and schisms, even among the victors, threatened to undo the creation of the state and all the reforms that came with it, such as free public schools. ${ }^{11}$ Many of these problems emerged from the presidency of Andrew Johnson whose lack of tact and brazenly pro-Southern policies divided the ranks of the Union coalition by the end of his presidency. Democrats and Republicans almost completely split along party lines over the important issue of President Johnson's possible removal from office. The growing weakness of the Union movement helped to propel state Republicans and Governor Arthur I. Boreman toward more severe measures, such as the imposition of test oaths for voting and even working in certain professions. ${ }^{12}$ West Virginia did successfully begin its revolutionary transformation into an industrial economy with northern style innovations, such as free schools. Democrats even kept most of the changes when they created their own state constitution in 1872. However, according to Gooden, the moderate "let up” Republicans found themselves cut adrift when ex

\footnotetext{
${ }^{10}$ Randall Scott Gooden, "The Completion of a Revolution: West Virginia From Statehood Through Reconstruction” (Ph.D. diss., West Virginia University, 1995), 25, 26.

${ }^{11}$ Ibid., 26, 31.

${ }^{12}$ Ibid., 136.
} 
Confederates returned to the franchise. ${ }^{13}$ The splits created within the Republican Party hurt it almost as badly as the lingering negative memories among many Democrats about the postwar anti-Confederate measures.

Revolution admittedly is a slippery term. In this work, the term is used to describe the elimination of a formerly dominant system through violence, then the implementation of a new order by leaders who generally come from outside of the old system. Republicans in pre Civil War Western Virginia were very few in number. Industry remained a goal for certain selected areas. No serious individual proposed independence for the counties of the future state in 1859. The state leaders of the postwar period aimed West Virginia down a different path towards statehood, Republican rule, and new economic patterns.

Other scholars have helped put West Virginia’s partisan competition into a national perspective, thus highlighting its importance. Robert Cherny's study, American Politics in the Gilded Age, revolves around the idea that political gridlock defined a generation of American politics starting with Ulysses S. Grant and ending with Benjamin Harrison. Presidents in this period specialized in administrating rather than initiating. ${ }^{14}$ Political parties dominated American political life and thinking more than almost any other era. Party identification included not only regulars, but factionalists, and brief appearances of third parties. The difference between this era and the twentieth century was the lack of many other organizational distractions to seize the attention of people. According to Cherny, most voters would have agreed with Senator Roscoe Conkling who

\footnotetext{
${ }^{13}$ Ibid., 309. "Let up” Republicans favored the removal of restrictions on former Confederates.

${ }^{14}$ Robert W. Cherny, American Politics in the Gilded Age: 1868-1900 (Wheeling, IL: Harlan Davidson, 1997), 50.
} 
explained that "I do not know how to belong to a party a little." ${ }^{\text {,5 }}$ Increasingly close elections, narrowing gaps between the major parties in Congress, and the ability of third parties to command influence beyond their numbers created conditions that made electoral victories extremely vital, even if they came at the expense of principles. Harrison and McKinley broke through the deadlock with their backing of the Republican economic program of sound money, admission of new states, an anti-trust act, and a protective tariff. ${ }^{16}$

The role of the Republican economic program lies at the center of Richard Bensel's The Political Economy of American Industrialization. Bensel asserts that the combined efforts of northern capital and the Republican Party functioned to redistribute resources away from the South into the industrial belt, thereby building an effective political coalition of northern businessmen and industrial workers. Although industrialization for most countries was a painful process, Bensel argues that America's path was rare because it took place in a relatively democratic state. Other industrial societies used some form of authoritarian tactics, but the Republican Party in the United States had to recruit constituents and sell them on the benefits. ${ }^{17}$ The post Civil War era introduced conditions that would lead to an industrial explosion, such as the lowering of interstate barriers to commerce. ${ }^{18}$ The protective policy of the United States lay at the center of Republican economic and political ideology. Most countries used the tariff as part of a foreign policy vision. Republicans used it, according to Bensel, to fund Union

\footnotetext{
${ }^{15}$ Ibid., 13.

${ }^{16}$ Ibid., 92.

${ }^{17}$ Richard Bensel, The Political Economy of American Industrialization: 1877-1900 (Cambridge University Press, Cambridge, 2000), 3.

${ }^{18}$ Ibid., 349.
} 
veteran pensions. Those pensions helped to secure a generation of grateful voters. ${ }^{19}$ As a state on the southern border of an expanding industrial belt, West Virginia was poised to take advantage of this industrial economy, benefitting a significant population of Union veterans and workers.

This dissertation focuses on these past interpretations of state political history by examining the development of the state Republican Party. It discusses its ideas, personalities, methods, and impact. Williams examines the industrialist-politicians as representatives of a class rather than a political party. Lewis and others focus on economics and society, leaving politics as a secondary discussion. The research in this dissertation focuses instead on the leaders and mid level personalities who led and worked for the state party as well as the ideas and issues that motivated them. It examines the changes and developments that were vital to the party's success in the 1890s. The West Virginia Republican organization between the 1860s and the 1890s transformed itself from one reliant upon anti-Confederate restrictions similar to those in the South to a northern style party in the 1890s. This transformation occurred because the people of the state increasingly supported industrialism and its defining issues, such as protectionism, bringing it closer to the northern agenda. Shifting voter allegiances from the Democratic to the Republican Party had national ramifications. West Virginia joined a core group of states that generally supported the Republican Party until the Great Depression.

This work will examine the inside stories of power and influence found in the personal papers of leaders, elected officials, and other parts of the party hierarchy. Admittedly several works touch on the details of these maneuverings. Goff had to

\footnotetext{
${ }^{19}$ Ibid., 457, 458.
} 
sidestep the statemakers to get into power and find ways to keep strong personalities satisfied with his authority. Goff had to deal with different administrations that had different priorities, but his state party's struggles did not mirror the divisions of the Stalwarts and Liberals. ${ }^{20}$ He also learned that supporting the wrong presidential candidate brought political consequences. Meanwhile, politically active Republicans tried to position themselves to receive federal patronage appointments. These offices served to reward the faithful, employed the elderly who have rendered service but had trouble supporting themselves, and identified favorite lieutenants. Patronage influence also identified which party leaders were in ascendancy and which were in decline.

West Virginia Republicans performed best when they could come to agreement on key issues. Principles often, but not always, united otherwise contentious individuals in a common cause. This dissertation shall investigate the importance of the issues they promoted as well as how they unified and divided the party. Fear of losing their state and the changes they made in the initial constitution kept statemaker Republicans unified. By the late 1860s, anxiety over denying fellow Americans basic rights outweighed the apprehensions over what might happen if the Democrats regained power. The demise of the ideological bonds that drove the first generation of Republicans coincided with the onset of Cherny’s period of political deadlock. Republican control of the presidency and Congress could not help to build a state party organization capable of retaking power until it assembled a program compelling enough to interest state voters. That came in the form of the economic program gradually formed by the 1880s. Bensel argues that post Civil War industrialization amounted to a redistribution of wealth from the South to the

\footnotetext{
20 "Stalwarts" in the 1870s tended to support President Grant and the party bosses. "Liberals" drew much of their leadership from journalists and other intellectuals who saw the Stalwarts as sacrificing the basic principles of the party.
} 
Northeast. National economic policy increasingly shielded manufacturing while exposing export oriented agrarian interests to retributive tariffs. ${ }^{21}$ Redistribution of wealth probably does not describe the situation as accurately as a reprioritization of the economy. The program crafted by Republicans aimed at maintaining prosperity and creating a strong voter base. In West Virginia, one sees an excellent example of creating a base of activists through patronage. Those rewarded with federal jobs actively helped to promote the party and its candidates. Furthermore the party relied upon partisan newspapers to promote its ideas and policy proposals. In 1888 the Goff organization launched a major statewide test of its strength against the strongly divided Democratic Party. Goff himself personified the effort by running (reluctantly) for governor and losing by a very slender margin after all investigations concluded. The narrow setback compared to earlier examples of Democratic electoral dominance demonstrated the weaknesses and division of that party. It also showed the limited ability of Goff to get the Republicans into a position of power in increasingly favorable circumstances.

The regional impact of the new policies and the Republican message illustrated the complexity of the changing nature of different parts of the country during the Second Industrial Revolution. Industries emerged in the old Confederacy, such as ironworks in Alabama. The industrial belt's extension across the Great Lakes and Ohio Valley coexisted with agriculture. Making industry a priority, as Bensel described, had an impact in West Virginia and other border state regions. West Virginia gravitated economically from its reliance on agriculture to one based on extractive industries and manufacturing. Republicans in West Virginia gradually built strength as the Democratic Party started to fracture in the 1880s over the gold standard and the tariff. At the same

${ }^{21}$ Bensel, The Political Economy of American Industrialization, 467. 
time, the Republican program was taking shape and the party organization was exploring better ways to disseminate its message. Economic crisis in the early 1890s exposed the Democratic Party’s inability to govern. ${ }^{22}$ This allowed for a Republican political expansion into the border states and West in the 1890s. ${ }^{23}$

The 1890s were a key milestone in West Virginia Republican development. The party moved from an era of building a viable opposition into developing an institution capable of control and even dominance. Earlier, Goff had maintained the party through charisma and patronage, but could not push it over the top. Elkins came along at the right time in history with the right managerial strategies to keep Republicans relatively unified as they took over the state. On issues of industrial development, West Virginia and other border states believed that the Republican Party had a stronger and more coherent message based on protection and sound money. This dissertation uses West Virginia's experience as a case study of political evolution from post Civil War issues to those of development. This shift broke down what Cherny described as a "deadlock" between the parties. ${ }^{24}$ Elkins’ influence and leadership made West Virginia’s Republican Party a part of the process rather than an organization dragged along by history. Not only did he continue to build on Goff's successes, but Elkins also emerged as an important power figure representing a state now much more influential in the field of national politics. ${ }^{25}$

The case study of the West Virginia Republican Party demonstrated that a state party and its leadership can find themselves confined by national problems and priorities,

${ }^{22}$ Cherny, American Politics in the Gilded Age, 110.

${ }^{23}$ Bensel, The Political Economy of American Industrialization, 361.

${ }^{24}$ Cherny, American Politics in the Gilded Age, 41.

${ }^{25}$ Stephen Elkins occasionally came up in discussions over the vice presidency and the presidency, Albert Blakeslee White to Stephen Elkins, February 5, 1900, Stephen Elkins Papers, West Virginia and Regional History Collection, West Virginia University, Morgantown West Virginia. Hereafter referred to as "Elkins Papers.” 
but also make a national impact. West Virginia’s Republican Party moved from dominance to near destruction, then gradually back to dominance. Its return to power helped to create the foundation of party strength nationwide. Its story is one of leadership, ideas, perseverance, and old fashioned politics, good, bad, and ugly. It is also a small, but important part of the grand narrative of how the United States rose to become the world's most powerful nation and the role West Virginia played in that process. 


\section{CHAPTER TWO \\ STATEHOOD AND PARTY DECLINE}

West Virginia’s birth and early statehood was as convoluted and unusual as the Civil War itself. Formed from a mixture of sectionalist tradition and national crisis, the Mountain State's birth was to the nation a pragmatic war measure. To supporters of the Union starting in the spring of 1861, it represented their best chance at survival. Strongly intertwined with the formation of the state and the changes it embraced was the Republican Party. Its identification as a Union movement captured the loyalty of many in the mountain districts as well as those who might have preferred the more genteel old Whig party.

A psychological divide in Virginia prefaced the political and social breaks. As a border area, the future state of West Virginia developed differently than the eastern section. David Hackett Fischer’s Albion’s Seed tracks the movement of Scottish, northern Irish and northern English populations from their land of origin to the Virginia backcountry of the 1700s. They settled chiefly in a "7" shaped mass that extended from the Monongahela Valley eastward to the Great Valley and southward along that land feature to the New River. ${ }^{1}$ According to Paul Salstrom, 2,150,000 lived in this region by $1770 .^{2}$ They brought in different ethnic and religious traditions that separated them in some ways from eastern Virginia. Over time, economic ties connected the northern branch of this movement to trade on the Ohio River while those in the Valley of Virginia and the Shenandoah traded with the Chesapeake region. The northerners' economic

\footnotetext{
${ }^{1}$ David Hackett Fischer, Albion's Seed: Four British Folkways in America (New York: Oxford University Press, 1989), 637.

${ }_{2}^{2}$ Paul Salstrom, Appalachia's Path to Dependency (Lexington: University of Kentucky Press, 1994), 2.
} 
interests, cultural ties, and traditions favored ties to Pennsylvania, and their exposed frontier before 1795 made many support the federal government. Virginia failed, in the eyes of many in the western counties, to protect the people during frontier days or to provide economic development in subsequent decades. They would not follow their eastern brethren out of the Union without a fight, given their long standing grievances against Virginia. ${ }^{3}$ As the radicalized Commonwealth made decisive moves toward secession in spring of 1861, westerners had to decide if they loved old Virginia or the Union more.

When the Republican Party formed in 1854, uniting Northern capital with great financial resources, the South saw a red flag. This party had more potential than the Free Soil movement to win elections, and, unlike the Whigs, it did not hesitate to take a position on slavery. ${ }^{4}$ Furthermore Southerners saw its leadership as particularly frightening. Its strategy of forcing the North to concede or face the unthinkable now came under challenge from men such as New York’s William Seward. Seward, Governor of New York in the late 1850s, predicted that Republican control of the government would bring about an end to slavery. ${ }^{5}$ He was an aggressive and highly intelligent politician who grew influential in New York politics and also traveled the globe in anticipation of a presidential nomination. Likewise Northerners watched with confused anxiety as the South held the nation hostage through the latent threat of civil war.

\footnotetext{
${ }^{3}$ John Alexander Williams, West Virginia: A History (Morgantown: West Virginia University Press, 2001), 52.

${ }^{4}$ Judge Samuel Foot of New York, when explaining his move from the Whigs to the Republicans, asked rhetorically "What then is there left of public duty to which the old Whig Party stands pledged? I see nothing except the principle for which we so earnestly contended in 1844, viz, the exclusion of slavery from free soil.” New York Daily Times, 25 October 1855.

${ }^{5}$ New York Times, 28 October 1858.
} 
The American Civil War arose from a variety of causes converging into one massive historical catastrophe. A single event lit the fuse. Abraham Lincoln's election to the presidency demonstrated the extremely rapid ascent for the Republican Party into national leadership. At the party convention of 1860, Lincoln contended with William Seward, among others, for the nomination. Lincoln in 1858 won national attention with his effective rhetorical parries in debates with Stephen Douglas as they campaigned for a US Senate seat in Illinois.

Lincoln’s presidential victory convinced many Southerners that the North intended to crush their world and many responded quickly. On November 5, South Carolina's governor strongly urged the state legislature to consider secession before Lincoln was even actually elected. After his win, federal buildings in Charleston ostentatiously displayed the state flag instead of the stars and stripes while federal officials resigned their posts. The London Times reported in moderate tones that Southerners would express anger, then shift their message by stating "the extreme section in the Slave States have so long and so vehemently asserted their resolve never to submit to a Republican Executive that they could not without becoming ridiculous quietly acquiesce in their defeat.”6

Western Virginians viewed the looming storm with fear and anticipation. Almost two thousand Virginians, nearly exclusively from the northwest, cast their ballots for Lincoln. This gave him a little over $1 \%$ of the vote there, but support was concentrated in the northwestern counties. Furthermore, according to historian Charles Ambler, Western Virginia Democrats more resembled the child of the frontier, Union-loving Jacksonian

\footnotetext{
${ }^{6}$ Ralph E. Weber, ed., As Others See Us: American History in the Foreign Press (New York: Holt Rinehart, 1972), 117.
} 
strain than those that had followed plantation elites like John C. Calhoun a generation before. ${ }^{7}$ A Hancock County farmer wrote to his family on November 11 expressing glee over both the birth of a baby boy and the election of Lincoln. Exactly six months later, he lamented the possibility of having to live in the Confederacy. He stated "we, the people of North Western Virginia will hold a convention the $13^{\text {th }}$ May and declare our independence from our masters in the East. Then what the result will be, God only knows.” The writer finished by tossing the gauntlet towards Virginia, writing with bravado, "beware masters how you cross the Blue Ridge.”8 Waitman T. Willey, a man whose passion for change led him to crusade against alcohol prior to the war, found himself as one of the centers of Unionist sentiment in Virginia. Willey possessed a streak of personal independence that earned him praise and criticism through much of his political career. He was one of only two senators and eight congressmen overall who did not support over half of the Radical Republican agenda between 1861 and $1865 .{ }^{9}$ This tendency to oppose the majority in the cause of what he considered right led him to strongly resist calls for Commonwealth secession. From Portsmouth, Virginia, to Morgantown, devotees of the federal government expressed to him their opposition. ${ }^{10}$ Many westerners rallied against the cause of secession while some of their friends, neighbors, and families flocked towards it. Western Virginia slouched towards the violence of a civil war more recognizable to students of modern irregular warfare.

\footnotetext{
${ }^{7}$ Charles Ambler, West Virginia: The Mountain State (New York: Prentice Hall, 1940), 309.

${ }^{8}$ A. Pittinger to family, November 30, 1860 and April 30,1861, Pittinger Family Letters, West Virginia and Regional History Collection, West Virginia University, Morgantown WV. Unfortunately, the first name was not available.

${ }^{9}$ David Donald, The Politics of Reconstruction, 1863-1867 (Baton Rouge: Louisiana State University Press, 1965), 7.

${ }^{10}$ William Emmerson to Waitman T. Willey, March 12, 1861 and John Ryme to Willey March 12, 1861, Waitman T. Willey Papers, West Virginia and Regional History Collection, West Virginia University, Morgantown WV. Hereafter cited as "Willey Papers."
} 
While armies fought in more conventional fashion in Virginia, Tennessee, and elsewhere, Western Virginia's war often featured raids, bushwhacking, and guerilla style fighting. A century and a half of history had created a cultural, social, and political divide. This divide initially lay between peoples. Westerners kept some affection for Virginia and a primarily agricultural way of life. It certainly did not initially provide a fertile field for the growth of the Republican Party, known among its Southern opponents as the "black" Republicans. ${ }^{11}$ Only the extreme horror of Western Virginia’s civil war could bring about these radical changes. The first step towards radical change lay in a "restoration" that prefaced a new path.

Virginia at first resisted the calls of the rest of the South to leave the Union. Upper South and border states feared the coming of conflict more than their more zealous counterparts farther south and north. The popularity of John Bell and his conflict-averse Constitutional Union Party in the border regions testifies to that fact. ${ }^{12}$ Bell won Virginia, Kentucky, and Tennessee while performing well in Maryland and Missouri. If war came, these states would most likely bear the brunt of the violence. South Carolina and Massachusetts, by virtue of geography, could afford, at least for a while, their bellicosity. Events, however, moved at a rapid pace. All national institutions, from Protestant denominations to the Democratic Party, had split, removing any chance of reconciliation without violence or capitulation. Between the election of Abraham Lincoln and the spring of 1861, the Deep South proclaimed its independence and waited in frustration for the response of the United States government. The incoming president did not oblige them, frustrating aspiring rebels and zealous northerners alike. Instead,

\footnotetext{
${ }^{11}$ Eugene H. Roseboom, A History of Presidential Elections (New York: Macmillan, 1958),184.

12 Ibid., 183.
} 
Lincoln worked to maneuver the South into firing the first shot, guaranteeing maximum public support and perhaps preventing the secession of upper South states. The refusal to evacuate Fort Sumter led to that very result in April when the president issued the call for troops.

Most importantly, at least for those in western Virginia, came the issue of how Lincoln would deal with their commonwealth and the desires of at least some of them for a new state. After Virginia's convention decided upon secession, some Unionist delegates such as John S. Carlile called for immediate secession of the northwest from the commonwealth. He called together a mass convention at Clarksburg to advance that very idea. The only concrete issue decided there was to meet again in May at Wheeling to try and defeat ratification of the ordinance. When the voters decided to leave the Union, Wheeling's convention called for a second meeting in June. Waitman T. Willey and Francis H. Pierpont persuaded convention delegates to form a new loyal Virginia government before proceeding to the creation of a new state. ${ }^{13}$

Lincoln and his Cabinet quickly saw the emerging Restored Government of Virginia in Wheeling as a possible model for what would later be called Reconstruction. ${ }^{14}$ George W. Caldwell of Wellsburg urged Lincoln as early as April, 1861 to assist and protect the loyal government from Confederate Virginia once it assembled. ${ }^{15}$ Later, Attorney General Edward Bates discussed in a letter to A. F. Ritchie the position of Loyal

\footnotetext{
${ }^{13}$ Charles Ambler, ed. Debates and Proceedings of the First Constitutional Convention of West Virginia, 1861-1863 Volume I (Huntington, WV: Gentry Brothers, 1939), 8.

${ }^{14}$ Various names for the Commonwealth of Virginia government that remained loyal to the Union were "Reorganized", "Restored", and "Loyal” Government of Virginia. Its capital was first located in Wheeling, then later to Alexandria when Wheeling became the capital of West Virginia in 1863.

${ }^{15}$ George W. Caldwell to Abraham Lincoln, April 25, 1861, Abraham Lincoln Papers, Library of Congress, Washington D.C. http://memory.loc.gov/ammem/alhtml/malhome.html. Henceforth cited as "Lincoln Papers.”
} 
Virginia as a possible method of returning rebel regions to Union control. ${ }^{16}$ Subsequent developments proved problematic. Encouraging other Confederate states with sections seized by Union forces to create Union governments could be a sound idea but for the fact that the original model went ahead and dismembered the state. Most Confederate states, especially in the Appalachian Mountain region, experienced some degree of sectionalism before the war, with areas that felt neglected and treated as inferior much like western Virginia. ${ }^{17}$ Such issues could complicate a transition back to federal loyalty and control. Of course Lincoln also warned the Confederacy that they might expect parts of their union to mimic their behavior and try secession themselves. ${ }^{18}$ The secession of West Virginia from Virginia reduced Restored Virginia to a few counties and a regime with very limited jurisdiction, undermining Lincoln’s plans and perhaps altering the future of Reconstruction. ${ }^{19}$

Restored Virginia's creation represented the first step in breaking down the bonds between the people and the political system they understood while creating the group known in West Virginia history as “statemakers.” Historians often neglect the period between 1861 and 1863 in Wheeling, treating it with less than due significance. This era witnessed a surge not only of regional leaders, but also of men who may have never seen themselves as influential prior to the war. The Whiggish Willey served with other western notables such as diplomat and future Confederate officer Charles James Faulkner Sr. during the constitutional reform convention of 1850-51. The outbreak of the Civil

\footnotetext{
${ }^{16}$ Dallas Shaffer, “Lincoln and the 'Vast Question' of West Virginia,” 32 West Virginia History (January 1971), 86-100. Located at http://www.wvculture.org/history/journal_wvh/wvh/32-2.html

${ }^{17}$ John Alexander Williams, Appalachia (Chapel Hill: University of North Carolina Press, 2002), 159-161.

18 Abraham Lincoln Inaugural Speech 1861, Lincoln Papers, http://memory.loc.gov/ammem/alhtml/malhome.html.

${ }^{19}$ Dallas Shaffer, "Lincoln and the 'Vast Question’ ....", http://www.wvculture.org/history/journal_wvh/wvh32-2.html
} 
War counted him among the most prominent of the Unionist Virginians. Francis H. Pierpont, through his support of Abraham Lincoln in 1860, might have sacrificed any political ambitions he held, but the war made him Governor of Virginia. Thomas Carskadon, a young radical lawyer from western Hampshire (now Mineral) County, strongly opposed slavery and joined the Republican cause quite early. A man with such sentiments (a low ridge in Keyser where his mansion was built still honors his legacy through the name "Radical Hill") would have crashed his ambitions into the brick wall of Commonwealth conservatism had the war never started. Instead he developed into an influential voice among the early statemakers. The Civil War opened opportunities for many who might have otherwise remained outside of state level politics. West Virginia's statemakers who turned Republican did so in the context of war (and certainly many Democrats supported Restored Virginia and the creation o the new state as well.) Not all necessarily supported federal and state support for commercial and industrial development, especially if it increased the state debt. ${ }^{20}$

Part of the appeal of the Republican Party across the nation in the post Civil War decades lay in its vision of economic prosperity. When it preached a strong and believable vision of development, it spoke to the interests of voters and gained support. In the periods where people perceived that the party looked more to its own interests, it lost electoral support. Its economic vision was borrowed from Federalists and Whigs, then updated for the Second Industrial Revolution. Clay and Adams in the 1820s articulated an American style of commercial development undergirded by federal investment and encouragement. During Adams’ presidency, this translated into money for the construction of roads and canals while erecting a tariff to protect emerging U. S.

${ }^{20}$ Charles Ambler, ed. Debates and Porceedings, 37. 
manufacturers. Adams used the example of the Roman Empire. He stated in his inaugural address that "The magnificence and splendor of their [Rome’s] public works are among the imperishable glories of the ancient republics. The roads and aqueducts of Rome have been the admiration of all after ages.”21 Western Virginians in antebellum years yearned for more roads. After the war, many residents of the Mountain State put their faith in railroads and accompanying industry. ${ }^{22}$ They also desired other improvements, such as a free school system. Development that went hand in hand with widespread education would bring a more prosperous future. Many voters would eventually back the party that best implemented their economic and social goals.

Republicans dominated Congress after most Southern senators and representatives abandoned their posts and gravitated towards the Confederacy. Only Andrew Johnson remained to represent his Southern home, although Restored Virginia named new Unionist members. For the first time since the 1790s a party of commerce and industry held overwhelming control of the legislative and executive branches and it set to work creating an economic transformation. They raised tariffs and started encouraging the construction of the transcontinental railroad. Manufacturing expanded from an already powerful base. New York alone had more industry than Virginia, Alabama, Louisiana, and Mississippi combined. ${ }^{23}$

\footnotetext{
${ }^{21}$ John Quincy Adams, Inaugural Address. http://www.bartleby.com/124/pres22.html.

${ }^{22}$ Phillippi Republican, 31 January, 1884. A headline from that day's publication read "The Consummation of a Great Hope Realized." It continued by saying "Philippi Takes Her Place in History As a Railroad Town.”

${ }^{23}$ Paul Kennedy, The Rise and Fall of the Great Powers: Economic Change and Military Conflict From 1500 to 2000 (New York: Vintage Books, 1987), 180.
} 
The year 1864 saw Lincoln trying to weld into one movement loyal Democrats and moderate Republicans into a Union Party. ${ }^{24}$ May 1864 saw Republicans, War Democrats, and even some southerners supporting a convention platform of no compromises with rebellion and no tolerance for the continuation of slavery. ${ }^{25}$ This added Democrats to the already tenuous Republican alliance of interests. By 1864, Republicans divided strongly over the pace of emancipation, postwar treatment of the South, and the effectiveness of Lincoln's leadership. ${ }^{26}$ War Democrats had gravitated towards the Lincoln Administration since its beginning, most notably Secretary of War Edwin Stanton. Occasionally they had reservations about some of the Republican war measures. ${ }^{27}$ In retrospect, the Union Party movement succeeded politically in the short term because it brought war supporters of all stripes behind Lincoln. It never had a chance to survive in the long run because the postwar winds of change demolished this "big tent” movement. Too many differences separated Republicans from people like self-described “Union Conservative” Henry Gassaway Davis. ${ }^{28}$

Naturally, the Union Party movement pleased moderates and irritated some Radicals. Called "Unconditionals” in many states, these Radicals combined distaste for Lincoln's moderation, dislike of his political style, discontent over lack of access to patronage, and disavowal of any measures that seemed generous to the South. They wanted the South punished for the Civil War, not brought quickly back into normal

\footnotetext{
${ }^{24}$ George Denison to John G. Nicolay, March 22, 1864, Lincoln Papers, http://memory.loc.gov/ammem/alhtml/malhome.html.

${ }^{25}$ William Starr Myers, The Republican Party: A History (New York: The Century Company, 1928), 141.

${ }^{26}$ Stephen Oates, With Malice Towards None: A Life of Abraham Lincoln (New York: Harper Perennial, 1994), 381Some Republican congressmen called Lincoln "simple Susan" for his apparent hesitancy to approve what they considered to be necessary war measures.

${ }^{27}$ Chief Justice William Rehnquist, All the Laws But One: Civil Liberties in Wartime (New York: Vintage Books, 1998), 57, 72.

${ }^{28}$ Charles M. Pepper, The Life and Times of Henry Gassaway Davis (New York: Century, 1920), 36.
} 
relations with the federal government. William Lloyd Garrison, Wendell Phillips, Benjamin Wade, and Thaddeus Stevens were Radicals who initially supported the Union Party movement. So did Sumner, who seemingly never saw a president that he ever liked. ${ }^{29}$ This set the stage for the party warfare less than a decade later in that a group of Republicans remained irreconcilable to presidential leadership of the party. The Union Party movement also drove a wedge between Democrats that lasted well into the postwar era. Some Democratic Party faithful remained antagonistic to the changes brought by the Civil War. They also found it difficult to work with the "Union Democrats” who had remained loyal to the federal government, some of whom even joined Lincoln's Union movement.

Lincoln handled the different elements of his factionalized party with a deft skill matched by few over the next fifty years. All the factors in the various meltdowns of the Republican Party existed in 1864. Lincoln understood that finding an overall unifying theme while rewarding the loyal in all camps represented the key to holding together the Republican Party as originally constituted. He possessed the political subtlety of a Bismarck, and, luckily for Republicans, he was followed by a president in Andrew Johnson who also demonstrated the ability to unify much of the party on a single issue, albeit unwillingly and in a completely different way. One of the issues where Lincoln failed to create consensus was in the debate over admitting the new state of West Virginia.

Although Congress lent its approval to the Restored Commonwealth of Virginia when it seated its senators and representatives, questions remained about its status as a genuine state. Article four, section four of the United States Constitution requires that

\footnotetext{
${ }^{29}$ Myers, Republican Party: A History, 146.
} 
each state maintain a republican form of government. ${ }^{30}$ In Federalist 10 Madison implied that a republican form of government requires some kind of democratic process, although it is not a pure democracy. ${ }^{31}$ At first, Restored Virginia did not meet this standard. Its government consisted of self-appointed representatives from the western counties while its treasury contained money seized from a bank in Weston. Only after a state-sponsored election could Virginia meet the Madisonian standard. Critics, including Confederate President Jefferson Davis, claimed that Restored Virginia itself violated republican principles, claiming that the "State of Virginia was not a confederation, but a republic, a nation.” The Wheeling Convention called by Union-supporting Virginians he dismissed as "disorderly persons in the northwestern counties."32

In October 1861, the Restored government held a referendum on the dismemberment of Virginia and the voters who cast their ballots overwhelmingly supported the creation of a new state. Constitutionally, when a new state is formed within the boundaries of the existing state, it needs that state's permission. Only if Restored Virginia met the constitutional qualifications of statehood itself could it assent to West Virginia. Critics at the time and since have argued that since the majority of the people of Virginia did not assent to its creation, West Virginia's establishment was illegitimate. Jefferson Davis referred to it as "insurrection, revolution, and secession" as well as "the butchery of the mother of states." 33 Others assert that a majority had the opportunity to vote, but chose to not do so. In modern times, when election participation

\footnotetext{
${ }^{30}$ United States Constitution. Article IV Section 4.

${ }^{31}$ Alexander Hamilton, James Madison, John Jay, The Federalist Papers (New York: Mentor, 1999), 4551

${ }^{32}$ Jefferson Davis, The Rise and Fall of the Confederate Government Volume II (New York: D. Appleton, 1881), 256.

${ }^{33}$ Ibid., 257.
} 
occasionally falls as low as $30 \%$ of registered voters, it is difficult to accept an argument that claims that an election is invalidated because less than half of the registered voters approve.. Politically it does remain troublesome that most of the voters and officials who supported Restored Virginia later gravitated towards West Virginia. This forced Lincoln's hand. The president maintained all along that secession was illegal and that his war aim consisted of removing criminals from the Southern state capitals. Had the federal government not considered the October 24, 1861 election valid, it would have been forced to consider the Restored government a sham as well. This would have implied the legality of Virginia's secession. Moreover, Lincoln hoped to use Restored Virginia as a model to reconstruct other states. ${ }^{34}$ Lincoln feared greatly that responsible individuals inside and outside the United States would see secession as legal and consider the Confederacy a real sovereign nation.

Many considered West Virginia’s creation vital. Archibald Campbell, editor of the Wheeling Intelligencer, explained in a letter to Lincoln that "In the present prospects of our national affairs the expectation of a new state keeps thousands from falling away... Destroy the hope of a new state and our people see themselves remanded again to Eastern Va \& again identified and committed to her fortunes. A crushed minority sentiment, thoroughly disloyal, would soon warm into life. ${ }^{\text {,35 }}$ Campbell's letter indicated that Union sentiment relied strongly on the hope that a new state government offered protection regardless of the outcome of the war. Even a Union victory did not guarantee that the Wheeling government's participants would always be safe.

\footnotetext{
${ }^{34}$ James McPherson, The Battle Cry of Freedom (New York: Oxford University Press, 2003), 244.

${ }^{35}$ Archibald Campbell to Abraham Lincoln, December 31, 1862, Lincoln Papers, http://memory.loc.gov/ammem/alhtml/malhome.html.
} 
The creation of West Virginia illustrated some of the issues dividing congressional Republicans. Radicals opposed any sort of compromise with slavery, but West Virginia's statemakers refused to immediately outlaw the practice. Charles Sumner and other Radicals expressed dismay at the deference demonstrated towards an institution they intended to destroy. Sumner stated that "my vote shall help no new State to take a place in this Union, with Senators in this body unless purged of this poison.,36 Fault lines over West Virginia statehood once again revealed the differences between the party factions that later battled for control of the Republican Party later on. The debate in Congress even before the statehood bill reached the desk of Lincoln centered around the existence of slavery in the future state. Senator Willey struggled to find grounds for compromise that most could at least accept. An extension of the Willey Amendment provisions proposed by James Henry Lane provided that child slaves would become free by their $21^{\text {st }}$ birthday. This outraged the most zealous opponents and defenders of slavery. Sumner led a handful of Radicals to oppose it while Virginia Senator John Carlile objected to any attack on slaveowners' rights. Attacks from both sides of the slave issue failed to defeat the measure and the bill hit the president's desk late that month. ${ }^{37}$ The decision to create a new state, from Lincoln's point of view, came from considerations of war. Lincoln wrote that "More than on anything else, it [West Virginia statehood] depends upon whether the admission or rejection of the new State would under all the circumstances tend the more strongly to the restoration of the national

\footnotetext{
${ }^{36}$ Charles Sumner, Charles Sumner: His Complete Works Volume IX (Boston: Lee and Shepherd, 1900), 122.

${ }^{37}$ John Alexander Williams, West Virginia: A History, 76, 78.
} 
authority throughout the Union..38 Campbell appealed to Lincoln as a Republican supporter, but Lincoln saw the state's creation as a war measure. West Virginia, in modern terms, was a psychological operation, an "irrevocable encroachment on the cause of rebellion.”39 Lincoln intended to bolster Unionism and discourage Confederate Virginia.

America's Civil War changed more than just the political landscape of West Virginia. While representatives of the various counties debated and formulated first the Restored Government of Virginia, then the new State of West Virginia, the people of the region suffered tremendously. Even the leaders themselves experienced a glimpse of the fear and terror that gripped the region. Thomas Carskadon of New Creek in Hampshire, later Mineral, County complained in spring of 1862 "I have not dared to go home since the adjournment of the convention though boarding 10 miles off." He added that pleas for assistance sent to local military leaders resulted in no help. ${ }^{40}$ Indeed the New Creek Valley experienced more destruction and privation, not less, within the following two years.

The old Virginia authority system based upon county courts dominated by families and cliques suffered most during the war. Any local leader identifying with the Confederate side received the tarnish of treason. The county court system itself became a subject of debate in the new state constitution. Abraham Soper, a prewar "Douglas Democrat” representing Tyler County in the West Virginia Constitutional Convention, proclaimed "I have nothing to say against the county court." He added that "Many of

\footnotetext{
${ }^{38}$ Abraham Lincoln, “Memorandum on West Virginia,” December 31, 1862, Lincoln Papers, http://memory.loc.gov/ammem/alhtml/malhome.html.

${ }^{39}$ Abraham Lincoln, “Opinion on West Virginia Statehood,” December 31, 1862, Lincoln Papers, http://memory.loc.gov/ammem/alhtml/malhome.html.

$\frac{40}{40}$ Thomas Carskadon to Waitman T. Willey, March 1862, Willey Papers.
} 
them are very competent, respectable men in the performance of their duties.”41 Peter van Winkle disagreed, maintaining that "the old county system is repudiated" by the "feelings and wishes of our constituents." The county court, according to its detractors, resulted in an "evil” blending of its original judicial functions with those akin to a legislature.

West Virginia’s constitutional convention's solution lay in altering many of the governmental functions of counties, such as authority over schools and roads, and vesting them in newly created townships. ${ }^{42}$ Although Van Winkle accused some of leaning towards the ways of old Virginia by "hankering after the fleshpots of Egypt," he did not hesitate to borrow Jeffersonian political advice when it suited him, in this case reminding delegates that Jefferson called for counties to be subdivided into wards in the manner of "the hundreds of Saxon Alfred."43 Gordon Battelle argued that over twenty million people currently lived under township government in the United States. ${ }^{44}$ Some did not oppose the concept of subdividing counties, but objected to the word "township" because of its "Yankee” origin. Some preferred “parish” because of its use in Virginia at one time, but others disagreed on account of the word's ecclesiastical origins. ${ }^{45}$ Eventually the name "township" grew acceptable. It represented one of the key changes of the statemakers to transform local government in West Virginia. Even the choice of words could produce intense debates. Not only would the remainder of the power enjoyed by

\footnotetext{
${ }^{41}$ Charles Ambler ed. Debates and Proceedings of the First Constitutional Convention of West Virginia: 1861-1863 Volume II, 497.

${ }^{42}$ Ibid, 438-440.

43 "Hankering after the fleshpots of Egypt" was a favorite reference of western Virginians. It served as an accusation of being too attracted to the traditions of Confederate Virginia.

${ }^{44}$ Ibid, 459.

${ }^{45}$ Ibid, 455-456.
} 
the old dominant families be further undercut, but township government opened opportunities on the local level to some of the emerging elites.

The debate over counties extended to how many to include in the new state. The area north of the Kanawha and Teays Valleys and west of the Allegheny Front seemed safely Union. ${ }^{46}$ Historically the addition of hostile populations has caused political leaders concern when one of their primary functions lies in maintaining some level of social order. Henry Dering explained that "I, for one, am not willing to embrace any people in the bonds of our new state who do not desire to come with us.” Dering pointed out that "the presumption is a fair one that in these counties are a great many rebels.",47 Including these counties brought forth powerful opposition from others as well. Preston County’s John Brown literally warned of “counterrevolution” as a result of adding "unsound" counties. Many delegates understood that a democratic form of government would emerge in a postwar West Virginia. Interestingly, Brown used the phrase “defensible boundaries” which indicated a possible lack of faith that the Union would eventually win. ${ }^{48}$ In such a situation a state ruled by Confederate sympathizers could opt to leave the Union and rejoin Virginia. Although Republicans in Congress desired a larger West Virginia to create a wider expanse of certain Union control (especially in the case of a Southern victory, an aspect of these machinations often forgotten in modern

\footnotetext{
${ }^{46}$ One of the great "spin" victories of the Civil War lay in the increasing equivocation between the concepts of "Union" and "Republican." This came to fruition in the campaign of 1864 where Republicans and War Democrats formed the National Union Party. Meanwhile Democrats increasingly suffered from their party's identification with rebellion and treason as is exemplified by the literal "waving of the bloody shirt" by Republicans in postwar political campaigns.

${ }^{47}$ Ambler, Debates and Proceedings I, 223-224.

${ }^{48}$ Ibid, 274-276.
} 
times), Copperhead Democrats also supported the inclusion of these counties because of the likelihood of making West Virginia an eventual Democratic Party stronghold. ${ }^{49}$ Within the convention, Union Democrat Daniel Lamb countered with the argument that the counties to the south and east were "naturally part of Western Virginia." He asked if the delegates proposed "to abandon the scheme of instituting the new state because the people of Calhoun County say they are unwilling to come in.” The delegates already included Nicholas and Fayette, despite known opposition. ${ }^{50}$ Lewis Ruffner of Kanawha County questioned how the opinion of any county under Confederate control could be ascertained, and Thomas Carskadon argued that knowing the questioned county's public opinion did not matter in terms of "the spirit of the ordinance." ${ }^{51}$ Others pointed out that the counties in dispute represented "garden spots of western Virginia for wealth and the revenues that flow out of that wealth should necessarily flow into the treasury of West Virginia." ${ }^{\text {52 }}$ Eventually the state included an extended arm of counties bordering the Allegheny Front and the Potomac River for the purpose of keeping the $\mathrm{B} \& \mathrm{O}$ in the jurisdiction of a friendly government. As the war wound down, state leaders increasingly felt pressure to deal with the consequences of that inclusion.

The potential name of the new state revealed strong attitudes about the opinions of its leaders. Originally the name "Kanawha” incurred general agreement. This name reflected a pragmatic desire to help wed a doubtful, yet potentially important region to the Pittsburgh-influenced northwest. One delegate argued "I am a Virginian; I was born

\footnotetext{
${ }^{49}$ Richard Brisbin, et al. West Virginia Politics and Government (Lincoln NE: University of Nebraska, 1996), 19.

${ }^{50}$ Ambler, Debates and Proceedings I, 280-281.

${ }^{51}$ Ibid, 229-230.

${ }^{52}$ Ibid., 227.
} 
and raised in Virginia and I have ever been proud of that name.” Others referred to the ancient lineage of the name in reference to Elizabeth I and the Virgin Mary. ${ }^{53}$ Jettisoning Kanawha in favor of West Virginia revealed a reluctance to abandon all of the area's past and tradition while also acknowledging the power that the Virginia ideal still held over many of these men. Sentiment for the Old Dominion inspired real fear among some of the state constitutional convention delegates about the permanence of their endeavor. Peter van Winkle believed that "several gentlemen intend to be Virginians after we have separated from Virginia." Van Winkle added that he hoped the idea that "they did not do so in Old Virginia” would not form an impediment to developing the new state.

The statemakers in Wheeling could not simply debate from their podiums in Ohio County, but also found ways to extend their influence into their jurisdiction. Simply by doing their jobs, West Virginia’s new leaders solidify the perception of the new state's existence. As the war continued, Senator Waitman T. Willey’s correspondence contained more practical questions about governance and business. Prior to the war, Willey had served the Whig Party with a special emphasis on the temperance movement. He made his name speaking to huge crowds and was well known in Virginia, Ohio, and elsewhere. The Civil War saw him become a strong opponent of secession and, with some reluctance, a supporter of the new state of West Virginia which he would serve in the U.S. Senate. Along the way he joined the Republican Party. While he did not become the most influential leader in that party, Willey did serve in a position of prominence during the early history of the state.

This Morgantown lawyer served as one example of an authority figure that would have to help establish trust in the new state. He was part of the process that established ${ }^{53}$ Ibid, 81. 
West Virginia as a permanent entity that could perform all the usual, mundane functions of government. Willey answered questions about how to do business in West Virginia. One minister needed to know if his license to perform marriages in Virginia was valid in the new state. ${ }^{54}$ An out of state resident with a farm near Romney asked about the possible disposition of his slaves. He understood that emancipation would come, but wondered about compensation. ${ }^{55}$ A small group of citizens in January of 1863 held valid concerns about an election that would send West Virginia's first congressmen to Washington. They wanted copies of the governor's proclamation about the election and information about the location of polling places. They also asked who would receive the votes and judge their legality, and finally enquired as to whether citizens could select their own election officials in the absence of regular authorities. ${ }^{56}$ According to one historian, the “'middle class, law and order, well-behaved folks' they seem to have gone with the prevailing authority, as law and order people usually do., ${ }^{\text {57 }}$

This does not reflect the distinct possibility that formerly "well-behaved folks" might have shed their law and order demeanor given a stressful circumstance. A Harrison County man who reported on the activities of a military occupation official to Senator Willey serves as an example. The Union officer was accused of taking property and gambling while administering the occupation near Clarksburg. ${ }^{58}$ Writing one’s congressman to express a grievance represents almost quintessential middle and upper class values in America. People with trust in a civil society believe that senators and

\footnotetext{
${ }^{54}$ S.H. Proofe to Willey, April 6, 1864, Willey Papers

${ }^{55}$ A. Holland to Willey, April 6, 1864, Willey Papers.

${ }^{56}$ Pete Rosenburg et al. to Willey, January 9, 1863, Willey Papers.

${ }^{57}$ Williams, West Virginia: A History, 84.

${ }^{58}$ J. W. Wilson to Waitman T. Willey, December 1861, Willey Papers. In Lieb’s defense, General Benjamin F. Kelley wrote that he was a "man of great energy." Benjamin F. Kelley to Waitman T, Willey, February 6, 1862.
} 
representatives want to make circumstances better for their constituents. Of course the letter also carried an implied threat to the well-being of the officer, normally an action that lies outside acceptable bounds of civil society. This specific officer also represented the most direct prevailing authority in Harrison County and apparently not all of the fine folks undertook to submit to it cheerfully. That being said, the state of West Virginia could not have survived without the acquiescence of a large number of people to its existence. The same goes for the Republican Party which increasingly dominated the early state government.

Not everyone peacefully accepted the dramatic changes taking place. West Virginia eventually absorbed counties in the east and the south that had not shown enthusiasm for inclusion. By 1864 the Republican Party, temporarily calling itself and its allies the "National Union Party," looked to consolidate its hold in West Virginia. Willey himself received numerous invitations to speak to "Friends of Lincoln" or "Friends of Lincoln and Johnson” rallies. In contrast to modern politics when national figures often come to stump for candidates for Congress, Willey became a foot soldier in the cause of Lincoln's reelection. Supporters of Lincoln counted on the idea that Willey had grown into a man the people trusted. However, despite the often pessimistic Preston County Reverend John Drummond who wrote in the fall of 1864 "the McClellanites show more strength here than was expected,” Lincoln did carry the state. ${ }^{59}$

According to John Alexander Williams, conditions forced the statemakers "to proceed in arbitrary, undemocratic ways” despite the effort to ground the state's system in republican and democratic principles. ${ }^{60}$ Such measures reassured Republican

\footnotetext{
59 J. Drummond to Willey, October 13, 1864, Willey Papers.

${ }^{60}$ Williams, West Virginia, 85.
} 
statemakers, but created the context of bitter rhetoric and campaigning between the parties for the next twenty years or more. Governor Arthur I. Boreman wielded the sword and the shield of West Virginia in its initial years as a state. To modern minds, Boreman appeared almost dictatorial. Before rendering judgment on the governor, one must understand his position. The chief magistrate of any government must, first of all, defend his state and enforce its laws. In the context of the Civil War, Governor Boreman followed the model of President Lincoln who would not allow the nation to fracture into oblivion to protect certain rights. The inclusion of the more Confederate leaning counties formed a danger to Republican Party control and the state’s existence. To Boreman, Republican Party control was all that ensured the continued existence of West Virginia. Especially as hostilities ceased, Governor Boreman and state Republican leaders believed strongly that returning ex-Confederates could tip the electoral balance into the Democratic column. Randall Scott Gooden’s dissertation indicates that Boreman also feared the effects of Andrew Johnson's Reconstruction policies and creatively used states' rights arguments to attack the president's pardon power. ${ }^{61}$ The Governor had to take steps, as far as he was concerned, to protect his fledgling state.

West Virginia emerged from its Civil War experience intact. It had a strong governor assuming vast powers to protect the state and direct its development. West Virginia broke radically from its Old Dominion past. This sharp movement towards northern style government combined with the harsh proscriptions against former Confederates gave those opposing the original Constitution issues to rally around. In Boreman's inaugural address of June 20,1863, he called for "the indulgence of a

\footnotetext{
${ }^{61}$ Randall Scott Gooden, "The Completion of a Revolution: West Virginia From Statehood Through Reconstruction” (Ph.D diss., West Virginia University, Morgantown, 1995), 59.
} 
generous constituency.” His first major point justified the movement of West Virginia towards independence. Citing "unfairness and inequality of legislation" he described the perceived neglect by the eastern oriented government. Then he argued "there has been little intercourse between" the peoples of the east and west. ${ }^{62}$ Although some historians such as Ron Eller have built upon that theme, others such as Ronald Lewis maintained that commerce and economic ties historically linked at least some of these areas to eastern Virginia. ${ }^{63}$ Certainly commerce on the Potomac as well as the Northwestern and James River and Kanawha turnpikes linked parts of Trans-Allegheny Virginia to the eastern region. However Boreman stated that "the mountains intervene between us, the rivers rise in the mountains and run towards the northwest." ${ }^{\text {,64 }}$ The governor's argument certainly helped to defend the creation of the state itself, although not necessarily the inclusion of the eastern panhandle.

Next, Boreman set up the strict measures his administration eventually utilized by condemning the rebellion. The Confederacy was "like the poisonous fruit of the Upas tree that blights and withers everything that comes within its influence" and was "fraught with evil. ${ }^{65}$ He blamed Confederate leaders for spreading malicious alarm about the election of Abraham Lincoln "by fraud and by falsehood" and fooling the people of the South into taking up arms. The people of Trans-Allegheny Virginia, however, "took our position with our eyes open.” That did not protect the people from being "invaded by

\footnotetext{
${ }^{62}$ Arthur I. Boreman, “Inaugural Address of Arthur I. Boreman,” West Virginia Division of Culture and History, http://www.wvculture.org/history/boremania.html

${ }^{63}$ Ronald Lewis, Transforming the Appalachian Countryside (Chapel Hill: University of North Carolina Press, 1998), 20.

${ }^{64}$ Ibid.

${ }^{65}$ The Upas tree was a literary allusion utilized by Romantic and Victorian Era writers. It grows along the basin of the Indian Ocean northward into China and produces a highly poisonous latex. One legendary but untrue European account from the 1700s stated that animal life cannot survive within fifteen miles of the tree.
} 
traitors ... [that] applied the torch to public and private property; they have murdered our friends; they have robbed and plundered our people; our country is laid waste, and to-day gaunt hunger stares many families of helpless women and children in the face." ${ }^{, 66}$ This statement, that doubtless inspired tremendous outrage, should not be seen as simply calculation. Boreman very likely spoke his convictions and emotions here. All too often statesmen get too much credit for Machiavellianism in their motivation for giving addresses. Here West Virginia's governor did not create the hatred but tapped into it, not only in the souls of the audience, but also most likely himself.

The inaugural address helped to create "the enemy." On one hand, the Confederate States obviously represented an enemy. Loyal citizens receive instructions to remain vigilant and purge undesirables. Also, the population must believe in the existence of the enemy. A leader cannot simply pull the strings of the people, they must already have an idea that their society faces threats. It did not take much to convince the Unionists of West Virginia that rebels bore them ill will. The animosity that lingered after the war, particularly in areas touched most by it, mobilized both Union and Confederate veterans and supporters politically. ${ }^{67}$

Boreman hinted at what measures the state would take to protect its existence. He blasted those that continued to "carp and cavail at everything that is done by the administration in Washington to put down the rebellion," agreeing specifically with Lincoln's occasional suspensions of habeas corpus. Boreman maintained that ceasing the war meant submission to the Confederacy, which loomed as a real possibility in West

\footnotetext{
${ }^{66}$ Arthur I. Boreman, “Inaugural Address of Arthur I. Boreman,” West Virginia Division of Culture and History, http://www.wvculture.org/history/boremania.html

${ }^{67}$ Mark Wahlgren Summers, The Gilded Age: or The Hazard of New Functions (Upper Saddle River NJ: Prentice Hall 1997), 50-51.
} 
Virginia. According to Confederate Virginia, West Virginia statemakers had committed treason and John Brown's fate illustrated what lay ahead in the case of defeat. West Virginia’s inclusion of several counties that had overwhelmingly supported the Confederacy meant that threats would emerge against the Unionist power structure. According to John Edmund Stealey, Jefferson County sent sixteen percent of its population to fight for the South. After West Virginia introduced proscriptive measures against former Confederates, only forty-three out of 1,500 in the county seat were eligible to vote. ${ }^{68}$

Finally, Boreman proposed a new path for the new state. Destruction of the "old regime" with all the violence and chaos that attends such actions requires that the new government offer positive change to legitimize itself. Boreman proposed a new economic plan that promised significant changes from the prewar agrarian economy, advocating for the advancement of industry in West Virginia. Unlike Republican political power or the northern-influenced constitution crafted during the war, this proved to be the heart of the transformation of West Virginia in the $19^{\text {th }}$ and $20^{\text {th }}$ century. The Second Industrial Revolution completely altered the landscape as well as the society. It wrenched county governments from the seats originally established into towns more convenient to business interests. Significant benefits accrued to the people, but so did growing pains, environmental damage, and other problems. A tremendous influx of capital investment and societal change poured into West Virginia between the end of the Civil War and World War I. Many of the statemakers believed that the new industrial economy needed an educated population. Governor Boreman's inaugural address

\footnotetext{
${ }^{68}$ John Edmund Stealey III, “The Freedman’s Bureau in West Virginia”, 39 West Virginia History (January-April 1978): 104.
} 
promised that "it shall be my especial pride and pleasure to assist in the establishment of an education system throughout the state that may give to every child among us, whether rich or poor, an education that may fit for them respectable positions in society.”99

Some debate the origin of these postwar aspirations described by Governor Boreman. Ken Fones-Wolf has argued that the priorities of the statemakers reflected the social goals of Wheeling residents and leaders. Wheeling supported modernization, which to them meant protection of industry and expansion of railroads, as well as public education. ${ }^{70}$ Northwestern Virginians prior to the Civil War pushed strongly for free schools. Delegate Robert Hagar of Boone County complained that a "large quantity of native ability" was present in the western counties but could not thrive due to the "almost complete absence of schools. ${ }^{, 71}$

Like the rest of the country, West Virginia benefited from the Morrill Act that helped to establish colleges and universities in each state. By 1867 West Virginia used federal funds to establish the "Agricultural College of West Virginia” later renamed West Virginia University. ${ }^{72}$ However the primary commitment to education for early Republicans and their allies lay in the creation of a free public school system. The Constitution of 1863 required that the "Legislature shall adopt as soon as practicable for the establishment of a thorough and efficient system of free schools., ${ }^{, 73}$ The subsequent 1872 Constitution mirrored this commitment. Prewar Virginia originally established a system of free public schools due to the interest demonstrated by Thomas Jefferson.

\footnotetext{
${ }^{69}$ Arthur I Boreman Inaugural Address, http://www.wvculture.org/history/boremania.html

${ }^{70}$ Ken Fones-Wolf, “A House Re-Divided: From Sectionalism to Political Economy in Post-Emancipation West Virginia" in Reconstructing Appalachia: The Civil War's Aftermath, ed. Andrew L. Slap (Lexington: University Press of Kentucky, 2010), 237-268.

${ }^{71}$ Ambler, Debates and Proceedings IV, 33, 34.

${ }^{72}$ Charles Ambler, West Virginia: The Mountain State (New York: Prentice Hall, 1940)447.

${ }^{73}$ Goodspeed Brothers, A Reminiscent History of Northern West Virginia (Chicago: Goodspeed, 1895), 43.
} 
Funding cuts in 1817 forced many to start paying tuition to attend school in very rudimentary structures. Illiteracy in such conditions actually increased in the 1830s. ${ }^{74}$

The legislative acts creating the free school system passed in 1864 and the state appointed William R. White to direct implementation. Within one year twenty counties had full school systems and eleven more had partially met the requirements. Almost 16,000 children attended 431 schools. Despite opposition in some regions to the concept, most West Virginians remained "friendly to the free public school." Each township had its own board of education while superintendents presided over counties. By 1866 over 34,000 students received a free education. ${ }^{75}$ White also successfully advocated for the establishment of teacher training facilities. By the 1870s, six normal schools trained teachers for the state school system. In 1872, Governor William Stevenson proudly stated of free education that "it now may be regarded as part of our fixed policy and rightly so." ${ }^{, 76}$ Advocates saw free education as a way to save children "from a life of infamy” as a New York City Board of Education president explained in $1865 .{ }^{77}$ This sense of purpose dovetailed with federal policy represented briefly in West Virginia by the Freedman’s Bureau. It operated in the state until 1868 so its effect remained limited, but it did succeed in helping West Virginia create a system of schools for black children. State Superintendent of Schools and Methodist minister William Ryland White argued that "if a common school education is necessary to make a good citizen of a white, may surely it is equally necessary in the case of the black..78 Participation in the

\footnotetext{
${ }^{74}$ Charles Ambler, West Virginia: The Mountain State, 276.

${ }_{75}^{75}$ Ibid, 444. Also A Reminiscent History of Northern West Virginia, 44.

${ }^{76}$ Ibid, 415.

${ }^{77}$ New York Times, February 9, 1865.

${ }^{78}$ Stealey, “The Freedman's Bureau in West Virginia”, 114.
} 
establishment of these schools varied from initial hostility in Jefferson County to sullen acceptance in the Kanawha Valley to relatively good support in other areas. ${ }^{79}$

In addition to the state university, teaching institutions, and free schools, West Virginia before 1872 also established a penitentiary, insane asylum, and facility to teach sensory deprived children. Historian Charles Ambler explained that state traditions allege that Moundsville preferred getting the prison over the state university, although the fact that a suitable structure already existed may have helped state officials to locate the penitentiary there. He also claimed that prison officials "have been politically acceptable to the dominant party." ${ }^{80}$ These new institutions provided sources of patronage for Republicans as they tried to sink roots into the West Virginia political system.

A major influence on the early development of West Virginia and that state's Republican movement lay in the Methodist Episcopalian Church. Although statemakers did come from other denominations, Methodist influences have been cited by historians. Statemakers Senator Willey, Thomas Carskadon, Abijiah Dolly of Grant County, Boone County's Robert Hagar, and many others worshipped in that faith. Many of the Methodists had served in the abolitionist or temperance causes prior to the war and zealously pressured the state to advance public education. Gordon Battelle, Hagar, and Upshur County’s Richard Locke Brooks (a descendent of John Locke), among others, served as ministers. Battelle served as the chair of the committee on education during the formation of the original state constitution. They saw public education originally as a

\footnotetext{
${ }^{79}$ Ibid, 112, 125.

${ }^{80}$ A Reminiscent History of Northern West Virginia, 449.
} 
means to not only improve the knowledge and character of children, but also to teach them how to defend the state. ${ }^{81}$

As with other changes this took place within a national context. Railroad development expanded tremendously in the North before the Civil War. West Virginia attempted to catch up in the decades following peace. Investment in mining and manufacturing during the Civil War rose considerably in the northern states and continued in the 1870s and 1880s despite an overall economic depression. Protective tariffs prevented foreign competition in coal production. Another extremely important emerging influence in West Virginia lay in industrialists and their faith that development could enrich their region as well as themselves. According to John Alexander Williams:

An important premise of the men who founded West Virginia was that political autonomy, coupled with the 'boundless resources' locked in the West Virginia hills, would guarantee a future as rich as could be found in any other American commonwealth. $^{82}$

Arthur I. Boreman, Union Democrat and future U.S. Senator Henry Gassaway Davis, and their contemporaries likely would not argue with Ken Fones-Wolf and Ronald Lewis’s assertion that "resource extraction has become synonymous with the state's capitalist transformation.”83 Many in western Virginia before the conflict shared the belief that Richmond intentionally held back economic development. They additionally held a faith that development equaled progress. Peter van Winkle served as president of the

\footnotetext{
${ }^{81}$ Ambler, Debates and Proceedings Vol. I, 69.

${ }^{82}$ John Alexander Williams, West Virginia and the Captains of Industry (Morgantown: West Virginia University Library, 1976), 2.

${ }^{83}$ Ken Fones-Wolf and Ronald Lewis, Transnational West Virginia: Ethnic Communities and Economic Change, 1840-1940 (Morgantown: West Virginia University Press, 2002.), xi.
} 
Northwestern Virginia Railroad for a time. He shared with Davis a strong belief in the power of railroads to access resources and develop the region. Economic development directly benefited industrialists, but also stood to satisfy the needs of other professions, such as the law. Lawyers had never existed in short supply in West Virginia prior to separation. They served as a large pool from which state leadership emerged.

Ronald Lewis argues that many of the most influential statemaker Republicans shrank from fully pursuing large scale industrialism. They supported some manufacturing and farming, but did not entirely embrace the idea of full scale industrialization. Historian Oscar Doane Lambert noted that the Legislature chartered a large number of oil companies, turnpike and bridge building firms, and lumber companies during the 1860 s. ${ }^{84}$ Many switched from the Democracy and Whiggery to the new Republican Party to take part in building a new state and influencing its direction. ${ }^{85}$ Others followed the lead of Henry Gassaway Davis and left the Union movement to return to the Democratic Party, taking their development ideals with them. Republicans between the Civil War and the 1870s did not oppose investment and development, but concerned themselves more with consolidating their party position and serving existing constituents. ${ }^{86}$ The 1870s saw the regular factions of both major parties supporting industrial development; this represented the most striking change to occur within West Virginia in the 1860s. West Virginia and the United States as a whole experienced a continuing evolution of problems throughout the Civil War into the Reconstruction period.

\footnotetext{
${ }^{84}$ Oscar Doane Lambert, West Virginia and its Government (Boston: D. C. Heath, 1951), 146.

${ }^{85}$ Ronald Lewis, Transforming the Appalachian Countryside (Chapel Hill: University of North Carolina, 1998), 56.

${ }^{86}$ Ibid., 243
} 
Education and economic development formed a large part of the positive vision that Republicans sought to bring to the state. Many remained fearful that whatever forward movement occurred might be erased by a Democratic "Redeemer" government that would restore antebellum conditions as much as possible, or even return the state to Virginia. Former Confederates returning from the war potentially had voting strength in the eastern and southern sections of the state. The first generation of Republican Party and other Unionist movement leaders in West Virginia maintained an iron watch over the affairs of their new state. Nothing rankled the defeated Confederates and the Democratic Party in West Virginia more than the "voters' test oath" implemented on February 25, 1865. Any voter coming to the polls faced the possibility of a challenge from any other citizen. Upon hearing the challenge, the individual had to affirm by oath that he had not taken up arms voluntarily against the United States, the Restored Government of Virginia, or West Virginia. Additionally he had to promise that he never held any office in any government hostile to the aforementioned entities and that he without reservation supported the United States and the Constitution of West Virginia. Citizens who failed to serve in the armed forces of the United States and also failed to recite the oath could find themselves at odds when seeking government positions or justice in the courts. For example, voters in the Ninth Judicial Circuit selected Samuel Price of Greenbrier County. The elected judge could not take office because he could not recite the test oath in honesty or conscience. ${ }^{87}$ The law tightened in 1866 , forcing all attorneys to recite the test oath upon challenge. Charles J. Faulkner Sr., former diplomat and staunch Confederate, refused the oath and did not return to the bar for some time. ${ }^{88}$ In 1867 , boards of

\footnotetext{
${ }^{87}$ Otis Rice, A History of Greenbrier County (Lewisburg: Greenbrier Historical Society, 1986), 302.

${ }^{88}$ William Thomas Doherty, Berkeley County USA (Parsons: McLean, 1972), 168.
} 
registration appeared to enforce the oath upon voters, often going well beyond their stated powers in removing suspect names from the rolls. ${ }^{89}$ Every township had its own registrar. West Virginia Attorney General A. B. Caldwell instructed Governor William E. Stevenson (who was pragmatically edging away from a hard line against former Confederates) in 1870 that "It matters not what oath an applicant offers to take, he should not be registered unless the registrar and board of registration are satisfied."90 Gooden argued that these actions encouraged the cooperation of Union Democrats and former Confederates. ${ }^{91}$

By the late 1860s the atmosphere across the state and nation warmed towards former Confederates as most realized they could not be forever kept in citizenship limbo. Post-Civil War challenges to the practice of test oaths moved slowly through the federal court system. In another border state, Missouri’s Unionist government created an oath featuring over thirty disavowals, including one that asserted that the speaker never acted or spoke in favor of anti-federal individuals or groups. Eventually the Supreme Court heard the case and decided against the Missouri oath, finding that it was a "bill of attainder” and an "ex post facto law.” The Constitution prohibited both practices whether enacted by the federal or the state governments. Citizens could not be punished for actions without trial nor held in violation of the law passed after the fact. ${ }^{92}$ Supreme Court action combined with public sentiment likely fueled the "let up” movement that attracted more West Virginia Unionists as the new decade commenced.

${ }^{89}$ John Alexander Williams, West Virginia: A History, 89.

${ }^{90}$ A. B. Caldwell to William Stevenson, July 18, 1870, Nathan Goff Papers, West Virginia and Regional History Collection, West Virginia University, Morgantown, West Virginia. Hereafter referred to as "Goff Papers.” Also included in Alston Gordon Dayton Papers, West Virginia and Regional History Collection, West Virginia University, Morgantown West Virginia.

${ }^{91}$ Gooden, "The Completion of a Revolution," 61.

${ }^{92}$ Chief Justice William Rehnquist, The Supreme Court (New York: Alfred Knopf, 2004), 82. 
West Virginia’s let up Republicans had two goals. They wanted to return Confederates to the polls while passing an act to allow black suffrage (a moot act due to passage of the Fifteenth Amendment.) The Wheeling Intelligencer saw the expansion of citizenship rights to both parties as "judicious" and "necessary."93 Some Republicans, such as Stevenson, were bowing to reality rather than conviction when supporting changes in the laws. Democratic Party leader Charles J. Faulkner Sr. expressed his personal appreciation to the Intelligencer for its "attitude on the subject of disabilities" and claimed that articles on the subject of Confederate citizenship disabilities "exhibits statesmanship and political sagacity.” Faulkner even pledged to assist two Republicans in their House of Delegates campaigns. ${ }^{94}$

At the time, some Republicans saw the return of Confederates to the franchise as a way to broaden the base and secure a majority when the inevitable return of thousands of Democratic voters occurred. Fear of their potential power formed part of the reason for the postwar stripping of their citizenship rights. ${ }^{95}$ The gamble failed as the issue of rebel voting, in part, split the party. Emerging Republicans, such as Nathan Goff (Andrew Johnson's appointee to the office of United States District Attorney), challenged the authority of the statemakers. The year 1870 ended in disaster for the party. One major newspaper lamented that defeat came from an unenlightened viewpoint on black suffrage, "the so-called liberal movement, and personal ambition."96 The West Virginia Republican Party's chances to retain power diminished greatly after 1871. Former

\footnotetext{
${ }^{93}$ New York Times, April 24, 1871.

${ }^{94}$ Charles J. Faulkner Sr. to Granville Davisson Hall, June 24, 1869, Granville Davisson Hall Papers, West Virginia and Regional History Collection, West Virginia University, Morgantown, West Virginia. Afterwards referred to as "Hall Papers."

${ }^{95}$ Disabilities were considered necessary for protecting "the loyal people and government in this state against the domination of traitors.” Granville Davisson Hall to General R. S. Northcott, June 26, 1866, Hall Papers.

${ }^{96}$ Parkersburg State Journal, November 3, 1870.
} 
Confederates returning to political life meant that the constitution created in 1863 had very little time remaining. Democrats swarmed the polls to vote against the victors from six years prior, sweeping the statemakers from office and commencing the Bourbon age in West Virginia politics. ${ }^{97}$ A Democratic Party barely able to hold itself in one piece unified its efforts to kill off the hated "Yankee" Constitution of 1863 as its first order of business.

Crafting a constitution influenced more by northeastern states than the Old Dominion was, after the creation of the state itself, the primary achievement of the mostly Republican statemakers. Democrats grew to appreciate the opportunities available with the new state, but still despised the northern influenced system created by the statemakers, so the Constitution of 1863 fell under threat. Measures originally seen as necessary to defend the state itself appeared more tyrannical when the object lay in protecting a set of laws from the (possible) majority of the voters. West Virginia's chief executives before 1872 faced an interesting problem. They took an oath of office that required them to defend the constitution, but by the early 1870s a large section of the electorate sought to eliminate the basic legal structure of state government.

The return of the Democratic Party into power in West Virginia followed a Southern and border state pattern. Clearly one must not consider West Virginia an officially reconstructed state since its own government applied all the prohibitions with minimal federal intervention. Like other border states, it suffered through the problem of what to do with ex-rebels and had to start making choices about its economic development. Bourbon style regimes came to power as Republicans faltered in the

${ }^{97}$ Williams, West Virginia: A History, 90. 
border and regions deeper in the South. ${ }^{98}$ Southern states saw that the "new governments neither won the acceptance of most white Southerners nor found the funding to turn impoverished states into prosperous ones." ${ }^{99}$ The border states also saw the defeat of Republican led governments. West Virginia's Republican demise followed that of Maryland's Union/Republican movement. In that state, Democrats relied on control of local political machines and hysterical pronouncements against black political participation. ${ }^{100}$ Missouri's Republicans lost power in 1872, shortly after West Virginia.

Remarkably, Republican rule in West Virginia ended prior to the removal of civil sanctions against former Confederates. This came despite confidence from the top of the ticket. Governor William E. Stevenson boldly stated that "there has never been a time when the spirit of improvement was so earnest or so extensive as at this moment.” He cited the expansion of free schools, the thousands of men building the Chesapeake and Ohio Railroad, and other accomplishments as proof that the Republican Party represented progress. ${ }^{101}$ Governor Stevenson's January 1870 plea to restore former rebels’ right to vote galvanized Democrats and divided the Radical from the Liberal Republicans in the months leading up to the election. Radicals generally supported harsh measures against ex-rebels. Liberal Republicanism started as a reconciliation movement, but later evolved into a party faction that opposed President Grant and patronage dispensing bosses. Possibly to make their own violent statement on the issue, Ku Klux Klan terrorists

\footnotetext{
98 "Bourbon" refers to the return of the old leadership, as in the restoration of the Bourbons to royal rule in France after Napoleon. In most cases this was a misnomer because the old ways had died. West Virginia Bourbonism was not too atypical in that it embraced a Jeffersonian caretaker state model whose low taxes and light regulations spurred the quick development of extractive industries.

${ }^{99}$ Summers, The Gilded Age: or the Hazard of New Functions , 31. Physical restoration of Southern infrastructure and prosperity in such a short time probably would have required a Marshall Plan type infusion of aid.

${ }^{100}$ Jean H. Baker, The Politics of Continuity: Maryland Political Parties From 1858-1870 (Baltimore: Johns Hopkins University Press, 1973), 177.

${ }^{101}$ Governor Stevenson to John Mason, May 5, 1870, Mason Papers.
} 
brazenly attacked a jail near Charleston, releasing prisoners and threatening jail officials. This incident coincided with outbreaks of Klan activity in Kentucky and former Confederate areas. ${ }^{102}$ Two months later, the Democratic State Convention nominated John J. Jacobs to run against Governor Stevenson and pledged to maintain the white race as "the superior and ruling race.” The convention emphatically voted down Johnson Camden's recommendation to endorse the proposed amendment proposed by W. H. H. Flick and its release of former Confederates from political prohibitions, revealing strains between the party leadership and its rank and file. ${ }^{103}$ In response, the Republican State Convention later produced a platform praising the Fifteenth Amendment as "essential to justice between men, the consistency of the Government, and to the harmonious relations between the races.” The platform also called for the removal of voting restrictions on former Confederates "who now frankly and honestly co-operate with us in restoring the peace of the country."104 When the final tally eventually appeared in December, Democratic winner John Jacobs beat Stevenson by around 2,000 votes and Republicans lost both houses of the Legislature even without the participation of former Confederates.

The party that smashed the West Virginia Republican Party into near-annihilation in 1870 had its own troubled factions. West Virginia historians categorize the factions as Regulars (faithful to party leadership in all cases), Redeemers (desiring to restore 1859 conditions as much as possible), Agrarians (obviously the farming interest) and the Kanawha Ring of lawyers with less ideology than ambition. Many party Regulars had supported the post Civil War dreams of economic development; some tried to work with

\footnotetext{
${ }^{102}$ New York Times, March 3, 1870.

${ }^{103}$ New York Times, June 10 and 13, 1870.

${ }^{104}$ Parkersburg State Journal, August 4, 1870. This was the West Virginia Republican Platform for this year.
} 
the Union Party years before, but drifted back to the Democrats due to the treatment of former Confederates and Republican stances on race. ${ }^{105}$ Powerful Democrats, such as Henry Gassaway Davis and Johnson Camden, shared dreams of prosperity based on industrial development. ${ }^{106}$ By the late 1860s, the restrictions imposed upon Confederates and the 1863 Constitution unified their efforts. Meanwhile, the Republican Party’s defense of disabilities and their ability to keep the old constitution collapsed.

This process started in the spring of 1871 with passage of the Flick Amendment. A year before, Republican Governor William E. Stevenson urged the Legislature to remove all civil sanctions against former rebels. Test oaths for certain professions disappeared within a month. W. H. H. Flick and others backed legislation to expand male suffrage rights to include blacks and former Confederates. In the Constitution of 1863, amended in 1865, Article III specified that white males "shall be entitled to vote at all elections.” This excluded paupers, minors, men of “unsound mind,” felons, or those convicted of treason or bribery of elections. It also distinctly excluded anyone who gave assistance to the Confederacy from the vote and citizenship in the state itself unless they subsequently enlisted into and were honorably discharged from the armed forces of the United States. ${ }^{107}$ Flick’s proposed Amendment sought to bring West Virginia law in line with the Fifteenth Amendment by striking out the provision on color while also advancing Governor Stevenson’s desire to bring former Confederates into full citizenship.

\footnotetext{
105 Gordon McKinney, Southern Mountain Republicans, 1865-1900 (Chapel Hill: University of North Carolina Press, 1978), 41-42. The passage of the $15^{\text {th }}$ Amendment, according to McKinney, strongly alienated Union Democrats from West Virginia Republicans.

${ }^{106}$ Williams, West Virginia and the Captains of Industry, 4-5.

${ }^{107}$ West Virginia Constitution of 1863, West Virginia Division of Culture and History, Charleston, West Virginia, http://www.wvculture.org/history/statehood/constitution.html.
} 
Voters passed the Flick Amendment in April of 1871, with national and state Republican publications in full support and the New York Times calling the question an "abstract principle.”108 As predicted, the amendment passed with an extraordinarily light turnout. The Wheeling Intelligencer lamented that the lack of participation was "a not very healthy indication" because it showed that voters showed no interest in elections that involved neither money nor personal interest. The editor may have spoken more accurately when he described how the amendment antagonized both parties. It required Democrats to positively affirm the verdict of the Fifteenth Amendment's passage while expecting the GOP to approve of adding former Confederates to the voting rolls. ${ }^{109}$ Light turnout combined with the passage of the law indicates resignation in the face of the events rather than enthusiastic acceptance of change.

Within four months the state put to the voters another major issue, that of forming a constitutional convention. Once former Confederates got the vote, Democrats stormed back into office and vowed to undo the system crafted by the statemakers. The scale of deconstruction divided them. Most agreed on creating a new Constitution, some stating that the plan of government was created by men of narrow minds. ${ }^{110}$ However they strongly differed on what their new West Virginia ought to look like. They hated the northern style township system and feared innovations such as voter registration. Republicans accused them of also opposing good roads and free schools, "if hostility to slavery, the advocacy of a free and general education, the repudiation of the dogmas of Old Virginia, and a hearty and sincere loyalty to the United States” were narrow sorts of

\footnotetext{
${ }^{108}$ New York Times, April 24, 1871. The article mentioned the support of the Wheeling Intelligencer.

${ }^{109}$ Wheeling Intelligencer, April 28, 1871.

${ }^{110}$ Referred to in Wheeling Intelligencer, January 9, 1872.
} 
views, the Wheeling Intelligencer was glad to claim them on behalf of the Republican Party. ${ }^{111}$

Firebrand former Confederates within the constitutional convention wished to reverse almost all of the innovations in the 1863 constitution. The most aggressive fought to symbolize their victory by renaming Grant and Lincoln counties after Davis and Lee. Eventually a more discrete proposition to change the county named after the eighteenth president to that of the first was even voted down. "Secession” Democrats also demanded that "white" be placed in the new Constitution so as to inform the world which race controlled the government of West Virginia. Convention president Samuel Price scored a victory for social coercion of voting by striking down the secret ballot (even a voluntary one!) as leading to "fraud and dissimulation."112 Union Democrats and moderates, despite their initial inability to grasp positions of power, checked most of the more extreme moves by the "bitter ender" element that tried to erase most of what the statemakers created and the Republicans perpetuated. The Wheeling Intelligencer issued a faint gasp of praise for their political opponents by February 19, asserting that "the Democracy have been making progress in spite of themselves now.” It went on to say that the Democratic dominated convention finally started to look for "broader ground. They find it occupied by Republicans." ${ }^{\circledR 13}$ Republican proposals that received the same treatment included a plan for proportionate representation that might have benefited them in the short term more than the long run.

At the end of the day, many West Virginians remained suspicious of the document hastily produced by the convention, and it passed with a less than impressive

\footnotetext{
${ }^{111}$ Ibid.

${ }^{112}$ Wheeling Intelligencer, February 19, 1872.

${ }^{113}$ Ibid.
} 
margin. Congressman John J. Davis, father of the 1924 Democratic nominee for the presidency John W. Davis, reported to Jonathan Bennett that "I do not wonder at the dissatisfaction with the convention on the part of the people. It failed to meet public expectations in its work and I fear it has done no good.” He went on to describe himself as "not impressed with its great superiority over the old one."114 Others feared the potential of a Democratic government and a constitution created by the same. The Preston County Journal warned of attempts by the Legislature to gerrymander districts to reduce Republican voting strength. ${ }^{115}$ Democrats divided over increasing government intervention and also the scale of industrial development. Western leaders long awaited the industrial development that had awakened economies in neighboring states even before the Civil War. J. H. Diss Debar, a promoter of West Virginia industrialism, developed a state seal that reflected the agricultural past, but also a confident future in mining and industry.

The Civil War continued to cast a dark shadow over the Democratic Party and its supporters. Union Democrats found themselves left out of leadership positions in both the Constitutional Convention of 1872 and the State Legislature. A Parkersburg newspaper complained that out of twenty-five officers, not one comes "from north of the Parkersburg Branch of the Baltimore and Ohio Railroad.”116 One can see the near disintegration of the state Republican Party in the hope that "the Republicans are quietly looking on and, may, through the division of their opponents, seize some little

\footnotetext{
${ }^{114}$ Representative John J. Davis to Jonathan Bennett, April 30, 1872, Jonathan Bennett Papers, West Virginia and Regional History Collection, West Virginia University, Morgantown West Virginia, Hereafter referred to as Bennett Papers.

115 Preston County Journal, 28 March 1872.

${ }^{116}$ Parkersburg Journal, quoted in Wheeling Intelligencer, 29 January 1872.
} 
advantages.”117 Going into 1872, Republicans were split over the "let up” movement and had their development ideals co-opted by the Camden and Davis faction of the Democratic Party. They could not muster even a feeble challenge to the dominance of a party strongly divided against itself.

Besides the constitution of the state, another major issue consuming the attention of state leaders lay in the physical location of government. The location of the state capital as well as several county seats sparked debate and even violence in this era. West Virginia’s “capitol on wheels” consumed tremendous political energy and real resources every time it switched between Charleston and Wheeling. For obvious reasons, the statemakers originally established the seat of state government in the northern panhandle city of Wheeling. Farther south, Union and Confederate forces struggled to seize control of the Kanawha Valley and its important salt resources for the first half of the war. One Confederate raid came as far north as Morgantown. No other city promised safety to a government that could have faced trial as traitors against the Commonwealth.

Charleston developed into an industrial town with the advent of the salt industry in the early 1800s. Mills to the east of the new and growing city churned out salt that eventually dominated trade in the Midwest until the 1850s. The city in the decades after the Civil War attracted speculators and promoters. ${ }^{118}$ Some of its original families came from the Greenbrier region, strongly connected to old Virginia. Others, such as the prodigious Young family, started their existence in America by settling west of Philadelphia, eventually making their way into Maryland and then to the Kanawha Valley. This mixture of people from different cultures and place helped to create a

\footnotetext{
${ }^{117}$ Wheeling Intelligencer, 29 January 1872.

${ }^{118}$ Ron Eller, Miners, Millhands, and Mountaineers: Industrialization of the Appalachian South, 18801930 (Knoxville: University of Tennessee Press, 1982), 58.
} 
border region mentality. So did the trade patterns extending east along the James River and Kanawha Turnpike into Virginia as well as those extending northwest up the Kanawha into Ohio and the Great Lakes region. Charleston first established itself in the gray borderlands that separated an unsteady America from the world of the Shawnee Nation and its angry allies. Interestingly, the city itself took on a genteel aspect, especially after becoming the seat of state government while historically the industry thrived in independent towns on the urban periphery. These aspects of blending and near contradiction highlight the border existence of Charleston and many other parts of West Virginia. Of course a border existence meant that it experienced a full measure of violence during the Indian and Civil Wars.

By 1869 Democrats and moderate Republicans, including the "let up" faction, sought to ameliorate scarred feelings in the Kanawha Valley over a perceived lack of attention to internal improvements in the southern part of the state. Gooden asserted that economic development at least partially motivated moderate Republicans. ${ }^{119}$ Charleston was officially designated as the capital in 1870; records and other materials soon arrived in April of that year by steamboat. According to Charles Ambler, "this removal gave many Charlestonians their first real interest in their new state." ${ }^{120}$ Establishment of the new capital coincided with the construction of the Chesapeake and Ohio Railroad that loosely paralleled the old James River and Kanawha Turnpike from the southeastern part of the state through Charleston and Guyandotte into Ashland, Kentucky. Developer Collis P. Huntington was able to get incorporated in 1871 a new city on the Ohio River bearing his name to dominate the trade that eventually flourished there. Charleston's new

\footnotetext{
${ }^{119}$ Gooden, “Completion of a Revolution,” 203-204.

${ }^{120}$ Charles Ambler, West Virginia: The Mountain State, 442.
} 
role as the seat of state government symbolized the shift from Wheeling Republican goals and aspirations to a new recognition of the southern and Democratic powers. ${ }^{121}$

The Constitutional Convention's location in Charleston seemed to serve as a signal of that city's permanent status as capital, but in 1875 the Legislature voted to remove the capital to its former home in Wheeling. Promises of newer and better facilities swayed opinions. Charleston businessman John P. Hale constructed a four story hotel in his home city to serve as an elegant home away from home (except for the inclusion of only one bathroom.) To top Charleston, Wheeling wooed the Legislature with an \$80,000 statehouse. Charleston Republican George W. Atkinson growled "Under no circumstances and for no consideration will they [people in the Kanawha Valley region] vote for any man for any office who votes to take the seat of Government from Charleston.”122 By the next session, the would-be state capital received a thanks, but no thanks resolution by the Legislature and started a process to move the capital again. In 1877 the Legislature finally placed the issue before the people. Charleston won the balloting over B\&O centers Clarksburg and Martinsburg. By 1885 the capital returned to its present and permanent seat. Indecision over the site of the capital paralleled uncertain notions about the direction of the state and its government. The battle over the capital in the 1870s and 80s was part of the context of the political battles of the period.

The year 1872 forever changed the state. Its new constitution created a government to satisfy Jeffersonians of the past, and, allegedly, lasseiz-faire style

\footnotetext{
${ }^{121}$ Ken Fones-Wolf, “A House Re-Divided”, unpublished.

122 George W. Atkinson to John W. Mason, December 8, 1875, Mason Papers.
} 
capitalists of the future. ${ }^{123}$ Limited government suited the Bourbons in West Virginia and elsewhere who feared the heavy hand of authority. The governor enjoyed a single term with no chance of re-election. Some patronage did exist, but not always enough to build power within his state party. Power within the Executive Branch was divided between the governor and his elected Cabinet, the combined assemblage known as the Board of Public Work, which included the auditor, treasurer, attorney general, and superintendent of free schools. The office of secretary of state at this point was an appointed position. Eventually, it would be chosen by voters and serve as an unofficial springboard for those with aspirations to the Governor's Mansion. The authors of the Constitution tried to include safeguards to prevent the combining of state power with that of railroads by declaring them to be public highways and banning their officials from election to the State Legislature. This reflected a potentially more powerful than recognized anticorporate element in West Virginia during the 1870s. ${ }^{124}$

Later governors, especially after the Republican takeover in 1896, expanded the authority of the position as much as they constitutionally dared. New fields of endeavor for the state, including expanded school and mental health facilities, provided more patronage opportunities as well as ways to build voter confidence in state services. That lay in the future. A procession of Democratic governors would own the office until 1896, often helping to advance the industrial development desired by Republicans while also frustrating that party’s political ambitions.

\footnotetext{
${ }^{123}$ Many have blamed lasseiz-faire style capitalism for the excesses of industrialism in West Virginia. West Virginia, even with its limited scope of power, played a dominant role in manipulating the economy in favor of some private interests at the expense of others. This is not the modus operandi of a hands off, caretaker state in the Adam Smith tradition. Smith is the thinker that most associate with the ideal of lasseiz-faire capitalism. He asserted that government interference in the economy produced unintended and negative results for many while only benefiting a few. Adam Smith, Wealth of Nations (New York: Bantam Classic, 2003), 667-669.

${ }^{124}$ Lewis, Transforming the Appalachian Countryside, 60-61.
} 
Another major change lay in the elimination of the despised township system, or rather the superimposition of county government over top of the 1863 townships. Renamed “districts," they functioned for many decades, especially in larger counties for many years as convenient subdivisions. Preston County is one of the few left in which citizens still make reference to their districts of residence. Power returned to the county court system which featured three commissioners granted financial, administrative, and judicial authority. This reflected the practice of old Virginia and would remain in place for almost a century.

The Constitution of 1872's ratification did not come easily. Even with the new heavily Democratic majority, the margin of passage did not reflect confidence int heir work. Republicans, of course, despised the changes. Governor Stevenson warned in a letter to the State Journal, "As an index to the reckless fanaticism which controls the majority of the current Legislature, it is only necessary to know the character of the laws they are enacting." ${ }^{125}$ It did accomplish a significant goal of the Democratic Party, but acknowledged at least the perpetual independence of the state and a permanent break from Virginia. Agrarians and Redeemers worked to build a system centered around Jeffersonian yeoman farmers and white male government. They undercut the basis of executive branch power, but in the long run failed to preserve their cherished principles of natural rights based law. The statemakers and subsequent Republican administrations did not see all their work undone.

Ready acceptance of the Camden and Davis supporting “regular” Democrats to seize the helm of the Unionist economic vision rendered irrelevant the first generation of

${ }^{125}$ Reprinted in Preston County Journal, February 15, 1872. 
the Republican Party. ${ }^{126}$ Without the economic issue, they had little beyond patronage with which to mobilize the party or its voters. The Chesapeake and Ohio trunk line as well as a multitude of branches and connectors spider webbed across West Virginia with the blessing of Democratic industrialists who built much of it themselves. At first, this facilitated logging and later the mining of coal. Republicans had to settle for a "me too" stance on state economic growth while struggling to use the protective tariff to differentiate themselves from their rivals.

Although Republicans lost their constitution and their grip on power by 1872, they could still look at the first years of statehood with a sense of accomplishment. The party itself still existed, which was better than the North Carolina Republicans could say after they vanished in the 1870 s. Democrats did come to power and return state law to a more Old Dominionlike condition, but did not undo the free school system. Their "Regulars" also tended to support industrial development. Finally, the state itself continued to exist. Democrats returning to power decided that they preferred the idea of running their own state to a return to Richmond-based rule. This provided little comfort to Republicans who found themselves in opposition for the first time since before the war, but it did mean that some aspects of their achievement would remain intact.

${ }^{126}$ John Alexander Williams, Appalachia , 182. 


\section{CHAPTER THREE}

\section{NATHAN GOFF AND THE PERILS OF PARTY RULE}

1872 looked dismal for the Republican Party nationally. It controlled Congress and the White House, but stared into the abyss of schism. The brief dalliance of the Democracy with the quasi-abandonment of racial politics ended with Horace Greeley’s campaign, and so the bickering Regular and Liberal Republican factions sullenly reunited. "Parties,” a Republican editor wrote, “live and die as they are devoted to measures.” Although he wrote this in a spring 1872 defense of Grant, the message remains important. It also indicates the division between the Liberals and Regulars. Political parties must accomplish goals in the real world to remain relevant. The Preston County-based writer noted that the Whigs had failed to meet this standard. ${ }^{1}$ Those accomplishments needed to benefit both people and party. Regardless of the rightness or wrongness of the moderate West Virginia Republican moves to allow former Confederates back into politics, they did go a long way towards healing the people, but they did little for the party. Republicans expressed frustration over the passage of the constitution and their own impotence to form any obstacle to Democratic Party designs. West Virginia’s Republican Party experienced almost complete collapse in the 1870s. Republican Senator Peter Van Winkle placed principle above politics when he opposed the removal of President Johnson. Internal dissention between hard line Radicals and "let ups” ended with the rush of former Confederates back into full citizenship. The remaining collection of former Whigs and statemakers quickly faded

\footnotetext{
${ }^{1}$ Preston County Journal, April 4, 1872.
} 
into almost irrelevance, except in certain pockets of strength. Some remembered the passing of certain statemaker luminaries from power as a disaster for West Virginia Republicans and other original state supporters who "ungratefully turned their back on their greatest.” Historian and journalist Granville Davisson Hall specifically referred to Unionist Democrat Daniel Lamb and his quest for the U. S. Senate, saying he was "the profoundest student of government problems since Madison.”2 Certainly Hall exaggerated somewhat, but the strong possibility exists that he meant to compare his favorite to Nathan Goff, who had assumed party leadership.

West Virginia Republicans’ low point came in the gubernatorial election of 1872 when they chose simply to endorse a Democratic candidate rather than field their own, mimicking the Democratic Party's strategy on the presidential level. With electoral victory and implementation of the "Bourbon" constitution, state Republicans looked to be drifting towards the fate of other Southern party organizations in the 1870s. Many in Southern states, such as North Carolina, found their bases terrorized by violence and immobilized by apathy. The North Carolina Republican Party eventually dissolved itself. $^{3}$ Although West Virginia voted for the first Union officer to hold the presidency, Ulysses S. Grant, once again in 1872, they did not vote for another Republican chief executive until the final Civil War veteran was elected president in 1896.

Grant’s presidency defined the 1870s. Debates over corruption and his ability to function as chief executive divided Republicans even at the state level. He consciously built his fortune on the boss system already in place. Trusting in self-interest trumped

\footnotetext{
${ }^{2}$ Granville Davisson Hall “The West Virginia Campaign of 1904,” Granville Davisson Hall Papers, West Virginia and Regional History Collection, West Virginia University, Morgantown West Virginia.

${ }^{3}$ Gordon McKinney, Zebulon Vance: North Carolina's Civil War Governor and Gilded Age Political Leader (Chapel Hill: University of North Carolina Press, 2004), 340-341. North Carolina Republicans announced their dissolution in 1878.
} 
idealism to Grant. His administration's mentality reflected a desire for loyal and effective commanders. On one hand, a Republican magazine that drifted into strong opposition during his first term admitted that "General Grant appears to be one of the most popular presidents that we ever had." ${ }^{4}$ It based its disappointment with the "Hero of Appomattox" on the fact that Grant did not, or thought he could not govern without the help of "rings, lobbies, and back stair influences generally.” They disliked his appointments, his foreign policy, and the fact that his personality was "plain as an average private" and "silent as a model picket.",

Many define the significance of the Liberal Republican revolt in terms of its eventual defeat. Mark Wahlgren Summers asserted that "Greeley never had a chance of beating Grant” because national prosperity assured general contentment with the president. $^{6}$ Jean Edward Smith in his biography of Grant called the victory in 1872 the climax of that presidency because it crushed both the Democratic opposition and the Liberal Republican rebellion. ${ }^{7}$ David Jordan, biographer of Grant supporting "Stalwart” Roscoe Conkling, described the Liberal Republican efforts as impossible. Jordan emphasizes the bizarre alliance of the Democrat baiter Greeley with the party he once hated, all in the name of the ideal they shared with Liberal Republicans of anybody but Grant. $^{8}$ Some who were separated by a few decades saw the party revolt as a minor event. William Allen White, a journalist whose career lay a generation after Grant’s presidency, described the movement as a "slight crack" and a "minor rebellion" against

\footnotetext{
4 “The Political Campaign of 1872,” North American Review, (October 1872), 402.

${ }^{5}$ Ibid, 403, 404.

${ }^{6}$ Mark Wahlgren Summers, The Gilded Age or The Hazard of New Functions (Upper Saddle River, NJ: Prentice Hall, 1997), 26.

${ }^{7}$ Jean Edward Smith, Grant (New York: Simon and Schuster, 2001), 552.

${ }^{8}$ David Jordan, Roscoe Conkling: Voice In the Senate (Ithaca NY: Cornell University Press, 1971), 17879.
} 
the "reactionary corruption" of Grant's administration. ${ }^{9}$ That being said, the idea that this represented a minor rebellion in American political history did not occur to those fighting it out at the time. The Wheeling Intelligencer led an aggressive West Virginia Republican charge against Grant in spring of 1872 and campaigned just as hard for him by August. ${ }^{10}$

The 1870s saw the zenith of the power of political "bosses" and their "machines." Bosses such as Roscoe Conkling in New York, Matthew Quay in Pennsylvania, and even Goff offended the sensibilities of a large faction of the Republican Party. Bosses utilized influence to obtain jobs and other favors for hardworking party men. This provided the foundation of their power, but failed to inspire the more idealistic members of the Republican movement. The party's bipolar nature from the beginning included a lofty minded reform set and a pragmatic business oriented group. In between the two sprouted the savvy political operators able to work honestly (and sometimes dishonestly) within the loose rules and standards of the time. Both parties had such men who found prosperous niches to develop political power and sometimes wealth.

Bosses found staunch opposition from idealists within the Republican Party across the country. These formed a small, but very vocal faction, that nipped the heels of President Grant and state party authorities. "Liberal Republicans,” as George W. Julian artfully explained, "asked [for] the expulsion of political corruption and the restoration of the party to the purity which had signalized its early life."11 Conkling noted that "their vocation and ministry is to lament the sins of the people. Their stock in trade is rancid,

\footnotetext{
${ }^{9}$ William Allen White, Autobiography (New York: Macmillan, 1946), 274.

${ }^{10}$ Wheeling Intelligencer, 14 May 1872 and August 21, 1872.

${ }^{11}$ George W. Julian, “The Death-Struggle of the Republican Party,” North American Review, (March 1878), 270.
} 
contrary, self-righteousness.” He pointed out that “parties are not built up by deportment, or by ladies’ magazines.",12

At what point does any political party or its supporters act in a manner which one may describe as “pure?” The job of a party lies in creating support and explaining issues in such a way as to convince people to donate to the cause and vote for candidates. Julian's career as a writer and a congressman reflected a desire for a cleaner brand of politics based on ideas and ethical practice. He rejected the blatant appeals to selfinterest, such as patronage distribution. Historian Heather Cox Richardson illustrated further divisions, describing how liberal Republicans did not accept the idea that inequalities by themselves prevented an individual from achieving success. Regulars responded by claiming their intent, especially under President Grant, was to develop the country for everyone, including blacks and Indians. ${ }^{13}$ However, as Paul Leland Haworth argued, the crushing defeat of Grant's opposition both inside and outside his party resulted in the "pleasant belief that the question of dispensing the loaves and fishes of political patronage was settled forever and that it was wholly unnecessary to carry through measures of reform.”14 These policies likely were more overlooked than endorsed by a nation grateful for the prosperity of Grant’s first term.

Republican struggles nationally created temporary tensions within the West Virginia party in 1872, but did not create the same kinds of lasting animosities and dissentions as elsewhere. West Virginia Republicans in 1872 found themselves

\footnotetext{
${ }^{12}$ H. Wayne Morgan, Hayes to McKinley : National Party Politics, 1877-1896 (Syracuse: Syracuse University Press, 1969), 37.

${ }^{13}$ Heather Cox Richardson, West From Appomattox: Reconstruction of America After the Civil War (New Haven: Yale University Press, 2007), 125.

${ }^{14}$ Paul Leland Haworth, The Hayes-Tilden Disputed Election of 1876 (New York: Russell and Russell, 1966), 3.
} 
temporarily divided over the issue of renominating Grant. The national party never fully fused the two sides of its original personality. The self-proclaimed liberal, formerly Free Soil wing, could not tolerate Grant. His hard-edged policies in the South and lighter touch with the western Indians won him few friends outside of the groups that directly benefited from his actions. Within the state, a seemingly strong Grant majority struggled against a vocal set of powerful figures in media and politics. Party leader Nathan Goff had to contend with a serious debate over national party affairs just when he was trying to construct an organization from the rubble of the recent state Republican collapse. Even worse, party divisions undermined the sometimes less than steady source of patronage that Goff relied upon to help reward the faithful and build the party. Prominent Republicans, such as former Brigadier General Benjamin Kelley, assured other party leaders that "if the committee are permitted to appoint the delegates, that they will all be opposed to the renomination of Grant."15 By 1872 one could call into question whether or not this statement reflected the accurate state of the party or Kelley's fragile health since he still suffered from the after effects of a serious war wound.

The Wheeling Intelligencer emerged in the first half of 1872 as a resounding voice against the renomination of Grant. His party's main press organ lobbed shots towards Grant’s friends in March by proclaiming “to renominate (Grant) is to renominate all the barnacles that unfortunately have attached themselves to his administration and to his personal fortunes.”16 Generally, much of the Republican criticism of Grant confined itself to the President's friends and advisors. Grant himself remained the "Hero of Appomattox," still worthy of having a county named for him, despite the unease

\footnotetext{
${ }^{15}$ Benjamin F. Kelley to John W. Mason, July 9, 1872, Mason Papers.

${ }^{16}$ Wheeling Intelligencer, March 7, 1872.
} 
surrounding his presidency. By the end of April, the newspaper called upon "Liberal Republicans" in the city to meet. It discussed the sending of delegates to the Liberal Republican Convention in Cincinnati and whether the delegation would support Horace Greeley or Charles Francis Adams. Although it claimed a "large amount of Republican support in this city with the Wheeling movement," unsubstantiated partisan paper claims should often be taken with a grain of salt. Then again, 32.8\% of Wheeling's 1860 population came from the same country as outspoken Liberal Republican Senator from Missouri Carl Schurz. Pre-Civil War meetings of Germans at times echoed proclamations of the Revolution of 1848 of which Schurz was a veteran. ${ }^{17}$ This could indicate one of the reasons for more Liberal Republican support in the Wheeling area. West Virginia Republican Party “regulars” failed to appreciate the anti-Grant stance of the Intelligencer. In the broader context of the political year of 1872, they saw a national party ripping itself apart while the most hated element of the Democratic Party, former Confederates, tried to grab power within the state. They saw for themselves in the Constitutional Convention of 1872 what a "bitter ender" government could look like. Division gave opposition an opportunity. Republicans worked diligently along the political lines of the time to enlarge their numbers at different conventions. The Intelligencer complained "The machinery of the party throughout the country is so completely in the hands of the interests of Grant that his renomination has been a thing virtually accomplished for months." ${ }^{18}$ That statement reflected the lingering bitterness from the Grafton Convention two weeks before to nominate delegates to the Republican National Convention. At that gathering, former Virginia Governor Francis Pierpont had

\footnotetext{
${ }^{17}$ Ken Fones-Wolf, “Caught Between Revolutions: Wheeling Germans in the Civil War Era,” in Ken Fones-Wolf and Ronald Lewis, ed. Transnational West Virginia, 25.

${ }^{18}$ Wheeling Intelligencer, June 2, 1872.
} 
argued against sending a delegation with instructions to support Grant. He pleaded that "the Republican family, sir, has been rent asunder to a large extent" and proclaimed that "there is a powerful disaffection," and the crowd hissed and voiced its discontent with the liberals. Most West Virginia Republicans chose their affiliation due to their love for and loyalty to the Union. Grant still symbolized that sacred bond to many of the soldiers, home guards, and people who risked all by simply taking a stand. Meanwhile, the Wheeling newspaper admitted that the state Republican Party had no chance at winning state elections without divided opposition. From a weakened position, the Republicans had to tailor their candidate selection to the possible strengths and weaknesses of their opponents. It advised the Grafton delegates not to nominate a state ticket before the Democrats chose theirs. ${ }^{19}$

The Cincinnati Convention of Liberal Republicans, called by one historian "a weird conglomerate," gave liberals the option of voting for Horace Greeley. ${ }^{20}$ Eventually, Greeley won the nomination after what one historian called "three days of backroom maneuvering that would have made a Tammany Democrat envious." ${ }^{21}$ The splinter movement grew into a threat when Democrats strangely joined in his nomination. Republicans at the very least united behind a candidate, whether or not they completely approved of him. After Greeley's failure in the Republican Philadelphia Convention and success in Baltimore, many party faithful wearily trudged back to the Grant banner. Greeley's increasing slide towards the Democracy gradually unified most of the disaffected elements. By August the Intelligencer called Greeley’s campaign a

\footnotetext{
${ }^{19}$ Wheeling Intelligencer, May 23, 1872.

${ }^{20}$ Jordan, Roscoe Conkling: Voice in the Senate, 179.

${ }^{21}$ Smith, Grant, 548.
} 
"complete failure" and pointed out that blacks found his "guidance" to be "patronizing."22

Still, complete unity behind Grant proved elusive. As late as November $2^{\text {nd }}$, the editors pleaded with Republicans not to mirror "the reluctance of Governor Pierpont" because a Greeley presidency meant a Democratic Cabinet. Francis H. Pierpont grumbled in 1874 that then Senator Arthur I. Boreman had convinced him to eventually support Grant, but only to gain the goodwill of the administration. Pierpont argued that West Virginia never saw any benefit from supporting Grant. ${ }^{23}$ As it turned out independent Democrat Thomas Hendricks won forty two electoral votes, giving him thirty-nine more than Greeley.

West Virginia Republicans attempted a similar ploy to that of the Democrats with Greeley. Regular Democrats ran Johnson Camden as a regular "Greeleyite” candidate for governor. Incumbent John Jeremiah Jacob ran as an independent whose candidacy was seconded by state Republicans. Some saw Jacob’s strength as a sign of Republican ascendency. The Cincinnati Gazette hailed the apparent significance of the triumph of Jacobs’ victory which, it thought, produced fatal divisions in the West Virginia Democratic Party. Divisions did exist, but Democratic Party factionalism was still years away from producing results dangerous to their continued hold on power. Ambler believed differently in terms of any kind of Republican victory. Low turnout could have also indicated voter apathy. Ambler stated that the slim margins that Jacob and Grant earned in West Virginia came from those who felt utter disgust with their party's

${ }^{22}$ Wheeling Intelligencer, August 23, 1872.
${ }^{23}$ Francis H. Pierpont to John Mason, March 7, 1874, Mason Papers. 
nomination of Greeley. ${ }^{24}$ Historian John Alexander Williams suggested that the blame, or credit, for Jacob’s victory went to Charles James Faulkner, whom he identified as both the driving force behind the new Constitution and the defeat of Camden. ${ }^{25}$ Like the national election, this united unlikely interests. Few Republicans waved the bloody shirt and hated Confederates more voraciously than rank and file Mountain State Republicans. It must have galled them considerably to sit on the same side as the former Confederate diplomat.

The election of 1872 gave West Virginia Republicans few reasons to rejoice. Democrats swept the Board of Public Works and maintained control of the Legislature. Jacob’s gubernatorial administration between 1872 and 1876 reflected the dissentions that consumed the Democratic Party during the election, yet in those four years the GOP failed to gain traction. All they could accomplish was cooperation with Union Democrats like Henry Gassaway Davis in fighting a rearguard action against Redeemers or disliked Regulars. The party needed a leader, and it turned to Nathan Goff.

West Virginia’s charismatic political boss, Nathan Goff Jr., seized the reigns of party leadership in the early 1870s and commenced the long and laborious task of rebuilding the shattered organization. Like many of his generation, Goff's Civil War experience provided instant credibility. He grew up in a prominent Clarksburg Whig family that had played a role in attracting the Baltimore and Ohio Railroad to the state. They condemned Virginia's secession ordinance and saw their son, Nathan, enter the Union Army. Clarksburg's central location ensured Union control, so the Goff interests did not suffer tremendously during the war. Goff served as an officer, seeing action

\footnotetext{
${ }^{24}$ Charles Ambler, West Virginia, The Mountain State (New York: Prentice Hall, 1940), 440.

${ }^{25}$ John Alexander Williams, West Virginia and the Captains of Industry (Morgantown: West Virginia University Libraries, 1976), 8.
} 
under Generals Robert Milroy and John Fremont. Most of his active service consisted of either engaging conventional forces coming west from the Shenandoah Valley or counterinsurgency actions in the hills and valleys of eastern West Virginia.

During the winter of 1864, Major Goff was captured along with thirty nine other members of the Fourth West Virginia Volunteer Calvary. Like most officer prisoners, the Confederacy sent Goff to Libby Prison in Richmond. At first the conditions ranged from acceptable to very unpleasant. ${ }^{26}$ His experience there only enhanced his postwar reputation and gave him the right credentials to lead the "bloody shirt" generation of Republicans.

The historiography of the post-Civil War industrial period has less to say about Goff than some of his contemporaries. Perhaps his story paled in comparison to those of the statemakers or the industrialists. Goff's sometimes nearly illegible handwriting and reluctance to share emotions and details in correspondence make him somewhat less accessible than some others. He led the state party during a time of extreme collapse, carefully resetting the foundation upon which future Republican leader Stephen Elkins would eventually triumph. However, Goff bestrode the narrow Republican world as a Colossus in some ways. He did not make other men seem petty, but few conversations about the West Virginia Republican Party before 1900 failed to include him. The Wheeling Intelligencer in 1884 called him "the Plumed Knight of the Little Mountain State,” an obvious comparison to the charismatic senator and occasional presidential candidate James G. Blaine of Maine. ${ }^{27}$ Goff bridged the gap between the statemakers and

\footnotetext{
${ }^{26}$ G. Wayne Smith, “Nathan Goff Jr., In the Civil War” West Virginia History 14 (January 1953): 108-135.

${ }^{27}$ Gerald Wayne Smith, Nathan Goff: A Biography (Charleston: Educational Foundation, 1959), 134.
} 
the industrialist, served as the undeniable leader of the state party, and built a national reputation.

Goff entered public life soon after the Civil War, building a future constituency by working with veterans. He chaired the Committee on Organizations of the Soldiers' and Sailors' State League starting in February of 1866. ${ }^{28}$ By 1867, Goff won election to the West Virginia House of Delegates, then received appointment as United States Attorney for West Virginia in 1868. As U. S. Attorney, Goff spent a great deal of time dealing with the state registration laws and violators of whiskey revenue acts. The future party leader raised eyebrows by unseating an incumbent Republican Representative, former brigadier general Isaac Duval, in the nominating convention of 1870, only to lose to a Democrat. Goff's rapid rise and brash action alienated the statemaker generation of Republicans, an attitude reflected by the post-election condemnation of "personal ambition” by the Parkersburg State Journal. ${ }^{29}$

Goff's political style lay in creating the image of the reluctant statesman dragged away from his business commitments by the glaring needs of people and party. ${ }^{30}$ In reality Goff's ambitions focused strongly on the most prominent political plum, the United States Senate. However, he needed a Republican legislature to accomplish that goal. Goff had political resources in the 1870s not available to modern political authorities. While the West Virginia Republican Party in the late twentieth century and early twenty first struggled to build beyond their core of traditional and ideological

\footnotetext{
${ }^{28}$ Petition sent to Governor Stevenson, August 11, 1870 and Mrs M. E. Ptomey to Nathan Goff, February 15, 1870, Nathan Goff Jr. Papers, West Virginia Regional and History Collection West Virginia University, Morgantown West Virginia. Hereafter referred to as "Goff Papers."

${ }^{29}$ Parkersburg State Journal, 3 November 1870.

${ }^{30}$ Gordon McKinney, Southern Mountain Republicans: 1865-1900 (Chapel Hill: University of North Carolina Press, 1978), 151.
} 
Republicans, Goff offered the "plums” of office to respected and hard-working figures. Early in the 1870s, Goff did have power, but not an iron grip on dispensing patronage. Arthur I. Boreman held a United States Senate seat from 1869 until 1875. From there he tried to influence decisions on federal jobs, as when he implored President Grant not to allow Benjamin Kelley to interfere with the appointment of Isaac Duval as collector in the West Virginia First District. ${ }^{31}$ Some reason exists to speculate that relations may have been strained between the first governor and the newcomer in the 1870s. Boreman, for example, backed Isaac Duval's candidacy for the collectorship in 1873. This was only a few years after Goff unseated incumbent Duval for the Republican congressional nomination, then promptly lost the general election. If strained relations existed, they probably did not last. Goff tended to support Duval later.

Goff may have actually benefited from Democratic control of the state legislature because it eliminated Boreman as a potentially competing center of power when it voted in one of their own upon the expiration of the former governor's term. Even as late as 1876, Goff did not seem to have the full backing of Grant as he was unable to protect Hedgeman Slack’s position as United States Marshal. If acrimony existed between Boreman and Goff, it did not emerge in this issue because those two plus Isaac Duval enthusiastically supported Slack. None of the West Virginia Republican power figures prevailed. Instead the job went to George Patton, a friend of Simon Cameron. ${ }^{32}$ This

\footnotetext{
${ }^{31}$ Senator Arthur I. Boreman to President Ulysses S. Grant, March 20, 1873, Department of the Treasury Records, Record Group 56, National Archives, Archives II, College Park, MD. Hereafter referred to as Department of the Treasury Records, Record Group 56.

${ }^{32}$ Nathan Goff to President Grant, May 27, 1865 and Theodore Wright to James Wright, December 28, 1880, Department of Justice Records, Record Group 60, Archives II, National Archives, College Park, MD. Hereafter referred to as Department of Justice Records, Record Group 60.
} 
demonstrates that Goff had substantial, but not complete control, over this vital means of constructing a political party.

Goff received appointment as a United States Attorney after his stint in the West Virginia House of Delegates. This represented the most prestigious in-state position of the patronage jobs open to West Virginia political figures. The state Republican Party recognized Goff's combination of name recognition and ability. As a result, it consistently pushed him towards progressively higher offices while he honed his political skills. When men such as Goff and George W. Atkinson rose in importance, they gently pushed aside the Republican state fathers with the power of patronage. ${ }^{33}$ The newer generation of Republicans tended to support business and industrial development more than the older agrarian oriented leaders. Friendly media outlets also helped to construct popular images of candidates and leaders as well as tear apart the opposition. When running for the House of Representatives in 1870, one newspaper supportive of his ambitions referred to Goff as "a fine scholar, well informed on current political topics." The paper insisted Goff "will reflect credit upon our State in the halls of our National Congress. ${ }^{34}$

Interestingly enough, many of these jobs handed out as rewards do not show on the surface the direct involvement of Goff. The recommendation packets that accompanied most applications for patronage positions include many from politicians out of office in the 1870s, such as Willey. Goff only rarely wrote in favor of an applicant,

\footnotetext{
${ }^{33}$ John Alexander Williams, "Davis and Elkins of West Virginia; Businessmen in Politics” (Ph.D. diss., Yale University, 1969), 65. Goff's elevation coincided with the loss of power of Republican agrarians such as Waitman T. Willey. Also see Ronald Lewis, Transforming the Appalachian Countryside:Railroads, Deforestation and Social Change in West Virginia, 1880-1920 (Chapel Hill: University of North Carolina Press, 1998), 243.

${ }^{34}$ G. Wayne Smith, Nathan Goff Jr.: a Biography; With Some Account of Guy Despard Goff and Brazilla Carroll Reece (Charleston WV: Education Foundation, 1959), 82.
} 
and, even then he expressed himself even to the president in tones of unquestionable authority, as when he seemed to dictate several years later to President Chester Arthur, "I trust you will continue Gen. Duvall of the $1^{\text {st }}$ District and not Collector (former Loyal Virginia Governor) Pierpont of the $2^{\text {nd }},{ }^{35}$ In 1877, Secretary of War Alphonso Taft wrote a letter to Goff, referring to a "suggestion" that the latter made concerning the possibility of Clarksburg native, Colonel Henry Haymond, serving on the West Point Board of Visitors. The word suggestion seemed overly emphasized, as if Goff, as per usual, had tried to dictate his wishes. Goff seemed eager to get his man into the office with Grant's administration still in place, but received word that no new appointments would receive consideration until April. ${ }^{36}$ Goff supported Maine Republican Senator James G. Blaine over Hayes for the nomination in 1876, earning initially cool treatment from the president. ${ }^{37}$ His apparent apprehension about Hayes and his policies on federal employment seemed confirmed a few months later. Goff, as well as other appointees across the nation, received instructions from the president that "no officer should be required or permitted to take part in the management of political organizations, causes, conventions, or election campaigns. ${ }^{\text {38 }}$ This might account for the dearth of political correspondence for long periods in Goff's papers.

Goff's goal lay in fusing the original Union Republicans with those more concerned with establishing industrialism in the state. ${ }^{39}$ He used his name recognition and the fact that he had never advocated Confederate persecution as a way to try and

\footnotetext{
${ }^{35}$ Nathan Goff to Chester Arthur, June 22, 1883, Department of the Treasury Records, Record Group 56.

${ }^{36}$ Secretary of War Alphonso Taft to Nathan Goff, February 17, 1877, Goff Papers.

${ }^{37}$ Smith, Goff, 106.

${ }^{38}$ President Rutherford B. Hayes to Nathan Goff (form letter to all civil service employees) June 22, 1877, Goff Papers.

${ }^{39}$ Ibid., 151.
} 
build support for a weak minority party. His leadership position over a party with few other big names meant that Goff occasionally found himself in "hopeless, but necessary" campaigns. ${ }^{40}$ Goff traveled extensively and spoke often. These efforts were supplemented by a rather disorganized party where the work of a few carried most of the burden. ${ }^{41}$ Local Republican leaders saw Goff as a foil for charismatic Democratic presenters. ${ }^{42}$ Between 1870 and 1876, West Virginia Republicans did not even hold a state convention. In the bicentennial year, Goff employed one of his favorite methods of gaining nomination, stating emphatically that he did not care to run while subordinates lined up the necessary votes in convention. Historian John Alexander Williams described the tremendous odds he faced; "entrenched in the interior counties and in tradition minded districts along the Virginia border was a pre-industrial political system.” Campaigning in this environment placed high value on oratory, face to face contact, and capable proxies carrying the party message. Travel, especially in the 1870 s, to remote mountain districts required time and stamina. ${ }^{43}$ Nathan Goff had just the right characteristics to succeed in such an environment given time, but state Republicans needed about ten of him.

Goff's influence came from a variety of sources, of which patronage represented one of the most important. Financial support or hard work on behalf of the party earned one a path into "the kingdom” as one Republican Party Executive Committee Chair and state governor, William Mercer Owens Dawson, described it. ${ }^{44}$ Goff benefited from a

\footnotetext{
${ }^{40}$ Gerald Wayne Smith, “Nathan Goff Jr.: A Biography” (PhD Dissertation, West Virginia University, Morgantown WV, 1954), 98, 99.

${ }^{41}$ Ibid, 93.

${ }^{42}$ G. F. Taylor to Nathan Goff, August 2, 1876, Goff Papers.

${ }^{43}$ John Alexander Williams, West Virginia and the Captains of Industry (Morgantown: West Virginia University Library, 1976), 11.

${ }^{44}$ W. M. O. Dawson to Stephen B. Elkins, April 23, 1900, Elkins Papers.
} 
good relationship with Grant, but occasionally had to struggle against the patronage policy of Rutherford B. Hayes. Hayes’ campaigners waved the bloody shirt for the Civil War general, but the emphasis after victory was on practical reconciliation. ${ }^{45}$

Goff used patronage as effectively as he could. During the 1870s and most of the 1880s, no other state Republican held his level of authority over federal hiring of the party faithful. Other elements of his incremental approach helped to quietly reconstruct party strength. Goff understood the necessity of remembering the voters. He pushed appointees and elected officials to work hard for their constituency. Individuals wanted action on pension applications, access to the free products of the Department of Agriculture, business subsidies and access to railroad connections. By cultivating a reputation of attentiveness, the West Virginia Republican Party could start to reverse the avalanche of the early 1870s and move towards legitimate electoral challenges again. ${ }^{46}$ Goff also shied away from controversial national issues, an attitude shared by others in the party. ${ }^{47}$ The 1870s divided the Republican Party nationally, and Goff wanted to limit the damage to his own organization.

Questions of patronage sometimes extended beyond a simple request for political reward. In 1876, former Brigadier General Benjamin Kelley sent an appeal to Goff for a federal position. Kelley's job for much of the war had been to keep in operation the mountain traversing section of the Baltimore and Ohio Railroad. His command also sent out patrols to search for guerilla forces in the area. Kelley, along with General George Crook, was captured by Confederate partisan rangers from a seemingly secure hotel in

\footnotetext{
${ }^{45}$ Ari Hoogenboom, Rutherford B. Hayes: Warrior and President (Lawrence: University Press of Kansas, 1995), 308.

${ }^{46}$ Gordon McKinney, Southern Mountain Republicans, 1865-1900 (Chapel Hill: University of North Carolina Press, 1978), 75.

${ }^{47}$ Francis H. Pierpont to John Mason, March 7, 1874, Mason Papers.
} 
Cumberland, Maryland. After the war he immersed himself in Republican politics and eventually secured a position as Collector of Internal Revenue. Many sent pleas on Kelley’s behalf throughout the early 1870s. Rutherford B. Hayes and Archibald Campbell cited his advanced age and disability from war wounds as a reason to give him an office. ${ }^{48}$

Senator Boreman had previously gotten Kelley removed from office. Boreman complained to President Grant in March of 1873 that Kelley interfered with the appointment of General Isaac Duval for a collectorship position. ${ }^{49}$ Complaints followed Kelley’s removal. Moderate Democrat John J. Davis called the firing "an act of injustice to Genl. Kelley.” He further explained that the former collector had won the respect of both political parties, and, most importantly, was "an unflinching and active supporter of the administration and I have never heard his fidelity to the Republican Party called into question. ${ }^{\text {50 }}$ Three years later, the formerly proud commander at Fort Fuller, now a broken old man, penned a sad letter to Goff. Kelley explained that he had tried to retire to his farm to support his wife and two grandchildren left to him by his son who was killed in the war. After paying taxes and other expenses, no money remained to support his family. Kelley begged for any open position, even with an Indian agency that would take his family far from their home. Toward the close of his letter he added as delicately as possible the fact of his personal acquaintance with Grant, despite his fierce opposition in 1872 to the president's renomination. ${ }^{51}$ Others in the past had recommended him due

\footnotetext{
${ }^{48}$ Hayes to Grant, December 14, 1870. A. W. Campbell to Grant, December 13, 1870, Record Group 56, Department of the Treasury Records.

${ }^{49}$ Arthur I. Boreman to President Grant, March 20, 1873, Record Group 56, Department of the Treasury Records.

${ }^{50}$ John J. Davis to J. W. Douglas, Commissioner for Internal Revenue, March 18, 1873, Record Group 56, Department of the Treasury Records.

${ }^{51}$ Brigadier General Benjamin F. Kelley to Nathan Goff Jr., December 12, 1876, Goff Papers.
} 
to his "patriotic service." ${ }^{\text {52 }}$ Eventually he did receive a position on an Indian reservation. Kelley's story shows the human side of Republican patronage. In the absence of sufficient pensions for soldiers, job openings could go to reward not only loyal Republicans, but also men who had sacrificed for their country during the war. One cannot imagine the pain of General Kelley, first from a permanent war injury, and, secondly, having to beg for a government job because he was physically unfit to support his family otherwise. Kelley was one of all too many former soldiers in that same situation. His story also reflects some of the different factors that entered into decisions about who received the limited number of jobs available for distribution.

Goff had powerful influence, but not a complete stranglehold on federal patronage. In 1871 he relied upon Hedgeman Slack, United States Marshal based in Charleston, to serve as his right hand. Slack faithfully reported, for example, the level of Kanawha County support for a constitutional convention. He also advised Goff on courthouse construction in Harrison County. Letters from Slack always ended with an informal "your friend, Slack." 53 Slack was appointed marshal on the recommendation that he was a "good sound unadulterated Radical Republican." 54 At the end of Grant's second term came a movement to remove Slack. Goff protested in the spring of 1876 that Slack was "a good soldier, is a true Republican, [and] has been a faithful and efficient officer." ${ }^{55}$ Others argued that Goff's friend had been negligent in terms of supporting the efforts of the party and that their candidate, George W. Patton, would

\footnotetext{
${ }^{52}$ J. M. Harris to President Grant, November 15, 1872, Record Group 56, Department of the Treasury Records.

${ }^{53}$ H. Slack to Nathan Goff, June 21, 1871 and H. Slack to Nathan Goff, August 25, 1871, Goff Papers.

${ }^{54}$ C. W. Smith to President Grant, May 2, 1869, Department of Justice Records, Record Group 60.

${ }^{55}$ Nathan Goff to Grant, May 27, 1876, Department of Justice Records, Record Group 60.
} 
exert himself more politically. ${ }^{56}$ Slack’s supporters included Arthur I. Boreman, who emphasized Slack's actual job performance. ${ }^{57}$ Patton eventually got the job, perhaps in part due to his personal connection with Simon Cameron. ${ }^{58}$ Despite a few occasional setbacks, Goff generally could tug on executive branch strings and obtain positions. About six weeks before leaving office, Secretary of the Treasury Benjamin Bristow informed Goff that he had found a position for Miss Alice Jeffries of Charleston and that she could start work on June $1,1876 .{ }^{59}$

Goff tried to expand Republican efforts into every part of the state. As one source described it, state Republicans “carried on in every county a sort of guerilla warfare,” supporting independent candidates, trying to undermine Democratic control while "in not more than a half a dozen counties in the State has a regular republican organization even existed.”60 Goff did rely on a network of friends throughout the state to keep him alerted on local developments. Charleston lawyer H. C. McWhorter kept Goff apprised of developments in the Kanawha Valley and the state government after the capital relocated there. McWhorter did not mince words to his friend on his town of residence and business, claiming it was "not fit to have the capital until its people become civilized, partially at least.”61 Hedgeman Slack’s service as Marshal did not prevent him from “electioneering for three days night and day” in $1871{ }^{62}$ Future Governor George Atkinson remained one of Goff's strongest supporters and political workers. The

\footnotetext{
${ }^{56}$ M. J. Bell (of Charleston) to Grant, January 4, 1876 and J. H. Huling to President Grant, January 13, 1876, Department of Justice Records, Record Group 60.

${ }^{57}$ Arthur I. Boreman to President Grant, May 26, 1876, Record Group 60, Department of Justice Records.

${ }^{58}$ Theodore Wright to James Wright, December 28, 1880, Record Group 60, Department of Justice Records.

${ }^{59}$ Secretary of the Treasury Benjamin Bristow to Nathan Goff, May 13, 1876, Goff Papers.

${ }^{60}$ New York Times, July 28, 1876.

${ }^{61}$ H. C. McWhorter to Nathan Goff, January 31, 1877, Goff Papers.

${ }^{62}$ Hedgeman Slack to Nathan Goff, June 21, 1871 and August 25, 1871, Goff Papers.
} 
Columbia Law School graduate won election to the Republican State Executive Committee in 1876 and was elected chair in 1880.

Goff's associations with Johnson Camden led some to accuse him of membership in the Democratic machine. Goff was no Democrat, but he did share with some Regulars in the Democratic organization the goal of industrializing West Virginia. Also he understood the reality of leading a party whose registrations had fallen far behind the opposition. Differences existed between Goff Republicans and Democrats, especially over the Constitution of 1872. Personal support from Goff's friends and appointees helped him forge the beginnings of a Republican Party that would take a long time to revitalize.

Undeterred by his 1870 setback, Goff ran again in 1874. Sitting out of the governor’s race in 1872 most likely cost the West Virginia Republicans prestige. Some Republicans in 1874 still argued for an alliance with Democratic supporters of Jacobs, considering an offer of support for him if he chose to run for U. S. Senate. ${ }^{63}$ Goff launched an aggressive campaign, banking on his oratorical skills and attacking "ring democracy.” ${ }^{\circ 4}$ Privately, Republicans saw an opening as Jacobs and Camden Democrats relentlessly pursued their political feud. ${ }^{65}$ Democratic nominee William L. Wilson seemed to run more against the controversial President Grant than the young and popular Civil War hero, Goff. Despite "lack of organization and effort,” Goff came close to

\footnotetext{
${ }^{63}$ Francis H. Pierpont to John W. Mason, March 7, 1874, Mason Papers.

${ }^{64}$ Gerald Wayne Smith, "Nathan Goff”, 91.

${ }^{65}$ D. D. S. Farnsworth to John W. Mason, March 10, 1874, Mason Papers.
} 
victory. ${ }^{66}$ The New York Times actually declared on October 15 that the returns slightly favored Goff, but in the end he lost by 168 votes. $^{67}$

Sometimes Goff's own ambitions ran counter to his need to maintain relations within the party. He loved to play the reluctant tribune, dragged into elections unwillingly by the love of the people. The gubernatorial election of 1876 put Goff at odds with the Berkeley County Republican Executive Committee when Goff pledged his support to their county’s “favorite son” Colonel Lamont, then accepted the nomination himself. ${ }^{68}$ He eventually lost to former Confederate officer Henry Matthews. Goff pledged to that county's Republican committee that he "would not accept the nomination under any circumstances." "69 Goff tried to reassure Evans that "no one regrets the nomination more than I do myself." He claimed that he had to relent in the face of the wishes of "leading Republicans from all parts of the state.”70 If Goff intended to deceive Evans, he played the role across the state, telling Judge E. Maxwell, and one George Brown that he had no desire to be governor and no time to campaign. ${ }^{71}$ Berkeley County aside, some Republicans expressed the belief that Goff enjoyed better support than the party itself. Atkinson assured Goff that the Kanawha Valley backed Goff more than the rest of the Republican ticket. ${ }^{72}$ Goff lost that election in a season that saw the Democrats surging dramatically, compared to their showing of four years earlier when they did not

\footnotetext{
${ }^{66}$ Gerald Wayne Smith, "Nathan Goff”, 90.

${ }^{67}$ New York Times, October 15, 1874.

${ }^{68}$ Nathan Goff to George Evans, Secretary of the Berkeley County Republican Executive Committee, August 7, 1876, Goff Papers. This result in the age of conventions was by no means unique. James A. Garfield entered 1880 as an organizer for the John Sherman drive to the presidency. The convention nominated Garfield instead of Sherman, former President Grant, and former candidate James Blaine.

${ }^{69}$ George Evans, Secretary of the Berkeley County Republican Executive Committee to Nathan Goff, August 2, 1876, Goff Papers.

${ }^{70}$ Nathan Goff to George Evans, August 7, 1876, Goff Papers.

${ }^{71}$ Nathan Goff to Judge E. Maxwell, July 26, 1876 and Nathan Goff to George Brown, July 27, 1876, Goff Papers.

${ }^{72}$ George Atkinson to Nathan Goff, August 14, 1876, Goff Papers.
} 
even nominate one of their own for president. Machine politics exasperated the country after the various scandals under Grant. Historian Heather Cox Richardson illustrates the problem facing Goff, Hayes, and almost any other Republican in the bicentennial year. She writes that the Republican Party "had little to offer voters other than the destruction of slavery and defense of 'government by the people, for the people, and of the people."»73 Republicans also suffered from the political fallout of the recession and a popular belief among many that the party handed governing power over to blacks and big business. $^{74}$

What did Goff and the Republican Party actually offer the voters in the 1870s? Richardson's arguments that the 1870s Republicans offered little of substance does not entirely hold true at the state level. Certainly West Virginia Republicans did remain proud of emancipation and victory in the Civil War, but they saw their party as more important than simply existing as a living monument to those issues and statehood. They fought, but for what did they fight? Some battled to ensure that gains made during the 1860s remained in place. W. M. O. Dawson, editor of the Republican Preston County Journal, advocated the continued improvement of schools, complaining in 1873 about low pay leading to a deficiency of qualified teachers. ${ }^{75}$ Other Republicans encouraged rail expansion, but also blasted the state government for poor roads. The Wheeling Intelligencer noted that bad conditions were "a great drawback, not only to the attraction, but also the profit of country life." ${ }^{\text {76 }}$ Republican rhetoric in general expressed fears about Democratic leaders working to slowly deconstruct the results of the Civil War. "The war

\footnotetext{
${ }^{73}$ Heather Cox Richardson, West From Appomattox: Reconstruction of America After the Civil War (New Haven: Yale University Press, 2007), 172.

${ }^{74}$ Ibid, 175.

${ }^{75}$ Preston County Journal, October 25, 1873.

${ }^{76}$ Reprinted in Preston County Journal, April 18, 1874.
} 
is over," proclaimed the Intelligencer in response to complaints about "bloody shirt" campaigning "and if its results were in good faith accepted, there would be no need for reviving or keeping alive its recollections." ${ }^{\text {77 }}$ In West Virginia, tangible evidence of that desire to diminish Republican achievements came in the form of the Constitution of 1872, a document blasted as expensive, vague, a source of conflict between branches of government, and a restoration of local self-rule that only worked to the benefit of "courthouse cliques." ${ }^{\text {78 }}$ Probably the best summation of the Republican position in that decade came in January of 1872 when the Intelligencer defended the party against accusations of contracted and narrow viewpoints. It admitted guilt "if hostility to slavery, the advocacy of a free and general education, the repudiation of the dogmas of Old Virginia ... and a hearty and sincere loyalty to the United States” could be defined in that fashion. ${ }^{79}$ By the 1880s this list of values included a strong defense of the protective tariff and even advocacy of women's suffrage. ${ }^{80}$

Republicans promoted these issues and mobilized voters in their defense. The 1870s also was an era of political personalities. Conkling, James "the Plumed Knight” Blaine, and other similar figures paraded across the national stage. They put a face on the party in a time when political oratory represented both art and entertainment. It could sink or save a movement because it represented most Americans' connection to the political process. Goff mastered the art of public presentation and pulled strings to obtain jobs to become a powerful leader of the state party by the mid-1870s. He utilized a charismatic style of public speaking to reach voters. At this time much of the electorate

\footnotetext{
${ }^{77}$ Wheeling Intelligencer, May 28,1876.

78 Ibid.

${ }^{79}$ Wheeling Intelligencer, January 9, 1872.

${ }^{80}$ Ibid, January 7, 1888.
} 
lived in isolated areas and had insufficient education to understand one of the many partisan newspapers flourishing in the late $19^{\text {th }}$ century. One editor suggested "public speaking is the only kind of campaign work that accomplishes anything.”81 Even when called upon for impromptu talks, Goff retained a large repertoire of prepared material in his mind that centered on basic themes such as the perpetuation of Republican power and the positive aspects of the protective tariff. ${ }^{82}$ Goff's political talents and leadership led William MacCorkle, Governor of West Virginia from 1892-96, to claim later that "for twenty-five years, he was the Republican Party in West Virginia.,

Goff's generation looked to continue creating a different West Virginia. Both Democrats and Republicans in his generation responded to the vision of industrial development. Newspapers and elected officials in the 1870s often looked to "boom" development, particularly in railroad construction. The Phillippi Republican gushed, "no event will ever deserve a prouder place in her history than ... the formal opening of the Grafton and Greenbriar Railroad.” ${ }^{84}$ Gaining access to modern transportation, whether an 1870s railroad or a twentieth century divided limited access highway, has often been seen las a sign of progress and a step towards prosperity. Sometimes that progress was defined not just as a step towards an industrial future, but a step away from the "old ruts of a dead and past civilization." ${ }^{, 85}$ This statement took a double shot at road travel and the Old Dominion. In both cases the arrival of infrastructure sometimes exceeded expectations and, in other instances, produced considerable disappointment. Also the

\footnotetext{
${ }^{81}$ Williams, West Virginia and the Captains of Industry, 11.

${ }^{82}$ Leonard McCutcheon Davis, “The Speeches of Nathan Goff Jr.” (Ph.D. diss., Northwestern University, 1958), 138.

${ }^{83}$ William MacCorkle, Recollections of Fifty Years (New York: G.P. Putnam’s Sons, 1928), 432.

${ }^{84}$ Phillippi Republican, January 31, 1884.

${ }^{85}$ Ibid.
} 
effect on the surrounding area in both instances produced volatile political reactions. Eventually the debate on industrialism fatally divided Democrats in West Virginia. Lewis points out that even the four major factions of the Democratic Party often spawned further factions at the local level, hindering cohesive operation. ${ }^{86}$ In the 1870 s, many leading Democratic Party figures supported development, especially with the 1873 arrival of a major trunk line (the Chesapeake and Ohio) right through their areas of strength in the southern part of the state.

Johnson Newlon Camden and Henry Gassaway Davis, industrialists themselves, maintained a precarious hold on party leadership. As time passed, their hold on Democratic affairs deteriorated. Part of the problem lay in the "large army of the discontented ... Irish voters (who) were perhaps the most clamorous.” They demanded their "fair share" of patronage handouts when Democrats controlled the presidency. Their anger boiled over in the senatorial election of 1886 when they advocated "anything to beat Camden.” Of course these immigrant industrial workers had to join hands with the agrarian faction to do so. ${ }^{87}$ Those days lay in the future, but the seed of revolt against the industrialist leadership started germinating in this decade. In the 1870s Democrats seemed better able to cobble their different factions into coherency while the Republicans struggled to unify themselves at home and around the nation.

One of the more divisive issues at the time was the rapid expansion of railroad networks after the 1870s. It helped divide Republicans along lines already drawn in the election of 1872. Regulars favored development, while the smaller Liberal faction tended to be in opposition. On the Democratic side, Agrarians organized opposition to

\footnotetext{
${ }^{86}$ Lewis, Transforming the Appalachian Countryside, 213.

${ }^{87}$ Festus P. Summers, Johnson Newlon Camden: A Study in Individualism (New York: G. P. Putnam's Sons, 1937), 295.
} 
Democratic Party factions that promoted development. Agrarians opposed taxation of farmers to subsidize rail construction. They also feared the effects of rail traffic on the nearby countryside. ${ }^{88}$ Agrarian political revolts against Democratic Regulars would help boost Republican chances in the 1880s. Railroad entrepreneurs tried to enter mercantilist style relationships with individual counties. According to Lewis, Jefferson County courted disaster by entering into a relationship with the Shenandoah Valley Railroad. County voters approved a quarter million dollar subscription with the promise of more jobs and business. This development failed to materialize when the railroad imported workers from outside and opened its own stores. Lower transportation costs never happened, except where circumstances allowed for real capitalistic competition with the S. V. R. Jefferson County received a large amount of worthless stock in the debt saturated company and, in return, gave substantial tax breaks to the railroad. In this case, the combination of government and capital once again undermined the free market economy and individual property rights while saddling the county with overwhelming financial burdens. ${ }^{89}$ According to John Alexander Williams, "It is difficult to think of anything in Appalachian life that the coming of the railroad did not change." ${ }^{.90}$ In this case, railroads helped to change politics, economics, and even the concept of justice by emphasizing the greater collective good over natural rights based law. These transformations formed a key part of the world that Goff and his party wished to lead and guide.

Appalachian political historian Gordon McKinney tries to place Goff within a regional context. "Mountain Republicanism," according to McKinney, emerged as a

\footnotetext{
${ }^{88}$ Lewis, Transforming the Appalachian Countryside, 213.

${ }^{89}$ Ibid., 66.

${ }^{90}$ Williams, Appalachia, 234.
} 
regional bond forged from pride, outside prejudice and fear during the Civil War. ${ }^{91}$ McKinney claims that this militarized politics to the extent that volunteers obtained military type ranks. He commented that in style the mountain based Republican organizations superficially resembled armies, but they operated more like Tammany Hall. ${ }^{92}$ Goff, as party leader, received the rank of General. Rankings were a typical method of bringing together southern highland Republican organizations according to McKinney, but the documentary evidence of such methods in the case of Goff is rather scanty. McKinney does point out that John Mason called politics "the battlefield of life,” but does this reflect the musings of an individual former officer or an entire political culture? ${ }^{93}$ Goff benefited much more from his actual position as United States Attorney than from a political "generalship." He also did not often seem to indulge in the habit of at least writing out orders to other party officials in the state. Only those higher up received that kind of "consideration." More accurate is the assertion that the organization ran somewhat like a city machine. Patronage represented the lifeblood of Goff's movement, but some presidents tried to build the party in breadth and not depth. President Hayes, for example, tried to use patronage to woo former Whigs and Union Democrats instead of Republicans in an ultimately futile attempt to construct a majority southern party. George Wesley Atkinson, later a Republican West Virginia governor, complained that this action would kill the state Republican organization. ${ }^{94}$ Atkinson’s assessment did fall short of the mark. The Republican Party limped through the 1870s, but it did survive. Goff's position as US Attorney combined with his personal wealth

\footnotetext{
${ }^{91}$ McKinney, Southern Mountain Republicans: 1865-1900, 7, 13.

${ }^{92}$ McKinney, "Southern Mountain Republicans and the Negro" Journal of Southern History 41 (November 1975): 498.

${ }_{93}$ McKinney, Southern Mountain Republicans,64.

${ }^{94}$ McKinney, "Southern Mountain Republicans and the Negro", 499.
} 
gave him influence over what federal jobs were available to the state party. These included not only the prize positions of collector of internal revenue, U. S. Marshal, and others in the U. S. Attorney's office, but also every postmaster position in the state.

Goff and state Republicans saw positive developments in the 1880s, both for Goff and the party itself. The damage to the Republican Party seen in the 1870s came as often from personalities as from issues. President Hayes, not exactly enamored with the power and position of his office, chose not to run for re-election in 1880. Although this probably stemmed from a natural distaste for power, Stalwart opposition to him could have created an embarrassingly complicated renomination process. Blaine expressed an obvious interest in the presidency in 1880. He faced several possible contenders including Ulysses S. Grant. Powerful leaders such as Senator Conkling gave substance to the possibility of Grant's returning to the White House. The St. Louis Globe Democrat predicted that "a man of iron" would replace "a man of straw.” Another writer claimed that looking back to Grant represented "the natural reaction of the Republican Party against the insipidity and imbecility of the present Administration." 95 Of course, this glossed over the scandals that had occured on Grant's watch. The Hero of Appomattox neither pushed for nor against his own nomination. Grant did want to run and return to the presidency; he enjoyed presidential power. He tried to dissemble by saying "I am not a candidate for any office, nor would I hold one that required any maneuvering or sacrifice to obtain."${ }^{, 96}$

When the voting started at the Chicago convention, Grant led all candidates. At the state level, the contenders maneuvered to try and gain the backing of delegates to the

\footnotetext{
${ }^{95}$ Smith, Grant, 614

${ }^{96}$ Ibid.
} 
national convention. Goff personally supported James G. Blaine, representative of a group derisively called "half-breeds" (those favoring some civil service reform) who took second place in the initial balloting. His support for a candidate who has backed reform of the patronage system must have come as a surprise to some. Others in West Virginia also strongly supported Blaine. Goff's future rival Stephen Elkins, still not yet a West Virginian, advised John Mason to "control the preliminary organization” of the state convention so as to assure their candidate of West Virginia delegate support. A Blaine victory, according to Elkins, was "your chance to make the state Republican in the next four years."97

Hayes’ presidency rewarded Goff with one of his few exposures to the national spotlight before he achieved fame in the 1890s as the truly elected, (at least as far as Republicans were concerned) governor of West Virginia. ${ }^{98}$ In the waning days of his only term, Hayes elevated Goff to the Cabinet as Secretary of the Navy. At the time, this was more about politics than national defense. Between 1865 and the mid-1880s, Congress approved very few naval related expenses, outside of keeping over five thousand patronage positions in the Navy Yards funded. Hayes subsequently accepted an unoffered resignation from that secretary after learning of corruption in his office. Presidents sometimes appointed Cabinet positions based upon political strategy as much as filling an advisory need. Goff represented an important state and got something of a reward for services rendered to the party, but had no real opportunity to make a strong mark. Goff's support of Blaine ended his chances of staying on after Hayes left Washington, despite the president's assurances.

\footnotetext{
97 Stephen Elkins to John Mason, May 21, 1880, Mason Papers.

${ }^{98}$ In 1888, Goff “won” the gubernatorial election but had his slender margin of victory eliminated by the discounting of black migrant worker votes.
} 
Hayes had appointed Goff to the Cabinet with the understanding that his successor would continue Goff in the job. Along the way, Goff developed a coherent understanding of national issues with which he could hammer his Democratic competition. Although his Cabinet experience acquainted him with the necessity of supporting a strong navy, Goff's real passion lay in his support of the protective tariff. He claimed to support a "moderate protective tariff as is absolutely essential to protect the American laborer in the pursuits of his business." ${ }^{, 99}$ Many manufacturers supported the tariff as well. Goff's quick exit from the job helped him in that he was free to finally triumph as a candidate for office again. In 1882 Goff secured election to the House of Representatives after serving his short stint as Secretary of the Navy. He had President James Garfield to thank for that "boost” to his career.

The two Republican presidents of the 1880s, Garfield and Chester A. Arthur, had to contend with mounting public debate over the patronage issue. The direction that their presidencies would take had an impact on almost every state party organization. Garfield, like many nominees in the pre-primary days, started off as a peripheral candidate and ended up the compromise solution. Certainly, his ability to charm a crowd helped win him the role as party nominee for president. Future Speaker of the House Joe Cannon recalled that Garfield "was a handsome and magnetic man, and one of the most eloquent orators who ever sat in the House.”" ${ }^{100}$ Garfield's speaking ability, affable manner, and long political tenure made him a good compromise candidate. His choice for Vice President, Chester Arthur, brought dismay to those who thought the former president of the Eclectic Institute would be a serious reformer. Garfield's nomination and

\footnotetext{
${ }^{99}$ Gerald Wayne Smith, "Nathan Goff”, 85.

${ }^{100}$ Joe Cannon and L. White Busby, Uncle Joe Cannon: The Story of a Pioneer American (New York: Henry Holt, 1927), 152.
} 
election returned the country to debates over patronage. Inevitably disaster would come from such a system where there were more men with such high opinions of themselves than there were rewards and plums. Garfield possibly enraged a deranged office seeker named Charles Julius Guiteau enough to get shot. He proclaimed to the world that, as a Stalwart, he preferred Arthur as president. The involvement of the issue of patronage in the murder of President Garfield stirred American anxieties on the issue to the proper point where reform was inevitable.

Arthur shocked the country by pushing hard for civil service reform. He said "For the Vice-Presidency I was indebted to Mr. Conkling, but for the Presidency of the United States my debt is to the Almighty.” Arthur's late blooming reform impulse ran him afoul with Congress. He vetoed pork barrel spending and a law prejudicial to Chinese, but found himself overridden. More successful were efforts in this period to modernize the navy and begin a building program that eventually made it one of the best in the world. ${ }^{101}$ The new president may not have admitted to any restraining earthly obligations, but he did go after past political opponents within the GOP. Goff's dogged support of Blaine in 1876 and 1880 cost him as Arthur used patronage to try and undermine the Republican leader. Although the president alienated some, he charmed others. A Marion County native and Kansas judge found Arthur the "most polished, suave, and courtly gentleman that has occupied the presidential chair in my day."102

Goff did have influential opponents within the West Virginia Republican Party during the 1880s. Francis H. Pierpont (who had returned from Virginia) and others found themselves on the outside looking in. He worked against Goff, but alienated Republicans

\footnotetext{
${ }^{101}$ Ibid, 415.

${ }^{102}$ Henry Clay McDougal, Recollections: 1844-1909 (Kansas City MO: Franklin Hudson, 1910), 97.
} 
also. Pierpont wrote President Arthur an endorsement of Mason, who was Goff's personal preference to succeed him as United States Attorney. Three days later Pierpont switched his endorsement to George Sturgiss, nominee for governor in 1880, with no explanation. ${ }^{103}$ Others described Pierpont in particular as a prickly and almost bitter character. Future Governor Atkinson (sometimes a sensitive person himself) asked "am I to be forever quiet and allow that old man to hound me to distraction?” Atkinson stoked the anger of the former governor and asked Mason to "please muzzle him.." ${ }^{104}$ Mason rebuffed opponents of Goff; the year before he tried to convince President Garfield to retain Goff as Secretary of the Navy to please West Virginia and the Southern states in general. ${ }^{105}$ Arthur himself refused the entreaties of both Pierpont and Goff by choosing W. H. H. Flick, who fell to paralysis during a court case in Martinsburg in March $1888 .^{106}$

The president attacked campaigns as well, but ran up against the strong reputations of those he would keep from office. Arthur marshaled resources against Goff during his successful congressional campaign in 1882. Also, Goff's lieutenant John Mason, fell to defeat in his own congressional race. Mason’s reputation among nationally known Republicans helped to make him one of the preeminent party men within the state, but he seemed to never contend for leadership of the West Virginia Republicans. Elkins extended an invitation to Mason to visit himself and Grant in

\footnotetext{
${ }^{103}$ Francis H. Pierpont to President Chester Arthur June 26, 1882, then June 29, 1882, Record Group 60, Department of Justice Records.

${ }^{104}$ George W. Atkinson to John W. Mason, March 8, 1884, Mason Papers.

105 John W. Mason to James Garfield, July 11, 1881, Mason Papers.

${ }^{106}$ Preston County Journal, March 29, 1888.
} 
1883. ${ }^{107}$ A year later, Blaine asked Mason to "please advise me as soon as you can as to the best method of making the fight in West Virginia.”108

One of Goff's problems during the 1880s lay in the Republican Party's inability to use Democratic divisions to gain majorities in the Legislature or win the Governor's Mansion. Business minded Democrats found themselves displaced by an agrarian surge in 1884 that elected “the fiery, but humorless orator,” E. Willis Wilson, governor. ${ }^{109}$ Wilson championed the rights of farmers and promised to address the issue of railroad price discrimination that always seemed to hit farmers the hardest. Wilson's election and maneuvering to block the re-election of Camden to the U.S. Senate lay bare the widening rift between Democratic factions within the state. Goff's Republicans failed to exploit the de facto division of their opponents into almost two separate parties. In 1888, this failure took on a personal aspect when Goff himself failed to win the battle over gubernatorial election results that originally declared him the winner. The Republicans still suffered from their own divisions, but were not nearly as afflicted as their foes..

The issue of patronage created complex political situations within the Republican Party. Chester Arthur was a Conkling Stalwart, a former chief of New York patronage, who became a Half Breed upon ascending to the presidency. Nathan Goff built up a West Virginia Republican organization loyal to himself through patronage, but strongly supported the Half Breed Blaine. The sudden civil service reformer, Arthur, tried to use patronage to weaken Goff because the West Virginia patronage king supported the candidate who was trying to lessen the impact of patronage. What looks confusing is actually the typical gap between personality, self-interest, and principle. If one looks for

\footnotetext{
107 Stephen Elkins to John Mason, August 13, 1883, Mason Papers.

${ }^{108}$ James G. Blaine to John Mason, June 18, 1884, Mason Papers.

${ }^{109}$ Williams, West Virginia: A History, 122.
} 
ideological purity or consistency, this would not be a good time period in which to search. Political self-interest normally gets priority and this was certainly a prime example.

Although at the time 1884 appeared to represent a failure for Goff and his party, in retrospect that year set the stage for eventual triumphs. The national party had tremendous confidence in its chances of "turning” West Virginia in 1884. It had a vision that coincided with its perception of Mountain State interests, a popular nominee in James G. Blaine, and energetic organizers such as Stephen Elkins. How could this team fail to attract a majority of supporters in West Virginia which, after all, was more of a border state than an offspring of Dixie?

The national party planned to divide the solid Democratic bloc in the South by focusing on economic issues. One party rule established itself very quickly in a region that saw partisan competition in many areas prior to the Civil War. Republicans had seen Blaine as a figure who could reconcile at least part of the South with the GOP, despite the fact that Southerners tended to prefer the incumbent Chester Arthur and his fount of political life giving patronage. ${ }^{110}$

James G. Blaine had a roman candle-like effect on the Republican Party in the 1870s and 80s. Every so often he launched a feud or campaign that lifted himself into the light of public opinion and scrutiny, but always fell to earth and flamed out. Rivalries and connections to corruption damaged Blaine’s image throughout his political life. No one worked harder to obtain the presidency in this period and few perennial losers inspired such deep loyalty and enmity. Individuals might run afoul of Blaine, such as Roscoe

\footnotetext{
${ }^{110}$ Charles Calhoun, Conceiving a New Republic : The Republican Party and the Southern Question 18691900 (Lawrence: University Press of Kansas, 2006), 201, 205.
} 
Conkling did, but he saw the party itself as sacrosanct, somewhat along the lines of a political church. Blaine waded through railroad scandals and feuds with other Republican leaders because of the almost universally acclaimed magnetism of his personality. Supporters called him unblushingly “the magnetic man” and even more ostentatiously "the plumed knight.” Privately, Blaine indulged in powerful neuroses such as hypochondria and intense self-pity. His ambition masked insecurity and a wide range of powerful emotional responses. The nominee in 1884, like many party men, had little vision. However he understood the value of political work and gained a reputation for it like few others. ${ }^{111}$ Blaine failed to best Hayes and Garfield for the nominations in 1876 and 1880, but won nomination in 1884 .

Blaine believed that a vision of economic prosperity could breach the walls of the Solid South. The Civil War left many districts destitute and poverty remained a defining feature of many ravaged areas until at least World War II. No Marshall Plan helped to rebuild this region until Cold War defense and space appropriations made their way there. Promises of development represented a reasonable path to rebuilding the GOP image there. West Virginia appeared to Republicans as an ideal target for its economic message of development and protection because of the expanding extractive industries. Historian Charles Calhoun called this campaign to sever West Virginia from the Democratic bloc a failure. He was right about 1884 itself, but in terms of its impact on West Virginia it constructed the foundation for successes in the 1890s. ${ }^{112}$

\footnotetext{
${ }^{111}$ Mark Wahlgren Summers, Rum, Romanism, and Rebellion (Chapel Hill: University of North Carolina Press, 2000), 61-62.

${ }^{112}$ Ibid, 206.
} 
Protectionism was one way to pry Democratic votes away by appealing to the people's interest. ${ }^{113}$ It made sense to both labor and business, if not always consumers. In 1884, Republicans reaffirmed their identity as the party of protection, helping to attract voters and divide the opposition in states such as West Virginia. Nathan Goff embraced the issue as his own and delivered thundering addresses on the subject, such as when he used the topic as a weapon against President Grover Cleveland in the House of Representatives in 1888. In a speech entitled “American Markets For American Labor,” he stated that "the moment one of our industries is self-sustaining" it "receives the President's enmity and he at once suggests the pruning knife of the tariff reform."114 Even state level Republican leaders pushed the tariff issue. Atkinson produced a pamphlet on the issue that exhorted in Wesleylike language that "he that provideth not of his own household is worse than the infidel.” The future governor also summoned the specter of Anglophobia, accusing Britain (the main competitor to American industrial and mining interests) of pretending to be a Christian nation while committing "all crimes in the calendar of crimes." 115 Protectionism gave Republicans an issue to gain votes at the same time as it initiated a severe schism among West Virginia Democrats. Henry Gassaway Davis had helped to elevate William L. Wilson to the House of Representatives, but the industrialist soon broke with the emerging leader of the "tariff reform” movement. ${ }^{116}$ Goff's position as one of protectionism’s front line warriors also earned him valuable roles in the national Republican hierarchy. Democrats feared Goff's

\footnotetext{
${ }^{113}$ Summers, The Gilded Age, 208-9.

114 “American Markets For American Labor” Nathan Goff Speech to House of Representatives, April 27, 1888, Goff Papers.

${ }^{115}$ George W. Atkinson, The ABC of the Tariff and the Records of the Republican and Democratic Parties Thereon (Wheeling: Daily Intelligencer Press, 1884) 6, 17.

${ }^{116}$ Williams, West Virginia and the Captains of Industry, 56-57.
} 
growing clout, expressing to their leadership that "Genl. Goff as Chairman of the Republican Congressional Committee will have unlimited means at his disposal and will spend it freely. They are all thoroughly in line and organizing well."117 Money and a popular position helped Republicans mount their best challenge in nearly two decades.

Goff followed the trends of political party construction, trying to use what patronage he could access to build the organization. He differed from other bosses mainly in the poverty of the tools with which he started his work. The force of his reputation, charisma, and wealth helped maintain him in his position despite the presence of perpetually irritable chieftains, some of whom dated to before Goff's leadership. Unfortunately Goff played the role of the coach who carefully built the program during trying years, got fired, and found that his successor enjoyed almost immediate success from the foundation he built. His greatest challenge would come in 1888. In this year Goff found himself maneuvered into a gubernatorial contest he did not seek by a challenger to his authority over the West Virginia Republican Party.

${ }^{117}$ R. Stalnaker to Johnson Camden, June 4, 1886, Johnson Camden Papers, West Virginia and Regional History Center, West Virginia University, Morgantown, West Virginia. Hereafter cited as Camden Papers. 


\section{CHAPTER FOUR}

\section{THE REPUBLICAN PRESS}

Republican activities in the post-Civil War period did not only center around the party moves and personalities. They needed allies to help carry their message to the voters. Media and politics may appear to be entirely separate institutions, but interactions with the public and each other in a free society result in an intricate and sometimes very intimate intertwining. In the case of nineteenth century West Virginia, this effect becomes closely evident. Sometimes the goals of the press triumphed, sometimes those of politicians did, but often these ambitions are one and the same particularly among the partisan press. Very few newspapers sat on the proverbial political fence in those days; they sided with either of the major parties. Republican press in West Virginia often reflected the first part of the Preston County Journal's motto “Onward and Upward,” but not always the second half “True to the [party] Line."1 West Virginia Republican editors enjoyed establishing their own lines which they regarded as "true," but this did not always reflect the national or state party interest or goals. Editors came from a variety of backgrounds, held different perspectives, and harbored ambitions of their own. They assisted and clashed with politicians of their party based upon how they viewed the world and their own responsibilities.

Newspapers across the country in the mid to late $19^{\text {th }}$ century relied upon political news and party assistance to survive. In an era before professional sports and soap operas, the trials, tribulations, and outright spectacle of political life provided entertainment clad in the gowns of civic virtue and participation. Journalism rarely in

\footnotetext{
${ }^{1}$ Preston County Journal, 1866-93. The masthead on every edition in this period carried this slogan.
} 
American life rose to the idealistic level of the objective "fourth estate." Some newspapers later in the century proudly embraced the concept of crusading on issues certain to draw public attention through sensationalism. Others tried to draw readers by encouraging "humor, sentiment, and originality.”” Journalist William Allen White described his own business as "beggar and blackmailer" in country towns, but also "one of the major industries” in these same villages. ${ }^{3}$

Even though political partisanship remained important, direct ownership of newspapers by the parties declined by mid-century. However parties and papers existed in a symbiotic relationship because prior to the Second Industrial Revolution, they did not generate profits without assistance. As part of the "spoils system,” papers allied themselves with presidential administrations to receive lucrative printing contracts. The parties themselves might patronize papers in the same fashion. A lucrative market existed for the printing of fliers, brochures, and other advertising materials. Industrialism's byproduct of more money and better education helped the newspapers eventually become increasingly financially independent. In 1840 2,200 newspapers circulated every day. By 1904 that number jumped to 8,007. ${ }^{4}$ During this time the figure of the editor-publisher emerged. By 1869 many Republican papers had released themselves from dependence on the party and adopted a more independent line. Men such as Horace Greeley, “a strange combination of fuzzy idealist, fighting reformer, and crusading journalist,” built metropolitan dailies into political forces that increasingly

\footnotetext{
${ }^{2}$ Scott Compton Osborn and Robert Phillips Jr., Richard Harding Davis (Boston: Twayne Publishers, 1978), 34, 35, 37.

${ }^{3}$ William Allen White, Autobiography (New York: Macmillan, 1946), 313

${ }^{4}$ Michael McGerr, The Decline of Popular Politics: The American North 1865-1928 (New York: Oxford, 1986), 15, 113, 108.
} 
bucked the regular party line. ${ }^{5}$ Greeley himself, as was earlier described, ran for the presidential nomination against fellow Republican Ulysses S. Grant in 1872. The independent powerhouse newspapers of the post-Civil War era gave way to the syndicates ruled by William Randolph Hearst and Joseph Pulitzer who wielded influence across the nation.

West Virginia’s Republican partisan press performed a variety of functions that helped it build and maintain the party organization. First it helped to introduce the party into a region that was strongly Whig and Democratic. It elevated members of its own profession into important party and elected positions, while also assisting the advancement of approved political figures from outside of journalism. Newspapers played a role in lobbing rhetorical ammunition against the Democrats and their press while also trying to maintain unity in the Republican cause. This system did not always work perfectly as "kickers" sometimes appeared in various times and places to disrupt the will of the party leadership. ${ }^{6}$ Often they found some press support for their rebellion. Newspapers generally adhered to a partisan ideology, usually supporting similar state and national issues such as the retention and expansion of a protective tariff and continued industrial development. In their shaping of the political and by extension economic destiny of the state, the Republican partisan press played a tremendous part in helping to produce the West Virginia that greeted the twentieth century. Comparing West Virginia’s partisan press with other publications such as the New York Times does not present much of a contrast when it comes to tone and methodologies. However, historians only rarely have examined the role of the press in early West Virginia politics including

\footnotetext{
${ }^{5}$ Felknor, Political Mischief, 54.

6 "Kickers" were individuals or groups that rebelled against the party leadership and its followers, generally known during periods of factional rebellion as "Regulars."
} 
the extent of its ability to shape opinion, the roles it filled, and the influence it held over state political development.

The Republican press began in West Virginia when Archibald Campbell and John McDermott assumed control of the Wheeling Intelligencer from Democratic ownership in 1856. Campbell was one of a few figures in the region who represented a "notable exception" to the general consensus that abolitionists were to be hated and their influence feared. Many northwestern leaders such as Waitman T. Willey, who did not sympathize with the South or rebellion, tended to support John Bell’s Constitutional Union Party of former Whigs. ${ }^{7}$ By 1860, Campbell had cast his allegiance with the Republicans. This reflected principle more than an accurate calculation of power. His newspaper consistently attacked the "slave power" and the "spirit of the old cavaliers" that Campbell claimed retarded the growth of western Virginia. The Intelligencer specifically targeted the new German community which it hoped would convert to Republicanism. ${ }^{8}$ Although some have asserted that the newspaper was not a Republican organ at the very beginning of Campbell's editorship, it is important to note that the paper came into his hands during the year of the first Republican presidential campaign. ${ }^{9}$ The publication demonstrated its early Republicanism by expressing strong opinions against the Lecompton Constitution granting slavery in Kansas, calling itself the “opposition” paper, and by 1859 comparing itself to the Republican Boston Bee.

\footnotetext{
${ }^{7}$ Charles Ambler, Waitman T. Willey (Huntington WV: Standard Printing, 1954.), 5, then 33-34.

${ }^{8}$ Ken Fones-Wolf, "Caught Between Revolutions" in Ken Fones-Wolf and Ronald Lewis ed., Transnational West Virginia (Morgantown: West Virginia University Press, 2002), 30-31.

${ }^{9}$ Donovan Bond, “How the Wheeling Intelligencer Became a Republican Organ,” West Virginia History 11 (April 1950) : 160.
} 
Prior to the Civil War, the Intelligencer provided western malcontents with a forum to air their grievances against the eastern dominated state government. ${ }^{10}$ Certainly by the time Abraham Lincoln ran for the presidency the Intelligencer had developed into the "right arm of our [statehood] movement."11 Campbell himself joined the Lincoln for president movement, representing Western Virginia in the Republican National Convention in 1860. Unthreatened by combat operations, Wheeling and its paper developed free from the fear and terror of marauding armies and desperate guerillas that gripped the remainder of the state.

The Wheeling Intelligencer promised to be "independent and liberal" and the postwar period saw some signs of this. ${ }^{12}$ Independence to Campbell did not mean remaining objective in politics. Like Greeley and Whitelaw Reid, Campbell looked to become in Reid's words “the master, not the tool, of party."13 Newspaper editors joined with magazine publishers such as George William Curtis of Harpers Weekly to form a quasi-intellectual conscience for the Republican Party. Such men often bucked the "Regular" line, and, in 1884, went so far as to form the "Mugwump" movement and support Grover Cleveland for president; of course in that year, Roscoe Conkling quietly joined reformers in their opposition to Blaine. ${ }^{14}$

Like other editors, Campbell developed into a powerful figure, serving on the Republican National Committee from 1864 to 1868 and on the Electoral College that ushered Grant into the White House in the latter year. Campbell relinquished his duties

\footnotetext{
${ }^{10}$ Ronald Lewis, Transforming the Appalachian Countryside (Chapel Hill: University of North Carolina Press, 1998), 55.

${ }^{11}$ Granville Davisson Hall, The Rending of Virginia: A History (Chicago: Mayer and Miller, 1902), 386.

${ }^{12}$ Bond, "How the Wheeling Intelligencer ..., 163.

${ }^{13}$ McGerr, The Decline of Popular Politics, 114. Whitelaw Reid and his ilk remained unabashedly partisan, however, he, Pulitzer, and others of their stature remained highly respected for the quality of political journalism they produced. Summers, Party Games, 77.

${ }^{14}$ Eugene H. Roseboom, A History of Presidential Elections (New York: Macmillan, 1958), 273.
} 
as editor of the Intelligencer in the late 1860s, but did remain active in Republican politics. Even without Campbell, the paper continued as a commanding voice of state Republicanism. The Intelligencer's “liberal” inclinations led him into an 1872 conflict with the national party leader, President Ulysses S. Grant. In the weeks leading up to the splinter convention, the paper argued that a Grant machine had manipulated county nominating conventions by "packing” them with delegates not elected by their townships. It also published speeches by Senator Charles Sumner proclaiming that "if the campaign can be made a personal one between the Big letter G and the little letter G-I am for the Big G-Horace Greeley [one of the main candidates promoted in Cincinnati].”15 The Intelligencer also posed the question "is it a crime for a citizen of the United States to believe that GRANT ought not be the next president and to labor to defeat him?”16

Much of the opposition to Grant came from an elitist upper crust of newspaper editors and writers, intellectuals, activists, and the perpetually antagonistic Adams family "who had tired of cigar smoke in the White House." ${ }^{17}$ In this case, the Intelligencer did not serve the Regular party organization as much as a faction trying to win control. Liberals wanted to reconcile quickly with the South, and many agreed with Democrats that the freedmen had not proved worthy of the cost paid for their release from bondage. It is easy to understand why the Liberal movement found traction in the border states like West Virginia, although the Intelligencer did not generally articulate the malevolent level of racism expressed by Greeley who told Southern blacks "Root, hog, or die.”18 Its editors still saw the support of West Virginia blacks as crucial to state Republican

\footnotetext{
${ }^{15}$ Wheeling Intelligencer, May 21,1872.

${ }^{16}$ Ibid.

${ }^{17}$ Smith, Grant, 548. The Adams connection alone should have told the Liberals that their cause was probably doomed.

${ }^{18}$ Ibid, 549.
} 
candidates. Grant did not personally campaign, but his supporters flooded areas like West Virginia and rendered his nomination and eventual reelection a formality. In June 1872, the Intelligencer complained that "the machinery of the party throughout the country is . . . completely in the hands of Grant.” However, after the national convention nominated the general, Campbell obligingly placed the official ticket on the editorial page masthead and began to support the party. When it came down to it, this publication put party first, helping to maintain the organizational structure even by supporting a figure, Grant, whom it did not like. By November, the Intelligencer even chastised recalcitrant Liberals such as Francis Pierpont to "support the reelection of President Grant.” It argued that “a President Greeley would have a Democratic candidate” and despite admitting "we felt the same reluctance [for Grant] and gave it free expression” it now endorsed "the brave, honest, modest, able man."19 Later the paper gave free expression to other ideals that may have struck some as radical, but did come to pass in the next century. Not only did it support the temperance movement, but it championed woman's right to vote and spoke of that development's inevitability. In 1888, the Intelligencer informed its audience, "the hand that rocks the cradle today wields the power that may bring about a great revolution tomorrow.,20

While the Wheeling Intelligencer represented the party at the state level, partisan newspapers had exploded in support of the Republican Party in the years after the Civil War. Many smaller operations in isolated regions, “one horse, pap-fed bureau edited sheets” continued to rely upon subsidies. Some small town papers literally lived and died

\footnotetext{
${ }^{19}$ Wheeling Intelligencer, June 2, and November 2, 1872.

${ }^{20}$ Ibid, January, 71888.
} 
based upon whether or not their party held the presidency and small town editors often were rewarded with postmaster positions. $^{21}$

One of the most respected of the local publications was Kingwood's Preston County Journal. It proved another example of how a newspaper editor with ambition can rise from obscurity into power. Press outlets could help build the career and reputation of politicians and party leaders, and the Journal produced one of the Republican Party’s most able, William Mercer Owens Dawson. The Journal started circulation in 1866 and did fairly well. Its subscriptions included the "leading citizens of Kingwood” and operated out of a rent free office in the courthouse. Its initial editorial by Levi Klauser stated that "our paper is calculated to benefit every man in the county by having the interest of the whole county constantly, earnestly advocated and its mineral, agricultural, and other wealth pointed out to capitalists at a distance.”22

Initially, the Journal adopted the philosophy of development common to many Republican and Democratic papers of the period. In this and other ways, the newspaper served the purpose of promoting the party principles to the general public. Like many other local papers, the Journal leapt into the struggle over the redeeming of the state by the Bourbon Democrats in 1872. In February of that year, the paper published complaints about the Democratic Legislature changing the name of towns such as “Averill” because it was named after a Union general. It also defended itself and the county party against general accusations of “corruption in office” and establishing a "ring.” An editorial explained another general function of the partisan press, "it is our simple duty to defend that party and its representatives against the base calumnies of its

\footnotetext{
${ }^{21}$ Mark Wahlgren Summers, Party Games (Chapel Hill: University of North Carolina Press, 2003), 76. ${ }^{22}$ Patricia Ann Zinn, "History of the Preston County Journal" West Virginia History Vol 32 No. 4 (July 1971) 245-266, p 245.
} 
enemies.” Of course, when possible, it launched attacks against the Democrats and their advocates. On February 29, it cried "Fraud! Fraud!! Fraud!!!” and published an intensive expose about irregularities in the publishing of documents pertaining to the 1872 constitutional convention. The next month it blasted a Democratic plan to divide Preston County and included the partisan accusation that such a division was proposed to weaken Republican strength in that area. ${ }^{23}$ As spring turned to summer, the Journal maintained its opposition to the Bourbon constitution. It also did not fight the state party's executive committee decision to pursue a passive party in state elections that November. ${ }^{24}$

Klauser died of typhoid in 1871 and the paper fell into neglect until its publisher, James B. Chaffin, handed the editorship to Dawson in 1873. Dawson brought dynamic editing to the Journal and used it as a vehicle to advance what were then called progressive causes three decades before they grew fashionable to the majority of the Republican Party. This serves as one example of individual political figures using the press to try to shape the party itself. He also advanced his own political ambitions through the constant expression of his ideals. In this manner, he emulated men such as Greeley, Grant’s Vice President Schuyler Colfax, and James G. Blaine. Dawson, an "unusually efficient” self-made man grew up working in the Cranberry (later Terra Alta) region of Preston County. Throughout the 1860s he worked as a cooper's apprentice and a clerk while making contributions to the Journal. At the age of twenty he became editor. ${ }^{25}$ Dawson soon showed a wit not uncommon to local partisan editors by promising that "No man who pays regularly and in advance for his county paper was ever

\footnotetext{
${ }^{23}$ Preston County Journal, February29, and March 28, 1872.

${ }^{24}$ Ibid, June 20, 1872.

${ }^{25}$ George W, Atkinson, Prominent Men of West Virginia, (Wheeling: W.C.Callen, 1890), 483. Also see S.T. Wiley, History of Preston County (Kingwood: Journal Printing House, 1892), 262.
} 
bitten by a mad dog."26 More importantly, he quickly proved to be an advocate for progressive causes when he blasted the Board of Education for allowing "a deficiency of fifty qualified teachers.” Even twenty years later he still showed an interest in public education when he chided local leaders that "the best men are not too good for presidents and members of the Board of Education.” Dawson also encouraged the schools to increase attendance and decrease "incompetence and inefficiency."27 Newspaper advocacy of better education ought to come as no surprise as it presents the ultimate example of enlightened self-interest.

The editor brought other issues to the pages of his newspaper. In 1880 Dawson responded to a Democratic attack on Republicans' inclusion of blacks in the state convention by saying, "Oh brother, it is only a case of sour grapes with you. The Republican party elevated the colored individual from being a thing to a man with all the rights that belong to manhood., ${ }^{28}$ He also used his editorial bully pulpit to press for better roads and temperance. Interestingly, Dawson campaigned against the smoking of "paper cigarettes." He stated "some law should be enacted whereby the manufacture and sale of this article could be prohibited."29

Dawson's political career only started eight years after his first full time stint as editor. While some in later times might see a conflict between running a moderately circulated partisan newspaper and taking a role in state government, Dawson did not. Upon entering the state senate, he immediately started proposing reforms in the regulation of rail traffic. He offered a resolution to ask the state congressional delegation

\footnotetext{
${ }^{26}$ Preston County Journal, October 25, 1873 and April 9,1891.

${ }^{27}$ Ibid, October April 9, 1891.

${ }^{28}$ Ibid, March 25, 1880.

${ }^{29}$ Ibid, January 8, 1891.
} 
to regulate railroads on a national level. ${ }^{30}$ Dawson served as state senator for eight years, but also dedicated his efforts to working in several capacities for the state party organization. This advancement in the party hierarchy coincided with the general rise in the fortunes of Republicans as the Democrats split into industrial and agrarian factions represented by 1888 in the persons of Standard Oil associate Johnson Camden and Governor E. Willis Wilson, respectively.

In 1896 Dawson, now heading the state party, could assure Republican chief Stephen B. Elkins that Senator William Stewart of Nevada would have several good places to speak in the Mountain State and guaranteed large audiences. ${ }^{31}$ Dawson continued to play a role in the formation of reliable press outlets, aligning himself with the notoriously corrupt Kanawha County "Hog Combine” ring to help form the Charleston Mail Tribune. ${ }^{32}$ By 1900 he had become chairman of the state Republican Committee and could send detailed reports to now U.S. Senator Elkins about prospects for candidates all over the state. Dawson warned Elkins that the Republicans would not carry several counties and also advised him on matters of patronage when he penned, "We got Lew Martin ... He wants an office very, very, very, bad ... I cannot make it badder than it is; and he wants it instanter [sic]. ${ }^{33}$ Dawson retired from his editorship in 1891, supposedly for health reasons, but his stature had developed and the state party regarded him as a capable leader. In 1904 his turn came; according to a later journalist, "there seem to be two paths that lead to the governor's seat in West Virginia. One is by

\footnotetext{
${ }^{30}$ State Senate Journal, 1881 W.M.O. Dawson Papers, West Virginia and Regional History Collection, West Virginia University Libraries, Morgantown, WV. Hereafter referred to as "Dawson Papers"

${ }^{31}$ W.M.O. Dawson to Stephen B, Elkins, April 12, 1900, Elkins Papers.

32 John Alexander Williams, West Virginia and the Captains of Industry (Morgantown: West Virginia University Library, 1976),83.

${ }^{33}$ W.M.O. Dawson to Stephen B. Elkins, April 23, 1900, Elkins Papers.
} 
the newspaper route and the other is by the law profession.”34 Dawson ran for the office with both achievements under his belt, and he succeeded. His career ended with political power, but started with his assumption of the Preston County Journal bully pulpit.

Interestingly, upon his resignation of the editorship he drew that rarest of compliments, one from the Democratic town rival. The West Virginia Argus in a story about a supposed Dawson gaffe, printed that they had "no desire to misrepresent Senator Dawson for, apart from his politics, he is a clever gentleman and one whom this reporter esteems as a friend.”35

West Virginia’s partisan Republican press did not merely elevate members of its own profession into political leadership. Stephen B. Elkins cast a large shadow over West Virginia politics from the moment he stepped upon the state stage in 1888, but it is difficult to disentangle whether the press influenced his rise or vice versa. Certainly the press worked hard to promote Elkins as an effective leader for the state party. Elkins’ entry into state politics drew strong and enthusiastic responses from Republican editors in public and behind the scenes. The Wheeling Intelligencer editorial staff desperately wanted to use an economic development convention in February of 1888 to promote Elkins. One of the editors, Charles Burdett Hart, strongly advised Elkins to attend and offered to have the Chamber of Commerce "arrange for the scheme.”36 He assured Elkins that the railroads had offered assistance (presumably by providing passes for VIPs) and that the turnout would be huge. Hart emphatically stated “you will fit in very

\footnotetext{
${ }^{34}$ West Virginia Hillbilly, January 12, 1957.

${ }^{35}$ West Virginia Argus, October 4, 1888.

${ }^{36}$ Hart purchased Archibald Campbell's interest in the Intelligencer on November 15, 1882 and succeeded Campbell as editor. In a reversal of the modern direction of journalists, Hart moved from the large market of Philadelphia to the smaller in Wheeling. A Democratic paper referred to Hart as "the able editor of the Intelligencer from that cesspool of political iniquity—-the city of Philadelphia. Wherever republican methods go they are corrupting and demoralizing.” Barbour Jeffersonian, August 6, 1884.
} 
snugly. This thing you must do., ${ }^{37}$ Of course Elkins had hedged his bets by obtaining a substantial share of the stock of the Wheeling Intelligencer, thus purchasing the good graces of the most influential Republican paper in the state. ${ }^{38}$ The convention attendance of Elkins marked his entrance into state politics (the Intelligencer saw fit to publish his speech there in five languages) and also announced an increased economic presence. It helped to initiate the relatively congenial struggle with reigning party boss Nathan Goff Jr. that eventually ended in Elkins' triumph and saw him also pledge to increase investment in the state. ${ }^{39}$ Almost immediately afterwards, he established the terminus of his West Virginia Central Railroad at the future town of Elkins in Randolph County and looked for avenues of expansion, making good on his promise.

Editors tirelessly, especially near elections, tried to maintain party cohesion as the election contests took place. Those who broke party lines in legislative affairs could find themselves called out by an editor, an example being Dawson's leveling of criticism towards Republican “traitors and scoundrels” supporting Camden’s bid for the U.S. Senate. Although the Preston County Journal orchestrated the attack, the impact was doubly blistering because of Dawson’s position in the state party apparatus. Years later, the Charleston Daily Mail warned two months prior to the election of 1902 that "harmony among the leaders as well as the rank and file must be the watchword from now on to the end of the campaign., ${ }^{40}$ The Kingwood New Era, a brief Republican

\footnotetext{
${ }^{37}$ Charles Burdett Hart to Stephen B. Elkins, February 6, 1888, Elkins Papers.

${ }^{38}$ Gordon McKinney, Southern Mountain Republicans: 1865-1900 Politics and the Appalachian Community (Knoxville: University of Tennessee Press, 1978), 113.

${ }^{39}$ Ibid. 152. Goff was a high ranking Union officer, a former congressman and Secretary of the Navy, and a national figure in his own right. Elkins and Goff's struggle for party control remained remarkably amiable and ended when Goff was appointed to the federal judiciary.

${ }^{40}$ Charleston Daily Mail, September 25, 1902.
} 
competitor of the Preston County Journal promoted the cause of unity more succinctly by stating “death to kickers and bolters." 41

Some editors worked behind the scenes to try and promote party unity, such as when the Fayette Journal's G.C. McIntosh in 1900 tried to help Elkins patch a feud that had erupted between Justus Collins and out of state landowner Thomas McKell, supposedly over the placement of a post office. ${ }^{42}$ Republican editors carefully warned their readers about supposedly nonpartisan news outlets that might sway public opinion and readership, such as when the Preston County Journal alerted its readership to the Grafton Sentinel by attacking its motto; "independence in all things, neutrality in nothing is a cover for Democratic leanings. ${ }^{\text {} 43}$ On the other hand, Republican papers gleefully encouraged divisions in the opposing side, as reflected in this Daily Mail editorial that read, “you can’t fool even Democrats all the time ... in the past few years the boys have been dropping out of the Democratic procession in numbers and joining the Republican parade. ${ }^{44}$

Many newspapers after the Civil War tried to walk a fine line between party loyalty and editorial independence. They did not want to be seen as ciphers for the party. Just as the Intelligencer in 1872 supported large kicker movement against Grant, state papers could do so as well. When Romeo Freer in 1900 launched his kicker campaign for governor against Regular Republican A. B. White, he had the support of the Horton Courier which stated that "enthusiastic" West Virginians went to Washington "for the purpose of booming Representative Freer for Governor.” It was quick to quote State

\footnotetext{
${ }^{41}$ Kingwood New Era, October 5, 1888.

${ }^{42}$ G.C. McIntosh to Stephen B. Elkins, April 30, 1900, Elkins Papers.

${ }^{43}$ Preston County Journal, March 7, 1874.

${ }^{44}$ Charleston Daily Mail, September 25, 1902.
} 
Senator Stark Baker’s claim that “there is no anti-administration nor anti-Elkins

sentiment." 45 A.B. White complained that "the course of the State Journal is very hostile to me by creating the impression that Freer is having a walkover." ${ }^{\text {"46 }}$ Newspapers expressed dissention over other issues as well.

Geography often created friction, especially in a party dominated by centers of power in the northern part of the state, such as Wheeling and eventually Elkins. When U.S. Senator Nathan B. Scott (an Elkins ally) tried to secure a visit by then President Theodore Roosevelt to Wheeling, the Charleston Daily Mail complained "that is alright from the Wheeling standpoint ... it creates more of a desire than ever for a [U.S. Senator] who will take an interest in this section of the Commonwealth." ${ }^{, 47}$

Serious clashes exploded on the local level from time to time, as in the McCormick-Dawson rivalry in Preston County during the election of 1888. This conflict illustrated an example of the occasional interconnection of press and party infighting. The Dawson owned Preston County Journal and the Samuel P. McCormick allied Kingwood New Era served as the mouthpieces both sides used to attack each other, though both professed to be the true standard bearers of Republican belief. The immediate reason for the rift lay in the Republican nominee for Circuit Clerk. A longtime officeholder died, leaving the nomination open relatively close to election day. The background to this disagreement lies in a McCormick challenge to Dawson's control over the county party apparatus. McCormick actually chaired the county executive committee while Dawson at the time was finishing out his term in the state senate and seeking a state office in the party. The county executive committee met and selected Dr.

\footnotetext{
${ }^{45}$ Horton Courier, February 15, 1900, Elkins Papers.

${ }^{46}$ A. B. White to Stephen B. Elkins, February 5, 1900, Elkins Papers.

${ }^{47}$ Charleston Daily Mail, September 3, 1902.
} 
James Cox as the party's candidate. Here the lines between kickers and regulars blurred. Although the technical party leadership lay with McCormick, Dawson still controlled many of the strings of de facto power. Both sides claimed the status of "regulars" through their respective newspapers.

The New Era called for all Republicans to support the ticket "rather than gratification of his own selfish schemes or prejudices.” He noted that, "Republican success is of greater moment than the triumph of any man or faction., ${ }^{48}$ Depending on which side the reader takes, he or she could consider the call for party unity altruistic or self-serving, but it certainly served the purpose of reinforcing the legitimacy of the McCormick faction's candidate. As for the Dawson faction, the Journal accused the committee of overstepping its bounds because, as it asserted, the majority of the party did not "wish them to exercise such authority." 49 Instead, the faction called a special convention that nominated John W. Watson for the office less than two weeks before the election, a move "heartily endorsed" by the Journal. The Dawson faction, however, admitted the irregularity of its own action in the defensive statement: "now we reckon it is just as bad to 'pack' a committee and try to forestall its action as it is to 'set up' a convention., 50

Both sides appealed to state chair W. J. W. Cowden, whose noncommittal replies did not clarify the state party's position. As a result, the papers pressed their cases against each other as furiously as against the Democrats and the attacks grew more personal. The New Era responded to charges that McCormick used his position as chair of the committee for his "personal benefit" by stating that the insinuation "comes with ill

\footnotetext{
${ }^{48}$ Kingwood New Era, October 5, 1888.

${ }^{49}$ Preston County Journal, October 11, 1888.

${ }^{50}$ Ibid, October 25, 1888.
} 
grace from a man who has done that very thing for the past ten years ... for eight years he played the dictator." ${ }^{51}$ It reminded voters days later to "beware of kickers, bolters, and stirrers up of strife--McCormick and his followers are for the Regular ticket: All insinuations and charges to the contrary are false. Vote the straight ticket.” In the same issue, the New Era accused Dawson of perpetrating voter fraud by printing false voting tickets in blue ink instead of black and called it "one of the most despicable schemes ever resorted to, to defeat the regular ticket." ${ }^{\text {,52 }}$ The Journal vehemently denied that blue or black ink represented a legal obstacle to voting. ${ }^{53}$ Directly after the election results confirmed the Dawson candidate to be the victor, the New Era called Watson "a good scribe” but claimed “Dawson has been cracking his boss whip so long that he can’t quite quit the practice.”54 November saw a cessation of intra-party strife, at least between the newspapers, in the face of the impending struggle over the results of the governor's race.

When interested in doing so, another manner of preserving party unity lay in the development and maintenance of ideology with special attention paid to economic issues. First and foremost for Republicans lay the issue of preserving, and, if possible, expanding the protective tariff. Since the days when the Founding Fathers sat as members of the new Republic, the tariff had provided the country with a divisive issue. With few other ways open for taxation until the passage of the Income Tax Amendment, this was one of the main methods by which the federal government received money to operate. Some sort of tariff had to exist; the question was how extensive.

\footnotetext{
${ }^{51}$ Kingwood New Era, October 26, 1888.

52 Ibid, November 2, 1888.

${ }^{53}$ Preston County Journal, November 1, 1888.

${ }^{54}$ Kingwood New Era, November 16, 1888 then November 9, 1888.
} 
Republicans created a permanent and powerful protective tariff. This provided little help for Americans trying to penetrate foreign markets because of reciprocal measures by other industrial countries, but it did protect an American market that, at least at this time, seemed to be all that American industrial productive capacity required, so far as Republicans were concerned. Nathan Goff expressed the Republican stance eloquently before the House of Representatives in April, 1888 when he stated "the moment one of our industries is self-sustaining, is in a healthy condition ... then it makes thereby and receives the President's [Cleveland's] enmity and he at once suggests the paring knife of the tariff reformer."

For Republican newspapers, it came down to a struggle between the Democratic Party and the industrial worker, and they were thrilled to play the part of defending the latter. This did not mean that the ulterior motives of protecting West Virginia coal operators against competition from Canadians who happened to produce closer to the allimportant Northeastern market did not exist. Stephen Elkins feared Nova Scotia operators getting control of the northeastern market and the rights to produce for Britain's White Star Lines. ${ }^{56}$ One southern West Virginia paper's devotion to this issue led it to actually call itself the Southwestern Protectionist. A strong angle through which the press attacked the opponents of the tariff lay in constant attacks upon British industrialists whom they portrayed as exploiters of the workers in an effort to keep prices low. The Kingwood New Era accused the Democrats of impure allegiances to Great Britain and that workers from that country fled to the United States to find better conditions. ${ }^{57}$ The

\footnotetext{
${ }^{55}$ Nathan Goff Speech “American Markets for American Labor, April 27, 1888” (Washington: House of Representatives, 1888), 4.

${ }^{56}$ Stephen B. Elkins to Henry Gassaway Davis, March 20, 1894, Elkins Papers.

${ }^{57}$ New Era, November 2, 1888.
} 
Intelligencer helpfully produced a small booklet by Republican leader and future governor George Atkinson that insisted "basically free trade with Britain ruins prosperous nations because they exploit workers for abysmal pay.” He cited Turkey and India as examples. ${ }^{58}$ Atkinson also quoted the Bible as evidence to bolster his claims about the righteousness of protection when he cited "he that provideth not of his own household is worse than the infidel." 59

This type of sentiment carried some weight with workers, at least for a time, as evidenced by the 1870 headline from the Miners' Journal “Poor Man Read: Democratic Inconsistency: They Despise Poor Men.”60 Democratic rivals fought back and sometimes had fun with the almost obsessive attention granted to the subject of protectionism by Republicans. Parkersburg's Weekly Sentinel chided its crosstown rival, the Journal, by requesting that it reprint its "ponderous and oppressively dull potatoe (sic) editorial of last fall.” It continued by referring to it as "one of the wondrous productions of the tariff campaign and we would be pleased if our contemporary would spare space for its reproduction at this time." ${ }^{\prime 61}$

Another issue that resonated strongly with Republican editors was the desire for development that many shared in West Virginia at the time. Apart from agrarians, many West Virginians in the late $19^{\text {th }}$ century had faith that development and modernization would lead to a guaranteed wealthy and prosperous future, and why not? West Virginia’s vast natural resources above and below the surface seemed to give the state an advantage

\footnotetext{
${ }^{58}$ This of course vastly simplifies the argument of the downfall of these two nations in the centuries approaching this era. George Atkinson, The ABCs of the Tariff0 (Wheeling: Daily Intelligencer, 1884), 2122

${ }^{59}$ Ibid, 5.

${ }^{60}$ Quoted in Preston County Journal, August 13, 1870.

${ }^{61}$ Parkersburg Weekly Sentinel, August 16, 1889.
} 
in creation and retention of wealth. Of course, the former was true while the latter proved false. ${ }^{62}$ It is understandable that the Intelligencer, financed by an investor in railroads and mineral extraction after 1888, would strongly support development even to the point of organizing a huge and successful economic development convention early in the year. Nationally, small town newspapers played the same role as a modern chamber of commerce. They acted as community boosters, urging development, condemning transgressions of morality, and ignoring news that might curtail development. Editorial selection meant that the papers could promote their agendas without lying or even stretching the truth. ${ }^{63}$

Many promoters of development linked industrial expansion and prosperity with the growth of railroads. ${ }^{64}$ When rail entrepreneur Elkins moved permanently to the state, Dawson, neither an outsider nor an industrialist, praised the immigration of an "enterprising" man. ${ }^{65}$ When the railroad extended to Philippi in 1884, the Philippi Republican trumpeted that "no event will ever deserve a prouder place in her history than ... the formal opening of the Grafton and Greenbrier Railroad.” It went on to state that the railroad was "taking us out of the old ruts of a dead and past civilization and [was] placing us in the grand march of progress and advancement. ${ }^{66}$ Philippi’s Republican paper definitely implied a continued disdain for Old Virginia and all its works. The development faith did not confine itself to Republican papers. Both the Charleston Daily Mail and the Democratic Charleston Daily Gazette blasted the owners of a railroad that

\footnotetext{
${ }^{62}$ Williams, West Virginia and the Captains of Industry, 2.

${ }^{63}$ Summers, Party Games, 84-85.

${ }^{64}$ Ron Eller, Miners, Millhands, and Mountaineers (Knoxville: University of Tennessee, 1982), 51.

${ }^{65}$ Preston County Journal, March, 1888.

${ }^{66}$ Philippi Republican, January 31, 1884.
} 
failed to promptly build a line to connect Charleston to Sutton. ${ }^{67}$ Some dissent did exist outside of Republican papers, and those Democratic publications strongly influenced by Standard Oil ally, Johnson Camden, and railroad magnate, Henry Gassaway Davis. The Greenbrier Independent blasted railroad extension in a series of articles that claimed, among other issues, that the Chesapeake and Ohio "carried whiskey, killed chicken and cows, scared the horses, and threw teamsters out of employment." ${ }^{\text {,68 }}$

Political corruption was a specter that haunted West Virginia politics throughout the existence of the state, but it particularly ran strong in the late 19th and early $20^{\text {th }}$ centuries. W.S. Laidley lamented the state of politics in Kanawha County, but could have spoken about most areas of the state when he wrote "Kanawha politics ... became so bad that it was feared that elections could not be held." Laidley continued, "to be a good party man, a man must go to each election with his ticket in one hand and his nose in the other." He knew where to cast the blame, though; "the people are at fault and too many are willing for a dollar or two to vote as they are paid." ${ }^{69}$ The partisan, however, generally placed the blame on the opposition. The Barbour Jeffersonian accused "Republican managers" who endeavored "to buy, if possible, enough votes in West Virginia to make it a go." ${ }^{70}$ Charleston’s Daily Gazette placed in front of its Democratic leadership the image of the corrupt Republican Hog Combine, asking "whether the county shall have government of the people, by the people, and for the people, or

\footnotetext{
${ }^{67}$ Charleston Daily Mail, September 4, 1902 and Charleston Daily Gazette, August 23, 1902.

${ }^{68}$ Ronald Lewis, Transforming the Appalachian Countryside (Chapel Hill: University of North Carolina Press, 1998), 236.

${ }^{69}$ W.S. Laidley, History of Charleston and Kanawha County and Representative Citizens (Chicago: Richmond Arnold, 1993), 152.

${ }^{70}$ Barbour Jeffersonian, August 13, 1884.
} 
government of the people, by the Hog Combine, for benefit of the Hog Combine.”71 The Daily Mail did not falter in accusations of Democratic fraud, exposing "Ring Rule in Boone: Democratic Families Again Succeed in Bagging all the County’s Nominations.”72 Some Republican leaders skillfully used the press to advance their own causes, as when Goff responded to Democrats who questioned his vote count in the election of 1888 . He stated for the New York Tribune a claim he knew would electrify West Virginia state and local publications, that Democrats crying fraud "reminds me of Satan trying to rebuke sin .. . they are steeped to the eyes in fraud." ${ }^{, 73}$ Of course, the Democratic press could not resist poking fun at Goff when the Legislature annulled his victory.

The exchange of heated rhetoric between the Democratic and Republican press helped to maintain the spirit of both sides and provided real entertainment value for the readers. The Barbour Jeffersonian stated that its rival, the Philippi Republican "would make a democrat out of most anybody. Not withstanding it pretends to great liberality, its editor, like the ticket it supports, is made up of the most relentless, remorseless, redemptionless republicans on earth.” It defended the Democratic record on prohibition and their party’s “anti-Catholic and anti-foreign born citizens’ record.”74 The Philippi Republican mined quotations from its rival that, out of context, made it look irrationally angry and ridiculous. It printed "a few specimens of high toned extracts from our esteemed contemporary, the Jeffersonian: “'test oath', 'Registration', 'He made an ass of himself as a scholar', ‘The Intelligencer's correspondent from Philippi in Tuesday’s issue is a monumental liar', What does our e.c. expect to accomplish by such choice

\footnotetext{
${ }^{71}$ Charleston Daily Gazette, September 28, 1902. Note the use of Lincoln’s phrasing. The Kanawha Hog Combine was named after a more famous organization of the same name in Ohio.

${ }^{72}$ Charleston Daily Mail, September 4,1902.

${ }^{73}$ New York Tribune, December 3, 1888.

${ }^{74}$ Barbour Jeffersonian, September 17, 1884. Entire quotation is as it was written in the original.
} 
expressions?”75 Certainly this evidences the fact that even twenty years after the Civil War ended, it remained a powerful memory in the mind of the press and the people. The Jeffersonian indeed called for "no more test oaths and registration for Barbour if you please" well over a decade after the Democrats removed such restrictions from the law. ${ }^{76}$ If a reader may have been inclined to think of the Democratic paper's statement as paranoia, its Republican rival printed earlier in the year a response to the Jeffersonian stating "somebody stir the rascals out. They've gone to hoe." It printed "the editors of the Jeffersonian are not yet so old as not to remember the days when they stirred out the hornet from his nest with a stick." ${ }^{77}$ In 1884 the Civil War was still a rhetorical conflict in Barbour County.

Attacks could take the form of name calling, such as when the Charleston Daily Gazette developed a penchant for calling W. M. O. Dawson “Slippery Bill.” The paper concluded that 'the trouble with the 'Slippery Bill' brand of harmony is that the people intended to be harmonized refuse to take the dose." It also applied the monikers "de facto Dawson” and “de jure White” to underscore a perception of the power relationship between state chair Dawson and Governor White. ${ }^{78}$ The Charleston Daily Mail enjoyed using the word "inanimate" to describe the Daily Gazette and the Democratic Party. ${ }^{79}$ Perhaps the most over the top barb was fired from the Democratic side which claimed in a rebuttal of a protectionism essay by Republican Lew Martin, "if there is anybody so stupid as the Mail it is Martin; if there is any other as inept as Martin, it is the Mail." ${ }^{80}$

\footnotetext{
${ }^{75}$ Philippi Republican, July 28, 1884.

${ }^{76}$ Barbour Jeffersonian, August 13, 1884.

${ }^{77}$ Philippi Republican, March 20, 1884.

${ }^{78}$ Charleston Daily Gazette, September 28,1902 and September 11, 1902.

${ }^{79}$ Charleston Daily Mail, September 5, 1902.

${ }^{80}$ Charleston Daily Gazette, September 4, 1902.
} 
As the $19^{\text {th }}$ century closed, many West Virginia papers did not always keep up with national trends. Across the nation the public demanded more news and less editorializing. Metropolitan papers could send writers to cover events almost anywhere, although as in the case of Hearst, Pulitzer, and others, the writers indulged the salacious at the expense of the factual. Journalists struggled to create professional standards and ethics so that the readers might trust their contributions. Editors' decision making over story selection and wording often introduced a more subtle partisanship. ${ }^{81}$ West Virginia papers could not match the resources of the big city dailies and their syndicates.

Although the West Virginia Republican press did not in many ways differ from that in other parts of the nation, it has not received a great deal of specific attention from historians. Ambler mentions the $19^{\text {th }}$ century newspapers in his textbook, but fails to cite the partisan basis of any of them, despite the fact that he does not fear discussions of politics in other spheres. ${ }^{82}$ Williams discusses how newspapers formed part of a broader scope of political mobilization in the late 1800s that also included mass meetings, printed circulars, and other devices. ${ }^{83}$ However the newspapers and their editors played a strong role in developing the state party as well as the government.

W. M. O. Dawson, George Atkinson, Albert Blakeslee White, and others were first introduced to public life through their editorship of newspapers. When Stephen Elkins wanted to finally enter state politics, he purchased a major interest in the state’s most prominent Republican paper. These men and their party recognized the power of the press, at least in certain parts of the state, to help mold public opinion. Although often the partisan newspapers stressed unity in the face of the Democratic opposition, at

\footnotetext{
${ }^{81}$ Michael McGerr, The Decline of Popular Politics (New York: Oxford, 1988),111.

${ }^{82}$ Ambler, West Virginia: The Mountain State (New York: Prentice Hall, 1940), 272-73.

${ }^{83}$ Williams, West Virginia and the Captains of Industry, 12.
} 
other times certain papers chose to participate in rebellious kicker movements or local factional spats. The partisan press was at its most enjoyable with its editors playing the role of bomb thrower against the opposition. Their sarcasm saturated style accentuated with outright insult was certainly geared to not simply inform and maintain party unity, but also to keep the readership entertained in a time before television or talk radio. Most towns of any size had papers representing each party and a few had more. However, the papers' influence in the outlying areas and among the illiterate was likely fairly marginal. Although sometimes inconsistent in its support of party leadership, it generally remained true to principles and values. Sometimes it served the politicians and others politics served the purpose of the press; most of the time it was difficult to tell where the interest of the press ended and where that of party leaders began. The one constant thread running through all of these papers was an unrelenting commitment less often to Republicans individually than to Republicanism itself. 


\section{CHAPTER FIVE}

THE ELECTION OF 1888

For Republicans, West Virginia’s gubernatorial election of 1888 began as an opportunity and ended as a fiasco, at least in the short term. Republicans tried to ride a national partisan surge on the tariff issue into power within West Virginia. Despite the serious divide opening between industrial and agrarian Democrats, Republicans gained ground but failed to reach their goals. In the long term, the ramifications of the election led to a change in leadership that took the state Republican Party to dominance in the next decade.

Goff’s leadership helped to build the Republican Party in West Virginia from the early 1870s until 1889 and his grip on patronage during most Republican administrations seemed to create security for him in that role. Patronage and a powerful public image built Goff's career and it would be the loss of patronage control that undid him in the end. This is all the more shocking in terms of his obvious popularity and abilities. The year 1888 in West Virginia saw the black voter emerge as not only a force, but also a major issue. Although many had their votes voided in 1888, Republican officials committed themselves to protecting their rights. As election results grew tighter, the necessity of garnering every vote grew in importance. The election of 1888 brought together a convergence of issues, such as the black vote and corruption, that grew in importance because of the expected closeness of the race in that year. In 1888, close state races across the country led to corruption and post-election controversies and even fighting. West Virginia's experience in this year provides a good case study. 
West Virginia’s twenty-fifth anniversary should have been an occasion to celebrate the establishment of its political tradition. The Republican Party salivated over a golden opportunity to break their opponents' sixteen year stranglehold on the governor's office as the Democratic Party's factional issues opened up publicly.. Although the Republican effort suffered from division among its leadership, whether the factions centered on agrarianism or industrialism, they tended to show stronger loyalty to overall party goals. When the governor's race ended in only a slight advantage for Goff, it resulted in an investigation that exposed some of the serious corruption that accompanied the contest, and also explored the idea of what constituted a legitimate voter. The controversy exemplified the changes taking place in West Virginia and marked a turning point in the development of the state Republican Party. Although the GOP found short term defeat, the issues raised by this contest illustrated how that organization found triumph later.

In 1888 protectionism emerged as the top national issue. After his nomination for the presidency, Republican nominee Benjamin Harrison was urged to "let the bloody shirt drop” in favor of economic issues. ${ }^{1}$ After all, an entire generation had passed since the Civil War. This indicated that Republicans had achieved another step in its maturing as a political party by dropping its early rhetoric and settling completely into contemporary issues. Republican protectionists mailed thousands of pamphlets in a campaign of education, taught parrots to mimic the free trade Democratic slogan "tariff is a tax," and spoke out against any reduction of the Hamiltonian panacea for promoting American industry. For their part, Democrats held parades where participants mocked

\footnotetext{
${ }^{1}$ Charles W. Calhoun, Conceiving a New Republic: The Republican Party and the Southern Question 1869-1900 (Lawrence: University Press of Kansas, 2006), 221.
} 
so-called "infant" industries by waving baby rattles. ${ }^{2}$ Others at this same time wondered aloud whether or not the political parties were much different at all. Looking back, one journalist wrote that "there was no choice between the two parties so far as their moral turpitude was concerned.”3 ${ }^{3}$ The electoral spirit ran high, but one expert described the differences between the parties as limited and defined by politicians and institutions. ${ }^{4}$ However, issues did divide them in economics, religion, and society. Political parties at this time remained a point of personal identification and definition for many. Goff himself emerged as a powerful promoter of the protective tariff. His advocacy for duties on coal aligned him with the interests of both miners and their employers. ${ }^{5}$ A wide variety of mining and manufacturing interests clamored for Goff's attention. Even the Wheeling Potters Protective Club implored Goff to "please exert an unusual effort to defeat the Pottery clause.”

In 1888, West Virginia anticipated the end of four years of agrarian rule in the state. Governor E. Willis Wilson, whom one historian described as "the most noted foe of corporate privilege during the Bourbon era,” led the agrarian wing. ${ }^{7}$ This faction included many of the old Copperhead and former Confederate elements who held moderate ideas on race during Reconstruction. ${ }^{8}$ His term of office ranged him among the foes of not only the Republicans, but also of powerful members of the Democratic hierarchy. Agrarians formed wings in both the Democratic and Republican Party, but

\footnotetext{
${ }^{2}$ Mark Wahlgren Summers, The Gilded Age or the Hazard of New Functions (Upper Saddle River, NJ: Prentice Hall, 1997), 212-213.

${ }^{3}$ William Allen White, Autobiography of William Allen White (New York: Macmillan, 1946),193.

${ }^{4}$ Mark Wahlgren Summers, Party Games (Chapel Hill: University of North Carolina Press, 2004),15.

${ }^{5}$ Oscar O. Frederick to Nathan Goff, January 12, 1887, Goff Papers.

${ }^{6}$ Wheeling Potters' Protective Club to Nathan Goff, March 6, 1888, Goff Papers.

${ }^{7}$ Otis Rice and Stephen Brown, West Virginia: A History (Lexington: University of Kentucky Press, 1993), 171.

${ }^{8}$ Williams, West Virginia and the Captains of Industry (Morgantown: West Virginia University Library, 1976), 9.
} 
they particularly alarmed Democratic leader Johnson Camden who had investments and other ties with the developing oil and gas industry as well as railroad construction. He also represented the "Regular" faction of the party and waged relentless political combat against "kickers."9

Agrarian kickers rejected the idea that unbridled industrial development served the best interest of West Virginia, and "regarded the railroads as the major cause of their hardship."10 They saw the combination of Camden and Davis as "monopoly and cohesive power of public plunder."11 Special tax breaks combined with poor service and high freight charges irritated the farming class almost as much as the sparks emitted from locomotives that during the dry season tended to set aflame underbrush and crops. ${ }^{12}$ The unity of West Virginia Democrats also suffered from the independent stance of

Charleston area Democratic lawyers referred to as the "Kanawha Ring.” Although every county seat could claim a political clique, law firms in Charleston with members of both parties wielded significant political strength. This particular Democratic group clustered around such figures as Senator John Kenna and future governor William MacCorkle. ${ }^{13}$

Wilson crusaded against what he perceived as discriminatory practices by railroads and also pressed for reforms that would combat voter fraud, pollution and school textbook problems, among other issues. Under the state constitution at the time Wilson could not run for reelection, although he did have senatorial ambitions. Camden and his Democratic faction blamed the kickers, who according to one local leader, "in the

\footnotetext{
${ }^{9}$ John Alexander Williams, "Davis and Elkins: Businessmen in Politics” (Ph.D. diss., Yale University, 1967), 66. Camden specifically had a powerful business relationship with John D. Rockefeller's Standard Oil Company.

${ }^{10}$ Ronald Lewis, Transforming the Appalachian Countryside: Railroads, Deforestation, and Social Change in West Virginia, 1880-1920 (Chapel Hill: University of North Carolina Press, 1998), 243.

${ }^{11}$ Williams, West Virginia and the Captains of Industry, 8.

${ }^{12}$ Ibid.

${ }^{13}$ Ibid, 10.
} 
last Legislature [were] destructive of the party organization," for the increasing rancor convulsing the party as it approached the election of $1888 .{ }^{14}$ Continuing conflict between Camden and his allies against agrarians and other factions for control of the direction of the Democratic Party convinced Republicans that their relatively unified organization had a strong chance to seize the office of governor in 1888.

Democratic struggles for party control illustrated an interesting sidebar to the year's contest: who would become West Virginia's next U. S. Senator. Although primarily an intraparty struggle due to the expected composition of that year's legislature and its constitutional role in selecting U. S. Senators, Camden feared that the "kickers" might amass enough strength to elevate Wilson to the Senate or, out of spite, perhaps even seat Goff there. ${ }^{15}$ This year seemed to be the perfect opportunity for Nathan Goff and his party to achieve some notable political success. As one correspondent wrote to Camden about Democratic dissention leading to Republican gains, "This condition of things is just what the Republicans predicted in the session of ' 87. "16

As it turned out, 1888 was a year of transition in the West Virginia party system. Henry Gassaway Davis and Johnson Camden had formed a strong, if not unassailable, alliance within the Democratic Party since the 1870s, but in 1888 they felt rather "lukewarm" about Aretus Brooks Fleming, the Democratic nominee for governor. Conversely, Davis felt a strong friendship for Goff. ${ }^{17}$ This crucial election year also saw the grand entrance of a new force in West Virginia politics. Although one historian

\footnotetext{
${ }^{14}$ Wilbur Dyer to Johnson Camden, July 31, 1888, Johnson Camden Papers, West Virginia and Regional History Collection, West Virginia University, Morgantown, WV. Hereafter cited as Camden Papers.

15 "Kickers" were generally a minor faction in a party with enough strength to cause trouble for the leadership.

${ }^{16}$ Unintelligible to Johnson Camden, November 24, 1888, Camden Papers.

${ }^{17}$ Thomas Richard Ross, Henry Gassaway Davis: An Old Fashioned Biography (Parsons: McClain, 1994), 177.
} 
derisively referred to him as “New York’s first Senator from West Virginia,” Stephen Benton Elkins had plans to move into the state political and economic system and develop a strong power base. ${ }^{18}$ Elkins, because of his success in helping to orchestrate campaigns and nominations in 1884, was called the "brains behind the Republican National Committee.” He had begun his career in New Mexico, but then moved east as he built his business and political influence. ${ }^{19}$ One coup lay in marrying the daughter of Henry Gassaway Davis, thus establishing a strong connection with the former Senator. Eventually, the partnership of Elkins and the former Democratic U.S. Senator assured the former’s political success in West Virginia.

According to some historians, to serve his own ambitions, Elkins helped to orchestrate the nomination of Goff for governor in 1888 through his partial ownership of the powerful Wheeling Intelligencer. ${ }^{20}$ Goff did not want to serve as state governor, not in 1889, not ever. His designs lay on a United States Senate seat. With the influence of the Wheeling Intelligencer and one of its new owners, the ambitious Stephen B. Elkins, the state convention selected Goff to run for that office. The constitutional change in 1872, restricted the powers of the governor. The Parkersburg Weekly Sentinel, a Democratic paper, chided, "Make Goff governor and it will break his heart. He will have to give up his palace in Clarksburg ... and during the next four years he could put in time appointing notaries.”21 Elkins saw that a Goff victory would pigeon-hole him in the office while a loss would diminish his prestige.

\footnotetext{
${ }^{18}$ John Alexander Williams, “New York's First Senator From West Virginia: How Stephen B. Elkins Found a New Political Home,” West Virginia History 21 (January 1970): 73-87.

${ }^{19}$ Mark Wahlgren Summers, Rum, Romanism, and Rebellion: The Making of the President 1884 (Chapel Hill: University of North Carolina Press, 2000), 10. Summers reference about Elkins' influence on RNC.

${ }^{20}$ John Alexander Williams, “New York’s First Senator From West Virginia”, 82.

${ }^{21}$ Parkersburg Weekly Sentinel, September 1, 1888.
} 
Demographic changes also altered the political landscape of the state. Many immigrants moved into the state during this period, accepting work in the coal fields or the timber areas, quickly altering the makeup of certain key areas. Camden had particular problems with Irish voters who felt left out of the patronage system that formed part of a "large army of the discontented."22 MacCorkle noted that as an older generation of leaders passed, the younger Democrats had difficulty because they were "not able to exercise the same power in the state in politics as their fathers did., ${ }^{, 3}$ All these factors coincided to make 1888 not only a bitter election on the surface between two political parties, but it exposed a complex kaleidoscope of shifting factions, leaders, and voting blocs. Strikingly, the diverse factions in the Republican Party converged to support Goff while the Democratic division continued to bedevil their party efforts.

A sad fact about the election of 1888 across the country was the prevalence of corruption. Scholars disagree on how great a problem it was and the nature of it, but certainly West Virginia was not immune to the allure of using money to directly influence elections. Election fraud constituted "flagrant crimes against the ballot box." It could have taken the form of false counting of ballots, multiple voting, registration fraud, ballot stuffing, violence at the polls, bribery, or employer influence. Bribery and employer influence were most often utilized, or perhaps are the easiest forms to prove. ${ }^{24}$ One study by Genevieve Gist indicated that $90 \%$ of Adams County, Ohio voters sold

\footnotetext{
${ }^{22}$ Festus P. Summers, Johnson Newlon Camden: A Study in Individualism (New York: G.P. Putnam's Sons, 1937), 295.

${ }^{23}$ MacCorkle, Recollections of Fifty Years, 435.

${ }^{24}$ Peter Argersinger "New Perspectives on Election Fraud in the Gilded Age” Political Science Quarterly 100 (Winter 1985): p 673.
} 
their choice in the 1890 s. $^{25}$ The close nature of many races meant that strategic manipulation of a relatively small number of voters could put a candidate over the top.

In 1888, one of the most overt years of election corruption, an Indiana Republican official named “Two Dollar” Dudley issued a statement infamous in the annals of political corruption. He demanded that his people "divide the floaters into blocks of five and put a trusted man with the necessary funds in charge of these five and make him responsible that none got away and that all vote our ticket..”26 Corruption used a language all its own. "Floaters" were voters not attached to a party line whether through principle or awaiting the best bid. Money used for illicit purposes was called "boodle." Democrats in Indiana praised their party's efforts in 1888, stating in one partisan newspaper that "although the Republicans had lots of 'boodle' the Democrats got a good share of the [floaters]."27 The close nature of elections and the willingness of an opponent to cheat justified illegal or unethical activities, according to historian Mark Wahlgren Summers. ${ }^{28}$ Fraud provided a strong issue that each party used to mobilize its faithful. To beat a cheating opponent, the party must work that much harder. Also each party could claim that the people really supported their platform, but had been bought off. This lessened the incentive to adjust ideologies or tactics. ${ }^{29}$

Journalist Allen Loughry cites additional factors contributing to West Virginia's

\footnotetext{
${ }^{25}$ Ibid.

${ }^{26}$ Ibid, 678.

${ }^{27}$ Ibid, 680 .

${ }^{28}$ Mark Wahlgren Summers "Party Games: The Art of Stealing Elections in the Late $19^{\text {th }}$ Century United States," Journal of American History 88 (September 2001): 424.

${ }^{29}$ Ibid 432-433.
} 
political corruption, such as poor communications over rough terrain, an undereducated population, and the possibility of violence. ${ }^{30}$ A Jackson County Democratic official stated "We have done the best we could," but then added, "our enemies are on the alert; have plenty of whiskey ... and seem to have plenty of boodle.” Republicans did not corrupt the process alone as the correspondent pointed out. “'Democrats’ want to be paid money to move and to vote their own party ticket." ${ }^{\text {31 }}$ Future Congressman Alston Gordon Dayton, who served as a local Republican campaign worker in the 1880s promised congressional candidate John W. Mason that he could help secure certain sections of Barbour County. Dayton assured Mason that "In order to fully meet the requirements we will need ... about \$75.” A hundred dollars “will be used to good effect, especially in [the Democratic stronghold of] Glade. ${ }^{32}$ The political culture of the time certainly suggested myriad ways to use $\$ 75$ - $\$ 100$ to good effect.

Despite his public statements about not desiring the prize, Goff received the Republican nomination for governor on August 22, 1888, on the first ballot at the state convention in Charleston. A Goff biographer credits the emphatic move as a sign of Republican unity and Goff did bring the spirit of the righteous underdog to the fight: "It is the world against the United States and I am for the United States. It is the world against West Virginia, and I am for West Virginia.” Goff notably added, “We appeal to the understanding and reason, not to ignorance and prejudice.,33

\footnotetext{
${ }^{30}$ Allen Loughry, Don't Buy Another Vote, I Won't Pay For A Landslide: the Sordid and Continuing History of Political Corruption in West Virgina (Parsons WV: McClain Printing, 2006), 91.

${ }^{31}$ Unknown to Johnson Camden, November 3, 1888, Camden Papers.

${ }^{32}$ Dayton to Mason, September 23, 1882, Mason Papers.

${ }^{33}$ Smith, Nathan Goff Jr. A Biography, 159. This is a common theme in West Virginia Republican contests due to the fact that they generally over the years have been outmanned and outgunned by their opponents.
} 
One of the most important voting groups in the election of 1888, especially for the Republican Party, was the black community. Since the Civil War, West Virginia had shown some unease at times over black political participation. Some opposed statehood if it meant emancipation, apparently unaware that the Civil War itself could mean emancipation. By 1870 many Republicans felt uneasy about white former Confederates blocked from citizenship while blacks gained the right to vote. Even some of those who supported black citizenship rights had difficulty arguing that whites should continue to be disabled while blacks gained full access. The debate between the "let ups" and the Radicals disintegrated the old party. Meanwhile blacks struggled to find their place in the political system of West Virginia. The Constitution of 1872 mandated segregated schools and laws mandated a minimum number of students before a new school could open. On the other hand, Republican Booker T. Washington helped mobilize voter support for the relocation of the state capital to Charleston. ${ }^{34}$

Blacks found themselves represented both as evil geniuses and buffoons in various parts of the South. In Charleston, South Carolina the nomination of a black Republican to a judgeship inspired the headline CIVILIZATION IN PERIL. Hysteria swept through some parts of the South where blacks had a high minority or a majority of the population. These would be usurpers who, according to some people, tried to create "an African dominion," also found themselves ridiculed at every turn. Black legislators in parts of the South saw their speeches rendered to the public in almost impenetrable dialect and malapropisms. They found themselves described as the pawns of northern Republicans. Although they did defer to whites most of the time, they had an

\footnotetext{
${ }^{34}$ Joe William Trotter, Coal, Class, and Color: Blacks in Southern West Virginia 1915-32 (Chicago: University of Illinois Press, 1990), 29, 47.
} 
appreciation of their potential power in places where the black population remained high. $^{35}$

Southern states opposed the $14^{\text {th }}$ and $15^{\text {th }}$ Amendments which granted blacks full citizenship rights. Southerners determined to prevent black citizens from gaining power demonstrated an inability to appreciate the value and principles of "representative democracy," according to a contemporary European observer. To justify their position, he wrote, they had to show that blacks as a group were not "capable of worthily maintaining and bravely defending a democratic constitution, which demands a rare self-control and manly energy. ${ }^{, 36}$ West Virginia was considered southern by many in the $19^{\text {th }}$ century despite its rejection of that section during the war. ${ }^{37}$ The state's Republicans shared with Dixie-based party organizations the necessity of recruiting blacks to vote in large numbers for its candidates. One historian commented that the Southern question was not just important, but "central . . . to the party’s sense of itself and its mission.”38

West Virginia Republicans faced charges of black “colonization,” relating to the "illegal" importations of voters into certain counties to bolster GOP results. ${ }^{39}$ Most of the accused border crossers hailed from Virginia and worked for coal or other extractive industries in West Virginia counties. Some companies specifically advertised better conditions in West Virginia, creating a "pull” factor that brought in blacks for reasons

\footnotetext{
${ }^{35}$ Thomas Holt, Black Over White: Negro Political Leadership in South Carolina During Reconstruction (Bloomington: University of Illinois Press, 1979), 95-96.

${ }^{36}$ J. K. Bluntschli, The Theory of the State (Oxford: The Clarendon Press, 1892), 179.

${ }^{37}$ Used footnote from New York Times earlier to demonstrate this. West Virginia dispatches lumped into section titled "The South."

${ }^{38}$ Charles W. Calhoun, Conceiving a New Republic: The Republican Party and the Southern Question 1869-1900 (Lawrence: University of Kansas Press, 2006), 1.

${ }^{39}$ J.H. Jacobs, “The West Virginia Gubernatorial Election Contest 1888-1890,” West Virginia History 7 (April and July 1946):179.
} 
other than simply perpetuation of voting. ${ }^{40}$ However, some West Virginia blacks had grown disenchanted with the Republican Party by 1888. They felt that the GOP offered them just enough to ensure support while emphasizing "white” issues. ${ }^{41}$ Despite its relatively quick demise, the establishment of a Colored Independent Party loosely allied with Democrats showed that at least some black leaders had ceased to trust Republicans on issues they considered paramount. Blacks had shown strong support for Goff personally, as in 1882 when conventions declared Goff "the unanimous choice of the colored people of the first district for Congress." ${ }^{42}$ Thus, West Virginia black voters held in 1888 a potential key to victory.

The situation of Virginia blacks was more challenging. The post Reconstruction Virginia conservative Redeemers, made a concerted effort to regain control of their Commonwealth. This meant subverting the tenuous alliance among Republicans, poor whites and blacks and somehow defeating their leader, former Confederate General William Mahone. Republicans in Lynchburg as well as poor blacks not far from the West Virginia border complained of persecution by authorities and vigilance societies. ${ }^{43}$ By 1883, the resurgent conservatives had seized a majority in the Virginia General Assembly, causing the Democratic press to crow that "the good name of Virginia has been redeemed.”44 Their first salvo against Republicans and blacks took the form of the Anderson-McCormick Election Act of 1884. It undermined Republicans’ ability to win

\footnotetext{
${ }^{40}$ Kenneth R. Bailey, “A Judicious Mixture: Negroes and Immigrants in the West Virginia Mines 18801917,” West Virginia History 34 (January 1973): 156.

${ }^{41}$ McKinney, “Southern Mountain Republicans and the Negro 1865-1900,” Journal of Southern History 41 (November 1975): 494.

42 Davis, The Speeches of Nathan Goff Jr., 67.

${ }^{43}$ Steven Elliot Tripp, Yankee Town-Southern City: Race and Class Politics in Civil War Lynchburg (New York: New York University Press, 1997), 200-201.

${ }^{44}$ Raymond H. Pulley, Old Virginia Restored: An Interpretation of the Progressive Impulse 1870-1930 (Charlottesville: University of Virginia Press, 1968), 44.
} 
elections by placing appointments to local election boards under direct control of the Democratic legislature. $^{45}$

The issue of migratory lifestyles played a major role when the West Virginia Legislature's Joint Commission met several months after the election of 1888 to discern legal from illegal votes in the governor's race. Black and poor white workers were much more migratory than their middle and upper class counterparts. State boundaries meant little to those who made their living in the mines or the forests because laborers found irregular work on both sides of the Virginia-West Virginia line. Workers might move when their job was over or to search for higher wages; as the majority of commission members appointed to recount the votes of the 1888 election decided, these blacks were nomadic in that they were "coming and going all the time" and that they had no intent of accepting permanent employment or staying in West Virginia to establish permanent residence. They cited payroll records that showed lack of continual work over a several month period as proof. ${ }^{46}$ The minority on the commission contended that irregular work did not necessarily negate status of residence and that the laborers could have just as easily migrated from within the state. ${ }^{47}$ Black voters and their employers suffered accusations of abetting the Republicans in election fraud. Almost certainly both the Democrats and Republicans had sullied their hands with election fraud in these nineteenth century elections. The commission eventually found that the black voters had cast their ballots by mistake rather than by purposeful fraud. It did them little good to

\footnotetext{
${ }^{45}$ Ibid, 45. Pulley claims that "it is clear that the Democratic triumph in 1883 was achieved through wholesale fraud at the polls. A Rockingham County Republican who slightly won the popular vote lamented "I have no doubt the Bourbon canvassing board will count us out on a mere technicality ... The funders used about $\$ 3,000$ purchasing every possible vote using whiskey (and) every means of fraud."

${ }^{46}$ James Henry Jacobs, "West Virginia Gubernatorial Election Contest 1888-1890," West Virginia History 2 (April 1946): 290.

${ }^{47}$ Ibid.
} 
attend the polls in the Old Dominion. Possibly the knowledge that their votes counted in West Virginia drew them there.

Redeemers conquered the political systems of most Southern states as Reconstruction faded. They changed voting regulations almost yearly, gerrymandered blacks into single districts or diluted their voting strength among several to reduce the number of Republican congressional representatives. All the time they bashed the Republican Party as one of black advancement at the expense of whites. For their own purposes, some Republican organizations turned away from civil rights towards issues of development throughout the South. Protectionism and public education replaced a previous generation's call for human dignity. Every so often a Republican might sway Democrats on these issues, but in reality "Redeemers owned the South, lock, stock, and ballot box." ${ }^{48}$ In South Carolina, for example, Republican rule collapsed "like a rope of sand” in 1877 when Democrats gained majorities and Reconstruction ended. Ruthless investigation tactics of Reconstruction era corruption led some of the remaining Republicans to resign in protest, others abandoned politics out of fear. Governor Wade Hampton's moderation towards white Republicans co-opted more of that party and the black majority lost its political influence there as well. ${ }^{49}$ In comparison to West Virginia, opportunities for political expression in the South grew very bleak for blacks in the decade prior to the election of 1888 and only continued to worsen. Consequently, it would not take much "boodle" or other forms of prodding to convince them to vote for Goff and other Republicans.

National issues, especially the protective tariff, dominated the 1888 gubernatorial

\footnotetext{
${ }^{48}$ Summers, The Gilded Age, 37-38.

${ }^{49}$ Thomas Holt, Black Over White: Negro Political Leadership in South Carolina During Reconstruction (Chicago: University of Illinois Press, 1977), 210-211.
} 
election in West Virginia. Goff stood with his party, backing the tariff and mixing some occasional traditional Anglophobia into his statements. When commenting upon Democratic support of free trade, he said "It looks to me as if the Democratic Party has been caught again in bad company. They are coquetting again with our enemies across the sea." ${ }^{\Perp 0}$ The partisan press also cited Great Britain as a source of nefarious machinations with the Democrats. The Kingwood New Era proclaimed that workers fled for the United States because of the protection given by the tariff, and blamed Democratic free trade leanings upon British influence. ${ }^{51}$ Except for some indirect effect upon the senatorial election, a West Virginia governor would exercise almost no influence on the tariff issue although Goff stated that a person should have knowledge of the subject "if he is a fit person to fill the office of Governor." Aretus Brooks Fleming, the Democratic nominee, spent more time addressing concrete state issues from the judicial bench than ruminating over national tariff policy. This did not mean that the Democrats did not weigh in on the issue. As mentioned previously, the Parkersburg's Weekly Sentinel satirically requested reproduction of a "ponderous" editorial on the potato tariff from its Republican rival. ${ }^{52}$

State Republicans sensed weakness and were determined to draw Fleming into a debate on the tariff. Fleming's advocates admitted the candidate's lack of experience on the issue and parried by offering Congressman William Wilson of the second district and the House Ways and Means Committee, as an alternative.

Democratic chairman T.S. Riley argued that Fleming's isolation "from all active politics

\footnotetext{
50 Address to Philadelphia Young Republicans, Goff Papers.

51 New Era (Kingwood, W.V.), November 2, 1888.

${ }^{52}$ Parkersburg Weekly Sentinel, August 16, 1889.
} 
and political discussions” placed him at a severe disadvantage. ${ }^{53}$ Although Republican Executive Committee Chairman W. J. W. Cowden insisted "there is no obligation on your part to meet Mr. Wilson,” Goff took up the challenge and agreed to a series of debates. $^{54}$ They took place in Martinsburg, Wheeling, Montgomery, and Parkersburg in front of huge crowds. Neither man lacked humor or emotional appeal, and both parried questions cleverly. Wilson argued that the tariff equaled a tax on consumers and only benefited manufacturers, while Goff reiterated his belief that it protected workers from foreign, especially British, competition. Both sides tried to paint their positions as beneficial to the American worker, targeting the growing industrial labor class as well as their bosses. ${ }^{55}$ It is difficult to tell whether these debates made much impact on the election, but they did give William Wilson a statewide forum and may have boosted his political visibility.

In contrast to the eloquent and vociferous Goff, Fleming had a reputation as a quiet judge. ${ }^{56}$ He lacked the experience of connecting with a crowd that Goff had spent years perfecting. A rural state campaign in those days was rather similar to those a hundred years later; candidates held barbeques, gave emotional speeches, invited national figures, marched in parades, and, in general, tried to present an image of triumph, celebration, victory, and fun. Differences then or now lay in the occasional presence of liquor and of the "unnatural, scathing, sordid" tone of highly charged newspaper editorials. ${ }^{57}$ Fleming had some important political assets. In particular, he had business connections with Camden and his supporters in the upper Monongalia coal fields. This

\footnotetext{
${ }^{53}$ T.S. Riley to W.J.W. Camden, September 12, 1888, Goff Papers.

${ }^{54}$ W.J.W. Cowden to Nathan Goff, September 12, 1888, Goff Papers

${ }^{55}$ Smith, Nathan Goff Jr., A Biography, 161-162.

${ }^{56}$ Jacobs, “The West Virginia Gubernatorial Election”, 170.

${ }^{57}$ Ibid, 171.
} 
network of friends balanced in some ways his deficiencies in public political campaigning. $^{58}$

As Election Day passed, complaints about fraud and irregularities increased. Theodore Lang of Baltimore warned his friend Goff about the common perception of southern state governments in that period, that the "Bourbons [will] fix up the returns.",59 William McCorkle alleged fraud before the votes had even been counted. ${ }^{60}$ Allegations commonly centered on distribution of “boodle,” or money paid for each vote. One Ravenswood resident complained to Johnson Camden, "We have all done the best we could and hope to carry this county; but our enemies are on the alert; have plenty of whiskey and been distributed all over the county and seem to have plenty of 'boodle., 61 Local Republicans in southern West Virginia alleged that U. S. Senator "Kenna has had his henchmen in both counties . . . but it will avail nothing.” They also claimed that Democrats sent $\$ 1,000$ to Wyoming County and $\$ 500$ to McDowell to influence voters. ${ }^{62}$ Election fraud could also come from corrupt local election officials. For instance, Joseph Barry of Martinsburg wrote "shameless partiality [was] exhibited on election day here by the Democratic Judges.”63 Hardy County Delegate Joseph Sprigg tried to alert Johnson Camden to fraud in his area. Sprigg maintained, “if, however, one half we hear be true, he [Goff] should not be allowed to take his office without a contest." ${ }^{64}$ A Jackson County resident also complained to Camden, “The most discouraging feature of

\footnotetext{
${ }^{58}$ Summers, Johnson Newlon Camden: A Study in Individualism (New York: Putnam, 1937), 421.

${ }^{59}$ Theodore F. Lang to Nathan Goff, October 12, 1888, Goff Papers.

${ }^{60}$ Jacobs, "The West Virginia Gubernatorial Contest “, 180.

${ }^{61}$ E.W. Unintelligible to Johnson Camden November 3, 1888, Camden Papers

62 J.G. Walls to Goff, December 14, 1888, Goff Papers. John Kenna was a Kanawha County Democrat and Camden ally eventually chosen to represent West Virginia in the United States Senate.

${ }^{63}$ Ibid, Joseph Barry to Nathan Goff, December 21, 1888, Goff Papers. Barry was President of the Goff Republican Club in Harpers Ferry.

64 Joseph Sprigg to Johnson Camden, November 22, 1888, Camden Papers
} 
this campaign to us has been the discreditable fact that so many Democrats want to be paid money to move and to vote their own party ticket." 65 The most remarkable accusation came from Logan County where a Republican partisan claimed that Democratic voters were "taken to a House of ill fame and the tickets was [sic] handled by women of ill-fame."66 Even more perplexing came the accusations from Preston County where rival Republican publications accused each other of fraud, especially in the case of “kickers” who perhaps illegally created false ballots in blue ink. The Preston County Journal denied the charges and insisted that, regardless of ink color, ballots in a box cannot be discounted. $^{67}$

In the nineteenth century, election returns took time to count and assemble so even election day, supporters of both sides maintained shrill tones in the partisan press. Some combined victory celebrations with warnings of scheming; one headline read, “Goff Elected And He Will Take His Seat or Know the Reason Why.” It was followed by one reading “The Democratic Determination to Cheat the People Through Manipulation of Returns-Democracy’s Last Desperate Kick.”68 These mid-November headlines anticipated the result of the canvas by nine days as Goff waited until November 20 to proclaim victory.

Democrats reeled from the apparent November defeat, one that initially seemed to complete the rending of the party. An eastern panhandle editor blasted Johnson Camden by writing, “The virtual defeat of our party in the gubernatorial contest is humiliating enough.” Worse, "when we reflect that it has been brought about by the

\footnotetext{
${ }^{65}$ E.W. Unintelligible to Johnson Camden, November 3, 1888, Camden Papers.

${ }^{66}$ Harvey Loving to Nathan Goff, December 18, 1888, Goff Papers.

${ }^{67}$ Preston County Journal (Kingwood, W.V.), November 1, 1888.

${ }^{68}$ New Era (Kingwood, W.V.), November 16, 1888.
} 
gross incompetency and unprincipled selfishness of our would be leaders ... the situation becomes almost intolerable." ${ }^{\prime 69}$ These recriminations came two weeks after the West Virginia Democrat confidently predicted that "the next time the Honorable Nathan Goff runs for Governor, it will be upon some other hobby than a War Tariff.,70

Camden had prepared a strong response through the Parkersburg Weekly Sentinel. As November ended, the paper appeared to try and establish a high moral tone for the continuing controversy when the editor wrote, "We have no fault to find with the efforts of candidates to be elected ... we do object to the ceaseless cry of fraud that is sent out as an excuse for the defeat.” The Weekly Sentinel purported to fear how the accusations would affect the state's already tarnished political reputation. Despite the supposed victory, Republicans proved as eager as Democrats to report fraud to their party leaders. James Butt of Harpers Ferry wrote Goff in late November that "In addition to rejecting a large bunch of legal Republican voters, [Democrats] admitted a large number of illegal voters from Maryland and the District of Columbia." ${ }^{, 71}$ At the same time as they advocated honest efforts to find the truth without calls for fraud, the Weekly Sentinel taunted Goff who, even if victorious, still would have to work with a Legislature with a majority of Democrats. "We hope some way will be found to give Goff the governorship," it proclaimed "Make Goff governor and it will break his heart. He will have to give up his palace in Clarksburg ... and during the next four years he could put

\footnotetext{
${ }^{69}$ West Virginia Democrat (Charles Town, W.V.), November 16, 1888.

${ }^{70}$ Ibid, November 2, 1888.

${ }^{71}$ James Butt to Nathan Goff, November 22, 1888, Goff Papers. Butt was a Harpers Ferry attorney.
} 
in his time appointing notaries." Elsewhere it said, "Make him governor and bury him.,"72

Despite this "support” for Goff's claims, the next week brought the first of two strong responses by the Democratic leadership. First, the Democratic nominee, Judge Fleming,sounded a strong and defiant tone, "General Goff proceeds to claim without any qualification whatever that 'we have carried the state'” despite incomplete and disputed returns. Fleming then went on the attack, "This does not appear to me to be the attitude or the language or the spirit of a candidate who sincerely desires to arrive at the truth.,73 Of course, Goff chose the correct course politically by proclaiming himself the victor on the apparent face of the returns, and any politician could appreciate that. Fleming's letter seems more a piece of political calculation than outrage. Its close appealed, as usual with both candidates, on behalf of "the rights of the people" with Fleming's declaration that "I do not intend to be bulldozed into a concession., ${ }^{74}$

The next Democratic response to Goff took full form in a "manifesto" issued by Camden and the Democratic executive committee a week after Fleming’s statement. Democrats went on the offensive with a powerful slate of accusations against Republican campaign efforts. First, they alleged that the "Solid South" was to be "broken" by the purchase, as they put it, of West Virginia. ${ }^{75}$ It was no secret that the Republican national

\footnotetext{
${ }^{72}$ Parkersburg Weekly Sentinel, November 24, 1888. The Democratic "majority” was not quite what the editor made it out to be. With a majority of one party member in one house and a considerable "kicker" element that Camden repeatedly tried to purge from party decision-making, a skillful governor could exploit the situation to his advantage.

${ }_{73}^{73}$ Ibid, December 1, 1888.

${ }^{74}$ Ibid.

${ }^{75}$ Ibid, December 8, 1888.
} 
leadership, headed by Matthew Quay, wanted to expand its electoral base and saw Goff's candidacy as "a bold dash to break the Solid South.,"76

Tangible patronage support from elected officials diminished for Goff due to his support of James G. Blaine’s presidential aspirations, but Quay saw the former general as the Republicans' best chance in the South. Goff himself declared that his victory meant that West Virginia had at least cracked that concept. ${ }^{77}$ Despite the Weekly Sentinel's request that accusations of fraud cease, it obligingly printed a list of alleged unsavory practices. Republicans had supposedly "boldly advertised" schemes of black colonization, sent "paid agents” to ransack "every hamlet” looking for the "needy and distressed." According to the Democratic manifesto, "the Republican speaker and the Republican writer abdicated their functions in favor of the Republican boodler.” Then, the committee presented the following "facts" that repeated, in part, earlier allegations. Men were hired to work for the Republican Party, a practice the Democrats referred to as “criminal bribery," voted for the Republican ticket in counties where they had no right to vote, voted repeatedly, and encouraged non-residents to participate. Additionally, Republicans were accused of inducing minors, paupers, and imbeciles to go to the polls. The combination of these amounted to a "widespread conspiracy to debauch the ballot of this state., ${ }^{, 78}$ Although this represented the official Democratic position on the election, the West Virginia Democrat a week earlier offered other reasons for the poor showing of the party. It blamed Congressional representatives who misused patronage (according to the rules of the day, this meant using it to bolster yourself and not your party), a state

\footnotetext{
${ }^{76}$ Smith, Nathan Goff Jr. A Biography, 159.

${ }^{77}$ New York Times, December 5, 1888.

${ }^{78}$ Parkersburg Weekly Sentinel, December 8, 1888. The article was titled "Democratic Committee Issues a Manifesto.”
} 
convention packed against kickers, and the use of party machinery to "suppress the public will."79

Goff and many Republicans remained focused on the governor’s mansion. Republican correspondence reflects a concern with the reassessment of returns, particularly in Mercer, McDowell, and Wyoming Counties where George Thompson, editor of the Southwestern Protectionist, worried that affairs were "not in good shape" due to the failure of an official to promptly draw a counternotice of contest locally. ${ }^{80}$ Although a slim opportunity existed for Goff to be chosen U. S. Senator in the upcoming session, the focus rested on the governor's race, based upon his statements reported in the New York Tribune. In the Tribune, Goff had attacked his opponents, claiming that Democrats crying fraud "reminds me of Satan trying to rebuke sin” for "they are steeped to the eyes in fraud.” He promised that some would end up incarcerated as a result of their crimes, "Democrats assert that whenever a county which gave a Democratic majority four years ago gave a Republican majority this year there is prima-facie evidence of fraud.”81 Goff also remained in consideration for a cabinet post in the new Republican administration of Benjamin Harrison, backed enthusiastically by the president-elect’s son. However, Goff “absolutely withdrew” himself from consideration and endorsed Stephen B. Elkins instead. ${ }^{82}$

As 1888 ended and 1889 began, Goff ended speculation that he would accept another role, either in the President's Cabinet or in the US Senate, stating “I would no more compromise this issue than I would pick a pocket ... You are authorized to say ...

\footnotetext{
${ }^{79}$ West Virginia Democrat, November 30, 1888.

${ }^{80}$ George Thompson to Nathan Goff, December 27, 1888, Goff Papers.

${ }^{81}$ New York Tribune, December 3, 1888.

${ }^{82}$ Smith, Nathan Goff Jr., A Biography, 171.
} 
that I am going to be the next Governor of West Virginia." ${ }^{83}$ The legislature met in Charleston on January 9 with Democrats enjoying a thirty-two to thirty edge in the House of Delegates with three Union-Labor members, only one of whom had any affiliation with the Republicans. ${ }^{84}$ This combination foretold which way the House of Delegates would lean when the third party joined Democrats to elect a Speaker representing their party. The Senate was divided between twelve Democrats, thirteen Republicans, and one Union-Labor, R.S. Carr. Although Carr had originally received a Republican endorsement, clearly judging by the tone of his correspondence with Camden he now leaned in the Democratic leader's favor. Goff's supporters tempered their hopes with pessimism, B. F. Martin Jr. wrote, "There is every reason to believe that the Democratic Party will do its utmost before the legislature to cheat you of the position to which you have been honestly and fairly elected.”85 Democratic control of the legislature certainly signaled a blow to the hopes of Goff winning the governor's office.

Initially, the battle centered on what to do with the returns that seemed to show Goff the winner. Read into the Legislative record, it represented a victory, if only psychological and for public relations purposes, for Goff. Republicans wanted all of the county results delivered by Secretary of State Henry Walker to the speaker of the House of Delegates, but Walker could not deliver Kanawha County returns because of a court injunction. Results of the fifty-four counties outside of Kanawha delivered a clear plurality for Fleming. The real measure of victory lay in convincing the speaker of the House of Delegates to open the returns which should have been done "immediately after

\footnotetext{
${ }^{83}$ Smith, Nathan Goff Jr., 173.

${ }^{84}$ The Union-Labor Party was a national organization that combined some Marxist thought with traditional American populism against what it saw as the overwhelming power of business.

${ }^{85}$ B.F. Martin Jr. to Nathan Goff, December 26, 1888, Goff Papers.
} 
organization of the House and before proceeding to business.” Then, according to the state constitution, both houses of the legislature should have been summoned to hear the results. In the case of a tie, the legislature would have the power to appoint the next governor from among the candidates involved ${ }^{86}$ In this case no one had asserted a tie had taken place, and the election fell through a crack in the law. The problem lay in the fact that returns in some areas had been jumbled and disputed. The election process, even in modern times, runs increasingly into gray areas the closer the vote count gets; in the absence of clear precedents, statutes and methods, confusion increases. When this occurs, courts, legislatures, and candidates all engage in battles that help set precedents and dictate how future generations might handle similar situations.

The joint assembly convened on February 1 to decide how to resolve the voting issues in the gubernatorial contest, not to record the results. Democratic legislators relied upon the constitutional clause concerning disputed elections to fashion an implied power to investigate and determine the results of the returns before they read the final results into the record and declared a winner. Goff's proposition that the legislature declare him governor first and then investigate the returns failed to resonate with the Democratic majority. He warned that "I will not yield one jot of their [voters'] rights and my lawful title. ${ }^{\text {„87 }}$ Persistent dissention in the Democratic ranks kept Republican hopes alive, despite the fact that Democrats controlled the process. One example was the January Democratic caucus machinations on the U. S. Senate race. Some kickers had failed to support a return of Camden ally, John Kenna, to the Senate. Although Kenna eventually triumphed over Goff, nominated by Republicans as a courtesy, the dissatisfaction of the

\footnotetext{
${ }^{86}$ Darrell E. Holmes ed., West Virginia Blue Book, 2006 (Charleston WV: Chapman Printing, 2006), 392.

${ }^{87}$ Wheeling Intelligencer, January 1, 1889.
} 
Democrats and third party legislators opposed to Camden helped to maintain Republican chances in the governor's race. Republicans could hope that Camden hatred among kickers might convince some Democrats to support Goff, just to spite their party leader. While Goff supporters glossed over the inability of Republicans to elevate him to the Senate, it was clearly a hard fought loss. Republican Party chair and Goff ally W. J. W. Cowden observed a few weeks later that "our failure to elect Goff to the Senate was a great disappointment. The party lines were more clearly drawn and the personal bitterness intense.”88 Drawing upon these Democratic divisions would continue to produce increasing optimism for Republicans until their 1896 takeover.

Finally, the joint assembly decided to open and record all results for the statewide elections with the exception of the gubernatorial race. "Gen. Goff's fate as Governor of West Virginia was sealed today. It was obvious the joint assembly would never declare him elected ... his little majority will be swept away by the conclusive logic of a bare majority in the Legislature," mourned the Wheeling Intelligencer. ${ }^{89}$ The Kingwood New Era sadly stated, “The deed is done and the Democrats have decided the Constitution doesn't count." ${ }^{90}$ A bare legislative majority was reflected in the joint committee selected to decide on the legitimacy of the contested votes; three House Democrats joined two senate Republicans.

February ended with damaging revelations that would recur throughout the process. Democratic Delegate A.B. Shelton of Lincoln County claimed that a Hamlin Republican, A.S. Ray, had offered him $\$ 1600$ to leave the state and avoid sitting in the

\footnotetext{
${ }^{88}$ W. J. W. Cowden to Matthew Quay, February 27, 1889, Department of Justice Records, Record Group 60.

${ }^{89}$ Smith, Nathan Goff" 180.

${ }^{90}$ New Era (Kingwood, W.V.), February 8, 1889.
} 
Legislature and that another offered $\$ 1000$ to vote for Goff in the senate election.

Legislative investigators substantiated the first charge and dismissed the second. Ray accused a Huntington Republican, who had long since escaped to Kentucky, of facilitating the attempted bribe. Without mentioning Goff specifically, Democrats now had ammunition that implied Republicans’ willingness to corrupt even the state legislature to put their nominee into office. March 4, the constitutional inauguration date, approached and signaled a day of decision for the contenders.

In March, the gubernatorial contest took a turn for the absurd. Goff announced his intention to take office, setting Democrats in the Capital city to fright. Rumors swirled through Charleston that the former Union officer had pulled together an army to force a coup. Indeed, the Wheeling Intelligencer advocated that he "call to his aid the military of the state." ${ }^{\prime 1}$ A century and some decades later these fears may seem almost ludicrous. However, in Arkansas rival groups smashed newspaper presses, intimidated reporters, burned businesses, and counted out votes. Both political parties mobilized armed militias. Texas, Florida, and Alabama all experienced the creation of rival state governments after bitterly disputed elections marked by accusations of fraud. ${ }^{92}$ This did not happen in Charleston. Instead, Goff simply appeared outside the State Capitol with his supporters, gave a short speech, and declared himself the Governor of West Virginia. ${ }^{93}$ Wilson responded with a declaration that, since the state declared no winner and no one else was legally able to take office, he would continue until the problem was resolved. Goff replied to Wilson that the election returns themselves signified he won. The Republican claimant's assertion that he did not need the legislature's affirmation

\footnotetext{
${ }^{91}$ Wheeling Intelligencer, March 4, 1889.

${ }^{92}$ Mark Wahlgren Summers, Party Games,12, 428.

${ }_{93}$ Jacobs, “West Virginia Gubernatorial Contest”, 263.
} 
impressed no one. Not long after Goff claimed the office, State Senate President Robert S. Carr claimed the office himself. Carr interpreted the state constitution to read that since the office of governor had not been legally filled, it fell to the next man in succession.

Goff looked to the courts for relief. His lawyers applied for a writ of mandamus from the West Virginia Supreme Court of Appeals to direct Governor Wilson to turn over the instruments of the office to Goff, and, in essence, declare him governor. The petition specifically requested that Governor Wilson "show cause why he should not be compelled to surrender to petitioner said office." ${ }^{94}$ In Goff v. Wilson, Goff argued that the governor's term by law ended on March 4 but that Wilson refused to surrender to office "and still holds and detains the said office, property, and insignia against the right and demand of petitioner and declares that he will continue to do so." ${ }^{\text {95 }}$ The Republican candidate insisted that, on the face of the returns, he ought to be governor and that the failure of the legislature to open and record the returns constituted no barrier to Goff's rightful possession of the office. Goff was asking the court to ignore Article VII Clause 3 that necessitated the legislature's sanction of the election results. ${ }^{96}$

The court refused to follow Goff's lead. ${ }^{97}$ It supported the legislature’s decision to defer a decision, stating that the result of prematurely approving a governor in such unsettled conditions "might be to place in the high and responsible office of governor ... a person who had never been elected.” The Court cited a circuit court injunction against

\footnotetext{
${ }^{94}$ Goff v. Wilson, Supreme Court of Appeals of West Virginia, Charleston, 32 W.Va. 93; 9 S.E. 26; 1889 W.Va. Lexis 87.

${ }^{95}$ Ibid.

${ }^{96}$ Darrell E. Holmes, ed., West Virginia Blue Book 2005, (Charleston, WV: Chapman Printing, 2005), 551.

${ }^{97}$ The West Virginia State Supreme Court of Appeals in 1889 was composed of Adam Snyder of Greenbrier County, John English of Mason County, and Henry Brannon of Lewis County. All were Democrats at the time, but Brannon switched parties later in his career.
} 
the opening of the Kanawha County results as an example later in the opinion. Justices went on to call a claimant that prematurely took office potentially a "mere intruder because he had never been elected and was never legally entitled to the office." State constitution framers placed determination of elections in the hands of the legislature, and according to the court, that was where the decision would lay. ${ }^{98}$

Nineteenth century courts tended to avoid ruling in cases that could be construed as more political than judicial. Preferably, these issues were sent to the legislative branch; when the West Virginia Supreme Court did so, they simply followed the conventions of the times. In denying the writ of mandamus and dismissing the petition, the Court delivered a sharp blow to Goff's hopes. It rejected his assertion that the legislature should place him in the office for the time being until the vote count could be established. The Wheeling Intelligencer blasted the Court, reasoning that it "commanded the Speaker of the House not to perform his constitutional duty." It continued, "Mr. Wilson and the Democratic Party are to profit by the Democratic Party's violation of the Constitution." ${ }^{\text {999 }}$ This sounded the death knell of Goff's chances. As John Alexander Williams has stated, "with Democratic control of the state courts and militia, there was little Goff's supporters could do short of violence except wait out the Democratic maneuvers in the almost certain knowledge that he would be counted out."100

The Joint Contest Committee to review the disputed votes met first in Charleston in April, 1889. It met not to declare a winner, but to investigate each disputed vote. Although Williams referred to the process as "further discreditable proceedings," the

\footnotetext{
${ }^{98}$ Ibid.

${ }^{99}$ Wheeling Intelligencer, March 13, 1889.

${ }^{100}$ John Alexander Williams, "Davis and Elkins of West Virginia: Businessmen in Politics” (PhD

Dissertation, Yale University, 1967), 148.
} 
excessive length of the investigation at least provided the façade of thoroughness, if, in fact, the proceedings were inevitably a fait accompli for the Fleming camp. ${ }^{101}$ The Committee looked at several areas to determine the legitimacy of a vote. First was the problem of polling places established in areas not specified in the law; they decided early that this did not disqualify the votes cast there. It was not seen as a denial of the right to vote or an intentional fraud. ${ }^{102}$ The Committee took most of its time examining the residency qualification using company payrolls and the testimony of witnesses as evidence. To be considered a legal resident, one must have lived in the county for sixty days or in the state for one year. Definition of residence was established as making a home in a given place for the requisite amount of time. Voters were disqualified based upon the idea that migrant work habits precluded the establishment of a permanent residence. The committee also rejected votes from those who lived permanently in one county, but voted in their county of employment. By this point in his allegations, Fleming dropped the inflammatory rhetoric about Republican fraud advanced in December; his charges now centered upon improper votes. ${ }^{103}$

With a Democratic majority on the Joint Contest Committee, the result was inevitable. As the group moved from Charleston to Grafton to Terra Alta to escape the sweltering summer heat and the scrutiny of the candidates, the state moved on to other business. ${ }^{104}$ By fall it had become reasonably clear that the committee would declare Fleming the winner, which it finally did in December of 1889. In January, 1890, the legislature made it official and Wilson stepped aside for Fleming to serve an

\footnotetext{
101 Ibid, 149.

102 Jacobs, “The West Virginia Gubernatorial”, 275.

103 Ibid, 282-289.

104 There is no need to repeat a blow by blow account of the summer proceedings as they have been thoroughly covered already by Jacobs and Smith.
} 
abbreviated term. Some press outlets heaped criticism on Goff. The New York Times concluded that "the obstinate contest which the Democrats of West Virginia made a year ago ... seems to be fully justified by the result of the investigation.” It was called an "outrageous fraud" that blacks had been imported and induced to vote "without a shadow of right.” The paper chastised Republicans for "sorry political training in fraud and corruption” and "evil methods." 105 It appeared the West Virginia Republicans and Goff had staked a great deal of legitimacy and good reputation on this contest and lost in some circles. This could also reflect Republican journalists' impatience with boss type figures. With the Democratic opposition divided, the election of 1888 provided an opportunity for the Republicans to win the governor's race. The state might handily elect a Republican president or representative to Congress, but the occupant of the governor's mansion, along with party control of the legislature, more accurately demonstrated where a party stood with the people of West Virginia. Republican gains in 1888 likely reflect a weakening confidence in the Democrats in many areas of the state. From a Republican point of view, they offered a former congressman and Secretary of the Navy in contrast to a provincial judge who could not debate Goff on one of the pressing national issues of the day, the protective tariff. On the other hand it may be asked whether that was a relevant issue to many voters. Political leaders and newspaper editors expressed their opinion, but little evidence exists about how those people in Hacker's Valley and other hamlets felt. Did they even care? Although Goff may have seen the mastery of the tariff issue as a strength to carry him to Charleston, more likely it was the man himself and his powerful manner of speaking as well as his Civil War service that impressed the electorate the most. Fleming did not impress many as a strong speaker, but he could count on a still

\footnotetext{
${ }^{105}$ New York Times, January 19, 1890.
} 
powerful, if divided, party to provide enough loyalty to the Democratic ticket to give him the slightest of edges. The election controversy only temporarily brought Democrats together under their party banner to beat Goff. However the next governor, Democrat William McCorkle, once again demonstrated opposition to the unbridled industrial growth supported by Camden. Divisiveness finally ended the rule of Bourbon era Democrats. $^{106}$

Why did the election produce such a close result? Ronald Lewis has suggested that by the 1880s, both political parties fell under the dominance of "big business.",107 This characterization might lead one to conclude that the parties offered non industrial voting blocs very little while providing an explanation for the narrowing gap between the two on election day. Ambler emphasized the high level of corruption that accompanied 1888's voting. It created intense bitterness, but also spawned reforms in the process designed to place obstacles in the way of illegal or unethical party influence over voters. ${ }^{108}$ Significantly, Goff made protection an important part of his campaign and the Democrats responded by promoting William Wilson as a debating partner instead of their own gubernatorial candidate. According to historian Charles Calhoun, the Republican Party made a concerted effort, beginning in 1884, to use the protective tariff to gain support in the state. At the same time, the national campaign abandoned references to the Civil War. Republican willingness to concentrate on 1880s issues rather than 1860s

\footnotetext{
${ }^{106}$ Rice and Brown, West Virginia: A History (Lexington: University of Kentucky Press, 1993), 173. Also Ronald Lewis, Transforming the Appalachian Countryside (Chapel Hill: University of North Carolina Press, 1998), 280. Governor MacCorkle fought throughout his tenure of office to push the passage of conservation laws.

${ }^{107}$ Lewis, Transforming the Appalachian Countryside, 243.

${ }^{108}$ Charles Ambler, West Virginia: The Mountain State (New York: Prentice Hall, 1940), 461-62.
} 
conflict tried to slice away at West Virginia and other Southern states’ animosity against the Republican Party. ${ }^{109}$

In the election of 1888 across the country, party competition drew closer. Grover Cleveland actually outpolled the winner Harrison by .8\% of the vote, but Harrison received two more states and sixty-five more electors. Peter Argersinger's article about Gilded Age election fraud asserted that instances of fraud reflected specific tactical considerations more than general practice. Party officials expected close results in 1888 and went to great lengths to turn out as many votes as possible. ${ }^{110}$ The national party's emphasis on economic issues drew those involved in extractive industries to support the Republican Party; dropping the bloody shirt made this easier for those with old ties to the rebellion to vote for their jobs as opposed to the Confederacy and long dead restrictions on its adherents. Between 1880 and 1888 the disparity between Republican and Democratic presidential ballots cast narrowed with each election until 1888. Advancing industrial development combined with a consistent and focused protectionist message from the GOP helped to wear down a fractured Democratic Party and erase its dominance.

The West Virginia Republican effort may not have emerged victorious in 1888, but it showed a party with more strength and vitality than it had demonstrated since the refranchisement of ex-Confederates. The bitter and close contest of this election showed increasing dissatisfaction with Bourbon Democratic rule. Although Republicans once again lost in 1892, they captured the governor's office in the same sweep that

\footnotetext{
${ }^{109}$ Charles W. Calhoun, Conceiving a New Republic: the Republican Party and the Southern Question, 1869-190 (Lawrence KS: University Press of Kansas, 2006), 201, 206.

${ }^{110}$ Peter Argersinger, “New Perspectives on Election Fraud,” Political Science Quarterly 100 (Winter 1985) : 672.
} 
brought William McKinley into the White House four years later. The Republican Party as a whole embraced industrial growth without the opposition of a large and disruptive agrarian faction and this enabled them to find increasing success as the nineteenth century came to a close. Victory did not unify the Democrats in any real sense. MacCorkle later complained that in 1889 "we who were doing the real work [of advocating for the Democratic candidate in Kanawha County] without Judge Fleming's knowledge were cavalierly left out and other people for political effect placed in charge.” He claimed that he resented this action and that it led to his own victorious candidacy for governor. ${ }^{111}$

Eventual party triumph came without the state Republicans' long time chief. Nathan Goff belonged to an older political generation defined by Civil War heroism that could almost completely define a candidate's character. Despite the immense amount of respect felt for Goff, some decided that West Virginia needed a new Republican leader. In the early 1890s, President Benjamin Harrison favored an industrialist who had only recently become a West Virginian. Stephen B. Elkins developed a variety of industries within the state and established strong political connections with people in both parties. Harrison’s federal appointments within West Virginia increasingly showed favoritism towards men loyal to Elkins rather than Goff. ${ }^{112}$

The struggle for Republican leadership in West Virginia was based more on style than values. Goff and Elkins differed little in ideology; both supported protectionism and industrial development in West Virginia. Both men supported James G. Blaine; Goff did so on the state level while Elkins worked to advance his cause on the national stage..

\footnotetext{
${ }^{111}$ MacCorkle, Recollections of Fifty Years (New York: G. P. Putnam’s Sons, 1928), 439.

${ }^{112}$ Williams, “Davis and Elkins of West Virginia: Businessmen in Politics”, 150.
} 
Goff had an advantage in his polished oratorical skills, but Elkins demonstrated more talent in organization. As an insider, Elkins could move within Republican circles with more confidence about which way the political winds blew. Early in 1888, tired of presidential politics, Blaine urged Elkins to support Benjamin Harrison, "the one man remaining who in my judgment can make the best run."113 This gave Elkins a distinct advantage over men such as Goff while endearing himself to the future president early in the election.

Goff's descent came in a very overt display of his loss of control over patronage. When Harrison returned the Republican Party to the presidency in early 1889, competing factions of the state organization backed different choices for the most important patronage prize, that of United States Attorney. Goff had served ably in that role for many years and he expected to have the prerogative of having Harrison name his choice to office, long time party chair W. J. W. Cowden of Wheeling. Supporters of Goff dutifully packed Cowden's application with descriptions of his tenure as party chair. Delegate J. W. Kirk of Putnam County informed the President that, during his time administering the party for Goff, "the Democrats have been consistently losing ground" and that their "magnificent majorities of a few years ago have been wiped out."114

Cowden's recommendations emphasized his hard work in the party organization. Very few discussed his talents as a lawyer. In comparison, the letter written by Elkins to Harrison reflects an almost calculated appearance of disinterest. ${ }^{115}$ Certainly the two had a chance to discuss matters in person. Elkins outplayed Goff by selecting a man with strong legal and political connections and experience, making it relatively easy for

\footnotetext{
${ }^{113}$ Blaine to Elkins, March 1, 1888, Elkins Papers.

${ }^{114}$ Kirk to Harrison, undated, Department of Justice Records, Record Group 60.

${ }^{115}$ Elkins to Harrison, March 8, 1889, Department of Justice Records, Record Group 60.
} 
Harrison to ignore Goff's frantic pleas. George Sturgiss practiced law in Morgantown with an established firm and had run as the Republican nominee for governor in 1880. Elkins could easily obtain this appointment for his friend because he had an insider's base that allowed him to maneuver in Washington more effectively than Goff.

Goff sent a barrage of letters in the spring of 1889 to Harrison, pleading with an unusual tone of desperation, "if you have not done so, I trust you will appoint Cowden at once.”116 Goff leaned on his friends, such as Pennsylvania Republican boss Matthew Quay, asking his personal attention to get Cowden appointed. ${ }^{117}$ Goff's enemies did not miss a chance to undermine his choice. Pierpont, who had found himself removed from the collectorship a few years earlier at Goff's request, pronounced Cowden "unfit” (which, experiencewise, may have been true.) Pierpont endorsed Sturgiss as a "friend of all and popular in the state."118 Elkins communicated little in writing to Harrison, but worked to organize his allies around West Virginia. He explained to Mason that Goff's crusading damaged state Republican influence with the President. Elkins suggested that Mason "get some understanding." own letters and telegrams supporting Cowden, but, in the end, Elkins’ position as a national insider and friend of Harrison won out. ${ }^{120}$ Goff tried to depersonalize the conflict later in the year by soothing relations with Sturgiss, writing that he told the president that "your appointment will not be distasteful to our people, but will be most acceptable to our friends.”121

\footnotetext{
${ }^{116}$ Goff. to Harrison, Telegram March 12, 1889, Department of Justice Records, Record Group 60.

${ }^{117}$ Goff to Quay, March 7. 1889, Department of Justice Records, Record Group 60. Goff's letter was written on state government letterhead.

${ }^{118}$ Pierpont to Harrison, Department of Justice Records, Record Group 60.

${ }^{119}$ Elkins to Mason, March 4, 1889, Mason Papers.

120 Atkinson to Quay, March 13, 1889, Department of Justice Records, Record Group 60.

${ }^{121}$ Goff to Sturgiss, November 30, 1889, Department of Justice Records, Record Group 60.
} 
During the battle over the U. S. Attorneyship, both sides vied for the goodwill of Mason, who also played a role in the higher stakes battle over a Cabinet post. Elkins corresponded about placing a West Virginian besides Goff into Harrison’s Cabinet, assuming Goff's possible gubernatorial victory would leave him uninterested in a position. Elkins clearly had patronage in mind, explaining to Mason that "all our friends could be taken care of without much effort."122 Mason seemed to gravitate towards Elkins, who felt comfortable enough with his authority by December to issue marching orders to refrain from sending a delegation to Harrison over the Cabinet issue. When one went anyway, Elkins complained that they had created "hopeless confusion." 123 Within a month, Elkins received an answer on the Cabinet issue from Harrison himself that seemed to indicate Elkins had lobbied for Goff to go to the Cabinet after all. Harrison curtly informed Elkins that he would not appoint "our friend, "explaining that "Cabinet officers are not to be State bosses." ${ }^{\text {"24 }}$ Proponents of civil service reform believed Harrison would bring a return to spoils politics. However, the president was concerned to prove himself sympathetic to reform. ${ }^{125}$

Goff's rapid fall from power demonstrated the fragile nature of party authority. One shift in the political landscape could dump a boss through the cracks. Control of state patronage built up during the Grant years faltered somewhat during the time of President Hayes. However, neither the reforming Hayes Administration, a hostile Arthur presidency, nor the Democratic term of Cleveland permanently harmed Goff because no Republican alternative was available. Then came Elkins, and Harrison switched to the

\footnotetext{
${ }^{122}$ Elkins to Mason, November 22, 1888, Mason Papers.

${ }^{123}$ Ibid, December 27 and 28 1888, Mason Papers.

${ }^{124}$ Harrison to Elkins, January 18, 1889, Elkins Papers.

${ }^{125}$ Summers, The Gilded Age, 213-14.
} 
more palatable option. Goff's renowned speaking abilities, popularity, and electoral victories could not help him in the end. It came just as suddenly as the self-inflicted political suicide some years earlier of Roscoe Conkling, although Goff was a victim of being outmaneuvered. Goff and Conkling did share an imperious nature that grated on the nerves of many above and below. The West Virginia boss's haughty tone in letters about patronage, his "reluctant tribune” posturing, and his treatment of the statemakers must have created silent enemies. Nor did Goff disappear completely from the stage. Elkins found him an honorable position as a federal judge on the Fourth Circuit while never ceasing to worry about him. Goff occasionally corresponded with Elkins on political issues, including in 1891 about their mutual friend "Major McKinley” (future President William McKinley. ${ }^{126}$ He never did leave his name on the West Virginia landscape in the same manner as Stephen Elkins, Henry G. Davis, or Johnson Camden, but his work helped to build a West Virginia Republican Party capable of competing for power.

Despite his fall from state authority, Goff remained a national figure among Republicans. He became a spokesman for a proposed national law to regularize and clean up local elections, stating "honest men of all communities shall write in requesting honest men to see that an election is honestly conducted."127 Additionally, he served in executive positions in Republican clubs and leagues and continued to support his favorite issue, the protective tariff. Typically, as Goff traveled and spoke, groups remembered the failure of 1888 by introducing him as the "elected Governor” of West Virginia. ${ }^{128} \mathrm{He}$ spent much of his time after defeat tending to business affairs and actively participating

\footnotetext{
${ }^{126}$ Goff to Elkins, July 22, 1891, Elkins Papers.

127 “Address to Young Republicans of Philadelphia,” Goff Papers.

${ }^{128}$ McDougal to Goff, March 17, 1891, Goff Papers.
} 
in that industrial thrust sponsored by men like Elkins that powerfully transformed West Virginia in these years. In late 1891 Elkins and Harrison decided to remove Goff from state politics by granting him a respectful alternative, appointment to the federal bench. If Goff felt resentment at being moved aside for the ambitions of younger men, he may have reflected upon his own ascension to power. His mouthpiece, the Clarksburg Telegram, only radiated admiration for Elkins, stating that he had been doing "wonders for the state" and was "one of the great Americans of the age." 129 Interestingly enough, long after the death of Stephen Elkins, Goff returned to become a power broker in the West Virginia party after the First World War. He did not wither away.

History does not simply record the final tally of an election in numbers of voters for candidates, but the overall effect of that event in subsequent years. Although in the short term it appeared to have been a disastrous defeat for the state Republican Party, the 1888 defeat exposed the competing factions among Democrats that could only reconcile in extreme difficulty and then only temporarily. History records the fact that 12,000 more voters cast their ballots in that election than were actually enrolled at the ballot box. Williams commented that this represented "the most corrupt and fraudulent" election in West Virginia history, certainly a tremendous feat. The Democratic Party exerted great efforts to carry this election, "Elkins' forces were more sinned against than sinners.”"130 Republican rejuvenation of party and organization prepared it to exploit Democratic factionalism eight years later and then take a commanding role for most of the ensuing generation. On a personal note, the defeat also signaled the end of Goff's reign as party leader, although that took some time to develop as well.

\footnotetext{
${ }^{129}$ Smith, Nathan Goff Jr ., 231.

130 John Alexander Williams, "New York’s First Senator From West Virginia: How Stephen B. Elkins Found a Political Home,” West Virginia History 21 (January 1970): 73-87.
} 
Goff remains a fascinating figure in state history. His stock with the people lay in his military deeds and his political abilities in contrast with Elkins, who, like Camden and Davis in the opposing party, was above all an organization man. Elkins and his colleagues in the Democratic leadership wanted to blend politics with the needs of industrial development. For them the idea of a constituency included Standard Oil and the B\&O Railroad as much as the people who cast ballots. In their thinking, this made sense. They believed that development would bring a prosperity that benefitted everyone. Only time would tell if this new era in political thinking for West Virginia would produce dividends, disaster, or both. 


\section{CHAPTER SIX}

\section{STEPHEN B. ELKINS AND MANAGEMENT STYLE LEADERSHIP}

Stephen B. Elkins exploded into West Virginia Republican politics with the power and suddenness of a Mongol horde, but prefaced by the quiet subtlety and maneuvering of a medieval papal election. Like those feared horsemen of the Middle Ages as well as the political figures inspired by Machiavelli in early modern times, campaigns planned well in advance marked out the arrival of the irresistible conqueror. Elkins emerged in West Virginia at a crucial moment in the state's history as well as his own life. In the 1880s Elkins, a man with a "round, innocent face” like an "aging baby," had made his name as a power broker on behalf of the popular James G. Blaine. ${ }^{1}$ He represented a new breed of political organizer, more inclined to the soft sell, less flamboyant, and more dedicated to building a party rather than personal loyalty. History does not always embrace the industrialist bosses affectionately, but they do bring substantial strengths and flexibility to the position. Flexibility and organization helped Elkins take advantage of the changing nature of the West Virginia economy and the financial crisis of 1893 to oust the Democratic Party from its position of dominance. Eventually, he ascended to the United States Senate, joining other Republican political authorities such as Tom Platt and Mark Hanna.

Elkins helped to drive a Republican Party trend away from powerful chieftains such as “Lord” Roscoe Conkling of New York or Nathan Goff in West Virginia. To the new breed of industrial era organizer, the Civil War existed as a memory rather than an

\footnotetext{
${ }^{1}$ H. Wayne Morgan, From Hayes to McKinley: National Party Politics 1877-1896, (Syracuse: Syracuse University Press, 1969), 179.
} 
issue. Such men would eventually bleach out the political bloody shirt. They also generally put party above personal position. This new generation preferred friendly persuasion to ruthless confrontation. It did not always create a party fearful of its leader, as Elkins saw during most election cycles, from the time he took over until the day he died. It did provide for a smooth transition, at least publicly, between powerful figures. Tom Platt eased Conkling back into full time corporate law in New York City; Mark Hanna of Cleveland outmaneuvered and displaced die hard bloody shirt wavers such as Joseph "Fire Alarm” Foraker; and Stephen Elkins managed to kick Goff upstairs to a federal judgeship in West Virginia. Historian John Alexander Williams referred to this as Elkins' greatest success. ${ }^{2}$

Elkins appeared in West Virginia politics with a much different perspective. A native of Ohio, Elkins moved west as a young man. He claimed Civil War service, although his brief stint in the pro-Union Kansas militia did not define a large portion of his personal identity as was the case with Goff. In many ways Elkins represented the new Republican Party. By the 1880s, men like Elkins held a deep respect for those who had sacrificed for the Union, but the Civil War and its aftermath no longer provided their main issues. A long string of state and local leaders in the 1870s and the 1880s served as Union officers or had some kind of other military distinction. Goff's prisoner of war status was one such experience. By the 1880s West Virginia politics centered more around the debate over industrialization rather than memories of a conflict two decades in the past. For Elkins, business provided a model through with which he operated in the world.

\footnotetext{
${ }^{2}$ John Alexander Williams, “New York’s First Senator From West Virginia: How Stephen B. Elkins Found a New Political Home,” West Virginia History 21 (January 1970) : 73-87.
} 
Elkins' defining activities occurred after his service. After earning a law degree from the University of Missouri, he went to New Mexico and made a fortune in land speculation. For Elkins and many other politicians in both parties during this era, business and politics formed a tight relationship. The loose ethical standards and legal codes encouraged situations that would in later times be seen as conflicts of interest. Johnson Camden's combination of work for Standard Oil and leadership in the Democratic Party raised few eyebrows outside of the Agrarian politicians.

Elkins commenced both of his careers in New Mexico Territory prior to the end of the Civil War. By 1864 he won election to New Mexico’s House of Representatives, and, within a few years, served as attorney general for the territory. From 1873 to 1877 he served in the United States Congress as a representative from that state. Meanwhile, he invested money in resource-bearing lands that helped to make him a wealthy individual. At times Elkins took advantage of disputed claims inherited from the chaotic Mexican and Spanish grants. Similarly, West Virginia had problems with property claims due to Virginia's shoddy organization in land grants and sales, both as a colony and a state. In 1875 Elkins moved east and married Hallie Davis, daughter of Henry Gassaway Davis of Piedmont. He then settled in New York and worked his way into national politics. Elkins supported James G. Blaine’s multiple attempts at the presidency. Both men shared a belief in the power of capital to improve the condition of the United States and its citizens. Blaine detested slavery and secession and the rest of his life associated the Democratic Party with those twin evils. As a Speaker of the House in the postwar years, he consistently supported the interests of business and felt no reason to hide his admiration of wealthy Republicans. Unfortunately for him, he also accepted gifts from 
those entities, such as the Little Rock and Fort Smith Railroad, which benefited from legislation he supported. ${ }^{3}$

The personality of Elkins reflected a personal magnetism and charm shared by Blaine, and they enjoyed the exchange of ideas. ${ }^{4}$ He and Henry Gassaway Davis readily helped Blaine establish contacts with such industrialists as Andrew Carnegie. A genius of organization, Elkins constructed highly effective campaigns for Blaine. He brought to these organizations a set of capable subordinates who managed the "Plumed Knight's" political career with an aggressive, but tactful style. However, Blaine could not overcome his own reputation when engaged in presidential elections. Even when other candidates later fought for the nomination, Elkins was a prized ally. As a "Blaine man," he could produce supporters for men such as Benjamin Harrison when "the Plumed Knight” was no longer a serious contender. During the election of 1892, Blaine saw his own candidacy as damaging to the Republican Party, so Elkins threw his support to Benjamin Harrison. Blaine followed Elkins’ rise with much interest, for instance, complimenting the West Virginia boss on his "address at Morgantown” which “was really admirable. ${ }^{5}$

Elkins helped Blaine gain entry into an important center of influence in American finance and politics, Henry Gassaway Davis’ Deer Park. This resort near Oakland, Maryland entertained some of America’s premier political and economic figures in the late 1800s. Central Appalachia's ridges rise to around 3,000 feet or more, but generally have very level tops. In summer, the temperatures range from five to

\footnotetext{
${ }^{3}$ Blaine received a $\$ 64,000$ loan from this institution and never repaid it. Charles Judah and George Winston Smith, The Unchosen (New York: Coward-McCann, 1962), 54-55.

${ }^{4}$ John Alexander Williams, West Virginia and the Captains of Industry (Morgantown: WVU Library, 1976), 30.

${ }^{5}$ Blaine to Elkins, July 8, 1888, Elkins Papers.
} 
almost fifteen degrees cooler than nearby lower elevations, and the humidity generally remains in a more comfortable range. This made Deer Park a pleasant escape from one of the industrialized world's most unpleasant summer capitals. Deer Park consisted of a luxurious hotel with cottages hidden around the grounds. Elkins had his own cottage as did B\&O official John Garrett (whose name was affixed to the surrounding county in 1872.) Deer Park had the aura that surrounds any establishment frequented by the wealthy and/or powerful. It was a center of action.

As he grew into a powerful figure in the national Republican Party, Elkins turned his financial attention to the home state of his father-in-law. Davis and Elkins combined to construct railroads that pushed deeper into the resource rich mountains and hills of West Virginia while connecting those regions to markets. These feeder railroads did not have the same legendary national reputation of a Baltimore and Ohio, but they earned profits for their builders. Davis constructed the Western Maryland, referred to as "an engineering feat." ${ }^{, 6}$ Elkins meanwhile built the West Virginia Coal and Coke. This railroad did not merely pass through the state in a pattern that connected east to west; it concentrated on linking cities within the state. This enabled better communication between the state capital and other regions while helping institutions such as West Virginia University gain more usefulness. Elkins and Davis enjoyed good relations with the Baltimore and Ohio until 1888 when it passed under the influence of the Consolidation Coal Company, a competitor with their interests.

Elkins entered West Virginia politics in the late 1880s although, according to Williams, as late as 1884 he still had not seriously considered West Virginia as a possible

\footnotetext{
${ }^{6}$ Charles Ambler, West Virginia: The Mountain State (New York: Prentice Hall, 1940), 479.
} 
political home. ${ }^{7}$ However, Elkins established useful connections within the state party well before his 1888 entry. Elkins wrote John Mason, former Union major and mid level West Virginia Republican figure, repeatedly in $1880 .^{8}$ In 1883 Mason received an invitation to meet Elkins. ${ }^{9}$ Elkins may have started implementing his plans to enter West Virginia politics in 1887 when he summoned Mason to meet with himself and Davis. ${ }^{10}$ He invested in the Wheeling Intelligencer and started making appearances. On January 2, 1888, he spoke to the Parthenon and Columbia literary societies at West Virginia University. Charles Burdette Hart of the Intelligencer arranged to hold a prosperity convention at Wheeling early in the year and earnestly sought Elkins' presence. "You will fit in very snugly. This thing you must do," Hart assured him. ${ }^{11}$

Elkins brought to the West Virginia Republican Party experienced and skilled leadership. Management of presidential bids and strong connections with the most powerful in the party gave him advantages in obtaining patronage for his supporters. In 1889, Elkins had the ear of President Harrison and the selection of his lieutenant to the prized office of U. S. Attorney confirmed it. To achieve this, Elkins had to unseat a wily and entrenched Goff and also manage to gain the support of local leaders. Goff's power base relied very strongly on his ability to deliver jobs to his friends. Once he lost that, he remained well known and popular, but without authority. Republicans respected him for past achievements, but Goff held little real authority within the party. Elkins worked over the years, especially after his election to the U. S. Senate in 1894, to broaden his

\footnotetext{
${ }^{7}$ John Alexander Williams, West Virginia and the Captains of Industry (Morgantown: West Virginia University Library, 1976), 31.

${ }^{8}$ Elkins to Mason, May 21, 1880; Elkins to Mason December 1, 1880; Elkins to Mason December 9, 1880, Mason Papers.

${ }^{9}$ Elkins to Mason, August 13, 1883, Mason Papers.

${ }^{10}$ Elkins to Mason, November 3, 1887, Mason Papers.

${ }^{11}$ Hart to Stephen B. Elkins February 6, 1888, Elkins Papers.
} 
power beyond patronage, anticipating the moves of later holders of that office from West Virginia in trying to increase federal investment in the state. ${ }^{12}$ For a time, Elkins had to remain wary of Goff. During the remainder of the 1880s and into the 1890s Elkins and Goff circled the West Virginia political ring as heavyweight prizefighters. Always reluctant to engage each other directly, Elkins constantly sought out ideas on Goff's motives or actions. He remained prepared for Goff to rebel against the subordinate position in which Elkins had boxed him, but this never happened, at least overtly.

Managing a state political party resembles in some ways the herding of cats because of its disjointed, almost feudal structure. A state party chair has titular authority, but county executive committee chairs wield considerable strength, and county party organizations have their own priorities. Obtaining support can prove difficult when interests conflict, such as when Goff received the nomination for governor in 1876, but faced anger from the Berkeley County Executive Committee because he had taken it from their favorite son candidate. Many counties, then and now, see their situation as pivotal and requiring special attention from party leadership. George Work, the Sistersville postmaster, urged Elkins to go to his county, stating that "it is necessary for you to make a trip here as soon as possible and get the boys in line.”13 Some counties resented what they saw as dictation from party and elected leaders. E. J. Allen of Taylor County informed Elkins that “(U. S. Congressman) Dayton has withdrawn that ugly letter he sent me and admits I was right in my opinion relative to allowing the Republicans of Taylor County to have free expression and not undertake to pack the convention." ${ }^{14}$

\footnotetext{
${ }^{12}$ Chief of Weather Bureau to Elkins, December 3, 1898, Elkins Papers. Location of weather station at Elkins "will be of much benefit to your town and immediate vicinity."

${ }^{13}$ Work to Elkins, April 16, 1900, Elkins Papers.

${ }^{14}$ Allen to Elkins, April 21, 1900, Elkins Papers.
} 
The divided power structure created difficulties, but not impossible obstacles. When patronage failed to deliver enough jobs, qualified men could often find employment with Elkins or one of his networks of industrial allies. Goff also lacked direct connection to the network of friends that Elkins had created. Personality, patience, and sound judgment finished the job. Goff relied upon occasional access to patronage, political skill, reputation, and charisma. Elkins had great political abilities plus money. His victory over Goff for control of the state party was not inevitable, but Elkins held a strong hand. Elkins’ ascendency into Harrison’s Cabinet as Secretary of War in 1891 gave him prestige and further nationalized his outlook. Later as U.S. Senator, Elkins faced real difficulties in balancing national, state, and local priorities.

Elkins could not gain power through sheer financial largess; he needed allies among Goff's former supporters. Party operatives perceived that in Elkins they had a much more powerful distributor of patronage than Goff. Patronage applicants generally assembled a packet of letters of recommendation from local and statewide figures. Before 1896 some writers simply put "to whom it may concern," or addressed letters to the Cabinet secretary or president himself. After 1896, almost all letters of recommendation went directly to Stephen Elkins. When L. D. Thaft wrote to Elkins in support of Gordon Gibbens receiving a marshalship, he bluntly stated "it is generally conceded that you will control the appointment for U. S. Marshal for this state." ${ }^{\text {E }}$ Elkins controlled every Justice Department appointment and most people reasoned that he had direction over all other jobs as well. There were just as many positions as before, but Elkins had more control in his time than Goff enjoyed previously. Applicsnts included the ambitious Nathan B. Scott and the popular George Wesley Atkinson.

\footnotetext{
${ }^{15}$ Thaft to Elkins, December 14, 1896, Department of Justice Records, Record Group 60.
} 
The supporters that Elkins eventually won over testify to the breadth of his influence. When Elkins eventually assumed control, he relied upon state party chair and former newspaper editor William Mercer Owens Dawson. Dawson acted as a cipher for Elkins to an extent. But Dawson did not fit the mold of a party hack; instead, he was a man who served out of conviction. Over his entire career, he showed a strongly progressive nature by advocating for government investment in good schools and roads. In 1881, Dawson became the youngest man at that point to be sent to the State Senate. There, he supported a resolution calling upon West Virginia's congressional delegation to support railroad regulation. Eight years later he wrote that "Mr. Elkins is the sort of man West Virginia needs. He is not only enterprising, but aggressively so ... he is a sound protectionist, a Republican, a student, a scholar, and a gentleman.” ${ }^{\text {16 }}$ Later, as governor, Dawson supported raising taxes on corporations, bringing "great howls from the industrialists.” He also complained of mine guard "outrages."17 After his death, he was remembered as “just about as rugged an individual as you'll ever find and his life was just about as rough as his beard." ${ }^{18}$ Elkins did not shrink from relying on an independent man of conviction to help him organize and run the state GOP. It helped Elkins considerably that the official face of the state Republican Party was a man who had spent the previous two decades perfecting his craft of communication and backing reforms of improvement for the state.

Goff did not recede quietly or quickly. Party faithful and leaders alike continued to look to Goff for leadership for years after Elkins actually gained the upper hand in political authority. Charleston lawyer Hugh Boggs sent his appreciation to Goff for his

\footnotetext{
${ }^{16}$ Preston County Journal, March 28, 1889.

${ }^{17}$ West Virginia Hillbilly, January 12, 1957.

${ }^{18}$ Ibid.
} 
employment as an abstractor with the 1890 Census, but later harangued him for a better, permanent position. ${ }^{19}$ A better position was also exactly what Elkins and his allies had in mind for Goff. His senatorial ambitions remained strong, but they conflicted with Elkins' own plans. Goff also found limits on his influence over patronage, such as when the Treasury Department refused to dismiss an agent at his request. The agent in question benefited from a "strong appeal” from Henry Gassaway Davis. The Treasury Secretary described Davis' "kindly feeling toward our party in West Virginia” and explained that "it would be unpleasant to me, personally, to utterly disregard his wishes, as you request, and it seems to me it would not be good politics just now. ${ }^{20}$ Goff's defeat was complete when he found that a Democrat received preference at the Republican patronage trough over himself.

The unmentioned factor of that letter was obviously Davis' son in law, Elkins. Elkins had similar problems in that President Harrison did not wish to challenge Goff directly. The two men finally met at Davis' Baltimore office to determine how to proceed. Neither wanted an open break that could lead to conflict just as the state party had clawed its way back to dominance. Goff also remained popular in the state and national party and some continued to try to use him as a counter-balance to Elkins. Charleston interests seeking to consolidate that region's Republican newspapers sought to play Goff and Elkins off each other to draw financial support. ${ }^{21}$

Goff would not achieve his dream of a Senate seat until well into the next century after the death of his rival, but Elkins did ensure that Goff received an honorable and safe position. The appointment to the federal judiciary removed Goff from active

\footnotetext{
${ }^{19}$ Boggs to Goff, March 3, 1890 and December 5, 1890, Goff Papers.

${ }^{20}$ Mindow to Goff, July 5, 1889, Goff Papers.

${ }^{21}$ Mahone to Goff, April 7, 1891, Goff Papers.
} 
involvement in politics while granting him his due as the man who rebuilt the party. His acceptance of the position brought congratulations that fell short of enthusiasm. The hyperbolic Atkinson, now a member of the House of Representatives, explained that "the people are generally mad because you go out of active politics and they say we can not do without you.”22 For Atkinson and other long time Goff supporters, the disappearance of their benefactor may have appeared ruinous, but Elkins had no intention of freezing out all of his former rival's men. Atkinson won the governor's office in 1896 and served adequately, promoting industrialism but also limits on child labor. Others looked for new champions to fight against the increasing dominance of Elkins. A Kingwood Republican recognized the tightening velvet-gloved grip of Elkins and tried to spur his congressman into action, complaining that "General Goff is ignored.” Congressman Alston Gordon Dayton tried to remain aloof of controversy involving the Republican leader and his allies. ${ }^{23}$ Nevertheless he tried to remain on good terms with Elkins’ allies such as George Sturgiss and John Mason. However Sturgiss relayed to Mason that Dayton was “sensitive, fiery,” and “indiscrete [sic].”24

Elkins had powerful allies aiming to build his base of power in West Virginia. As Nathan Goff benefited from an appointment to the Cabinet, so would Elkins. Goff held a very brief and almost ceremonial tenure as Secretary of the Navy while Elkins controlled the Department of War between 1891 and 1893. Nathan B. Scott, elected to the U. S. Senate not long after Elkins, advised President Harrison in 1891 that appointing Elkins to the Cabinet would invigorate West Virginia Republicans to continue the gains made in

\footnotetext{
${ }_{22}^{2}$ Atkinson to Goff December 21, 1891, Goff Papers.

${ }^{23}$ Heermans to Dayton July 16, 1890, Dayton Papers.

${ }^{24}$ Sturgiss to Mason August 31, 1894, Mason Papers.
} 
the 1880s. ${ }^{25}$ The appointment unsettled those still committed to seeing James G. Blaine as president because they understood Elkins and perhaps Blaine himself had abandoned that notion. Although Elkins had a good reputation for congeniality, relations between Harrison and himself grew more prickly over time, which could have proved difficult had the president won a second term. Harrison readily admitted his shortcomings in personal situations. Although a magnetic speaker, he often acted coldly or rudely toward allies. Before going to a political function, his friend John New advised, “For God’s sake be a human being down there. Mix a little with the boys after the meeting." Harrison had to admit later that he had tried and failed. Tom Platt, New York’s famous “Easy Boss” expressed uneasiness with Harrison, saying “Those who did the most to please Harrison . . found him a marble statue when they asked for recognition of their services."26 Elkins later expressed in frustration, “God Almighty’s overcoat would not make a vest for Harrison. ${ }^{27}$ As a state level manager, Elkins had to satisfy and conciliate not only restive lieutenants, but also important figures on the national stage.

Elkins was more than just a party boss looking for prestige. When he achieved high level positions, he looked for ways to advance positive changes. Secretary of War Elkins pushed to raise the salaries of non commissioned officers while expanding the role of the Division of Military Intelligence. Elkins gained broader perspective on America's place in the world while serving in the Cabinet, noting to Andrew Carnegie that "the Atlantic Ocean is only a wide river.” He also formed a geo-strategic philosophy in which he foresaw sixty years before it occurred world domination by “Anglo-Saxons,” Russia,

\footnotetext{
${ }^{25}$ Scott to President Harrison, October 29, 1891, Elkins Papers.

${ }^{26}$ Thomas Platt, Autobiography of Thomas Collier Platt (New York: B. W. Dodge and Co, 1910), 252.

${ }^{27}$ Morgan, From Hayes to McKinley, 289, 328, 330.
} 
and China. ${ }^{28}$ Elkins also voiced concern over the political power of the great monopolies after Standard Oil influenced a congressional committee vote on tariffs; "This has excited a great deal of criticism in Washington, people question how these great corporations can succeed while others fail.”29 Such statements further contradict the contention that Elkins formed part of a monolithic network of businessmen seeking to gain political power and economic control at all costs.

Goff did not cease to trouble Elkins after ascending to the judiciary, however. Three years after Goff's appointment, Elkins still feared his influence. Relations between the two ranged from amiable to strained. An 1891 letter from Goff advised Elkins in an almost friendly manner about the rise of an Ohio politician, Major William McKinley. ${ }^{30}$ Regardless, they remained rivals for the U. S. Senate. Elkins stated to Mason that Goff was maddening and possibly still longed for a seat. Elkins had to balance that against the ambitions of his own sometimes troublesome lieutenant, Sturgiss. ${ }^{31}$ In 1894 Elkins had aimed to secure the prize for himself. By December of 1894, once again Goff and Elkins came to "understand each other perfectly." Goff instructed his Harrison County friends to vote for Elkins, an effective silent endorsement. ${ }^{32}$ According to Elkins, Goff also agreed to abstain from running for the U. S. Senate. In return, Elkins ensured that Goff received consideration for the vice presidency. ${ }^{33}$ Sturgiss sulked at not receiving any positive mention, but did not rebel.

\footnotetext{
${ }^{28}$ Elkins to Carnegie, May 13, 1893, Elkins Papers.

${ }^{29}$ Elkins to Davis, December 10, 1893, Elkins Papers.

${ }^{30}$ Goff to Elkins, July 22, 1891, Elkins Papers.

${ }^{31}$ Elkins to Mason, November 16, 1894, Mason Papers.

${ }^{32}$ Ibid, December 18, 1894.

${ }^{33}$ Elkins to White, December 26, 1894, Albert Blakeslee White Papers, West Virginia Regional and History Collection, West Virginia University, Morgantown WV. Hereafter referred to as "A. B. White Papers.”
} 
While fulfilling his duties as United States Senator, Elkins never let his attention waver from the details of running the state party. His first term in the Senate saw the United States enter war with Spain. Elkins enjoyed good, if not warm, relations with the president and dutifully supported his policies. He owned a stake in the conflict in that his son, Fred, had received recommendation for an officer’s commission from General Joseph Wheeler. ${ }^{34}$ Elkins supported an aggressive policy, partly out of fear that the German Empire had designs on territory in the Western Hemisphere. Some of his colleagues disagreed with the administration. Massachusetts Senator Henry Cabot Lodge feared that seizing the Philippines gave the Democrats "a line of attack where we cannot meet them.. ${ }^{35}$ Elkins gradually gained a respectable grasp on national issues that placed him in line, by the early twentieth century, to possibly succeed William McKinley as president.

Elkins, according to some sources, may have promised to match other Republican campaign contributions dollar for dollar in 1892 in exchange for the US Senate seat. ${ }^{36}$ Dawson managed the money and distributed it effectively. All did not always work perfectly because Dawson did not exercise complete control over all party officials. In November 1896 he wrote a stinging letter to John Mason, asking him to find out what happened to contributions made specifically from Mason's home county of Marion. Two middle men named Fleming and Showalter had received $\$ 1,000$ total including $\$ 600$ from Elkins himself, but only reported $\$ 150$ to the state executive committee. Dawson fumed that a donor named Dobbins had refused to send any more money to Marion

\footnotetext{
${ }^{34}$ Wheeler to Elkins July 11, 1898, Elkins Papers. Wheeler is one of the rare examples of a Confederate general commanding United States forces in the field after the Civil War.

${ }_{35}^{35}$ Lodge to Elkins undated, Elkins Papers.

${ }^{36}$ Williams, West Virginia and the Captains of Industry, 53-54.
} 
County "until that matter is straightened up and the money accounted for.” Dawson condemned the laxity of the Marion County organization, claiming that Dobbins "spoke about this thing happening once or twice before in reference to Marion County ... Money should not have been 'used' in a private way.” He summed up by informing Mason that "a great deal of money has been wasted in this campaign by having been given without the knowledge of the State Committee. I do not know why our people insist on doing business in this way." ${ }^{37}$

Dawson, a future Republican progressive leader in West Virginia, sought to clean up some of the electoral process. In 1896 he wrote a scathing letter to Congressman Dayton, a resident of Philippi, about his home county’s electoral practices. Dawson regretted "very much the condition of affairs in Barbour County." He recommended that Barbour County receive no more money than absolutely necessary for "legitimate work." Barbour County had, according to the state chairman, fallen into corruption via "lavish use of money, whiskey, and other 'abhorrent forces.” He contrasted Barbour against the apparently relatively pure conduct of Preston and Monongalia. Dawson contradicted the conventions of his time when he told Dayton that "no political party can be permanently built up by methods that have been pursued in Barbour since I have been Chair of the State Committee.” He then asked Dayton to suggest changes in election laws. ${ }^{38}$ Although part of the outrage certainly had genuine origins in the progressive mindset of Dawson, likely the parsimonious Elkins also despised the utter waste of cash. Later, when he sponsored the landmark act preventing the issuance of rebates by railroads, Elkins probably combined virtue with saving money.

\footnotetext{
${ }^{37}$ Dawson to Mason, November 16,1896, Mason Papers.

${ }^{38}$ Dawson to Dayton, November 11, 1896, Alston G. Dayton Papers, West Virginia Regional and History Collection, West Virginia University, Morgantown WV. Hereafter referred to as Dayton Papers.
} 
Elkins continued to maintain a strong presence in the state. One of the twentieth century’s greatest politicians explained that “you can be the most important congressman in the country, but you had better not forget the people back home.”39 He continued to make speeches in isolated county seats such as Moorefield and courteously received letters from local political figures and job seekers. The Tyler County Sheriff was quick to explain the slight Republican majorities to Elkins in the election of 1898, blaming them (typically for most localities) on discordant elements. However he credited Elkins for holding meetings in Middlebourne and Sistersville that "did much to harmonize differences and put the boys into active service for the party.”

The close loss of the Republican Party in the election of 1888 thus set the stage for the party’s later success. Elkins rose into a leadership position, using his managerial style to reorganize the party while addressing the concerns of many who had supported Goff. Elkins, however, did not wrench this political ship in a new direction without some help from the political currents of the time. Economic disaster on the Democrats' watch made the economic arguments of the Republicans much more relevant to voters. In the years leading up to 1896, Republicans within West Virginia and around the country worked to build their party and educate voters. In that year, they wrenched formerly Democratic states into the GOP column and laid the foundation for the latter party's dominance for a generation.

\footnotetext{
39 Thomas P. “Tip” O’ Neil, Man of the House (New York: Random House, 1987), 26.

${ }^{40}$ Pyle to Elkins, November 11, 1898, Elkins Papers.
} 


\section{CHAPTER SEVEN}

\section{ELECTION OF 1896}

The Republican Party hit a watershed year in 1896. Across the country people turned out to vote William McKinley president of the United States. It marked a turning point for the party, the country, and the world. Throughout McKinley's administration activist groups pushed for a stronger U. S. presence in foreign affairs. ${ }^{1}$ The European balance of power was about to shift, even as it claimed ascendancy over almost every continent and ocean. Meanwhile America, Germany, and Japan moved closer to the day when they would project their own power beyond their shores. Historians often mark Theodore Roosevelt as the first modern president, but McKinley really marks the beginning of twentieth century America. His election resulted from a basic shift of states and constituencies from the Democratic to the Republican column. West Virginia participated in this movement by evicting Democrats from legislative control in 1894 joining fellow border states Maryland, and (except for one elector) Kentucky to vote for McKinley in 1896.

The 1890s marked the climax of a long term shift in the Republican dynamic, both in West Virginia and across the nation. It gravitated away from bosses specializing in personal authority to corporate style managers. It also almost completely abandoned the bloody shirt and embraced a cohesive economic platform. Meanwhile Democrats split on issues such as the tariff and currency policy. In West Virginia the splits almost formed into schisms and left the party defenseless to a concerted GOP charge. West

\footnotetext{
${ }^{1}$ Paul Kennedy, The Rise and Fall of the Great Powers: Economic Change and Military Conflict From 1500to 2000(New York: Vintage Books, 1989), 245-246.
} 
Virginia's Republican momentum grew during the late 1880s and 1890s owing not only to its own work and message, but also as a result of the slow breakdown of the Democratic Party. Where the Republicans generally had very clear leadership between the early 1870s and the early 1900s, their opponents suffered increasing divisions. Agrarian Democrats embraced what many called at the time conservative values, opposing industrialism. Other Democrats shared some of the same development goals for the state trumpeted by Boreman when he was governor, following that party's industrialists.

Economic crisis in the early 1890s confirmed in the minds of some voters the wisdom of Republican economic philosophies, particularly the emphasis on protectionism. Murmurings of economic crisis circulated in the border state and Southern regions in 1892. In November, representatives of the major Southern oriented railroads met in Chattanooga to address the issue of a "demoralized condition of rates throughout the South.”² Davis’s Western Maryland railroad sent its president, John B. Hood. Kentucky boss and Louisville and Nashville Railroad president Milton Smith also attended. The group agreed to try and halt the decline in rates, taking control over pricing from “a few shippers.”3 By the beginning of 1893, pessimism set in as domestic and international factors weighed on the minds of investors. Agricultural produce fell short of expectations and Europe showed “deepening poverty," partly related to a cholera plague. Some held out hope that a rise in stock prices might show an increase in prosperity, but that did not occur. ${ }^{4}$ Instead, economic panic set in. By May the New York Times reported that "The number of failures last week, as reported by the commercial

\footnotetext{
${ }^{2}$ New York Times, November 15, 1892.

${ }^{3}$ Ibid.

${ }^{4}$ New York Times, January 1, 1863.
} 
agencies, was surprisingly large” and described a serious contraction of available credit. ${ }^{5}$ This economic crisis took place during an explosive decade of American production. The United States produced 143 million tons of coal in 1890, but increased that total by 100 million tons at the end of the century. Steel production more than doubled in the same time span. ${ }^{6}$ These events coincided with the rise in power of labor organizations, such as the United Mine Workers of America which launched strikes in Kentucky, Alabama, and Tennessee using populist style rhetoric. ${ }^{7}$

The infamous Pullman Strike of 1894 illustrated the growing problems and social divisions. George Pullman's paternalistic company community erupted into violence after a $70 \%$ cut in pay and little corresponding relief at the company stores. ${ }^{8}$ The strike and resulting violence shocked the nation and even some labor sympathizing voters in the next elections saw maintenance of rule of law as a priority. ${ }^{9}$ The United States economy had collapsed, and it threatened to drag the social order down with it in the minds of many. Voters believed that the Republican Party offered possible answers to the troubles afflicting the nation in 1894 and 1896 and voted accordingly. Hard times during a Democratic presidential administration combined with rising organization and political skill in the Republican Party both in West Virginia and around the nation to produce a context that explains GOP gains in the mid 1890s.

This period contrasted with politics over the preceding twenty years. For much of the 1870s, Republicans featured Ulysses S. Grant and Roscoe Conkling as two of their

\footnotetext{
${ }^{5}$ Ibid., May 21, 1893.

${ }^{6}$ A. J. P. Taylor, The Struggle For Mastery In Europe, 1848-1918 (Oxford: Oxford University Press, 1954), xxix-xxx.

${ }^{7}$ John Alexander Williams, Appalachia (Chapel Hill: University of North Carolina Press, 2001), 263.

${ }^{8}$ Mark Wahlgren Summers, Gilded Age or the Hazard of New Functions (Upper Saddle River, NJ:

Prentice Hall, 1997),, 241.

${ }^{9}$ Ibid, 244.
} 
main driving forces. Grant, like many nineteenth century presidents, did not bring a grand vision to the White House, but instead reacted to events as they occurred. Fellow senator Chauncey Depew concluded that Conkling’s “wonderful gifts were wholly devoted to partisan discussions and local issues."10 In 1880 a Texas delegate in convention asked "What are we here for?” He then answered his own question with "I mean that members of the Republican Party are entitled to office, and if we are victorious, we will have office!"11 Economic difficulties and financial scandals in the 1870s gave weight to Democratic arguments of Republican maladministration. Especially in 1872, GOP malcontents were only too happy to help Democrats assault Grant style leadership. In the midterm election of 1874, twenty-three of thirty-five contested states voted Democratic. Their chief asset lay not in their dynamic ideas for bringing back prosperity, but in the fact that they were not Republicans. ${ }^{12}$ The 1890 s saw a reversed dynamic. The Democratic Party divided over economic issues of the tariff and the gold standard as a financial and economic crisis spread throughout the nation. Republicans also supported the expansion of pensions for Union soldiers. Some Democrats, such as Henry Gassaway Davis, split temporarily from their party to support ideologically similar Republicans. ${ }^{13}$ The GOP’s response in 1894 to the onset of crisis proved more effective than the Democratic assault on Republicans twenty years before. Republicans in the 1890s articulated a powerful alternative vision based on sound money and protectionism and wedded it to a modern style political organization to overturn their opponents’ control of both Congress and the White House.

\footnotetext{
${ }^{10}$ David Jordan, Roscoe Conkling of New York (Ithaca: Cornell University Press, 1971), 143.

${ }^{11}$ Mark Wahlgren Summers, The Gilded Age, 179.

${ }^{12}$ Paul Leland Haworth, The Hayes-Tilden Disputed Election of 1876 (New York: Russell and Russell, 1966), 3-4.

${ }^{13}$ Davis to Dayton, September 10, 1894, Dayton Papers.
} 
The buildup to Republican success in West Virginia in the early 1890s did not occur without addressing intraparty obstacles. Some irritation over the elevation of Elkins and his lieutenants still appeared from time to time and factionalism constantly remained an issue. ${ }^{14}$ One of the up and coming political figures trying to navigate these shoal ridden seas was Alston Gordon Dayton. Dayton, whose father, Spencer, was a prominent Democrat, served as prosecuting attorney of both Upshur and Barbour Counties. Born in 1857, he came from a generation which knew the Civil War as history, not a first-hand combat experience. Dayton’s emergence into Republican politics demonstrated West Virginia's general drift towards the Republican Party in the years leading up to the great electoral shifts of 1896.

In 1890, Elkins' men had started to move the pieces into position while continuing to test the political winds. George Sturgiss worked closely with Dayton, asking advice on state Supreme Court candidates, while urging him to allow others to obtain the GOP nomination because "as to congressional matters, we are still at sea."15 However they still tried to cultivate Dayton as a candidate. Dawson complimented him on a series of speeches made in 1890 in support of the campaign and promised to "pay you back so far as I can in my feeble way."16 Dayton in1890-91 managed to maintain good working relationships with all the particulars, including Mason and Goff. ${ }^{17}$

By 1892, evidence emerges of a prickly side to Dayton’s nature. Future state Supreme Court Justice Ira Robinson had served as a legal partner to Dayton. Upon the

\footnotetext{
${ }^{14}$ Heermans to Dayton May 15, 1890, Dayton Papers. He threatens that is Elkins or Dawson receive any congressional nominations, then there will be a lot of "stay at homes" in response. E. J. Allen of Grafton wrote a few months later to convey advice that Dayton "steer clear of combinations of all kinds." This indicates some continuing discontent as well. E. J. Allen to Alston Gordon Dayton, August 16, 1890, Dayton Papers.

${ }^{15}$ Sturgiss to Dayton, August 1, 1890, Dayton Papers.

${ }^{16}$ Dawson to Dayton, October 21, 1890, Dayton Papers.

${ }^{17}$ Mason to Dayton, February 25, 1891 and March 26, 1891, Dayton Papers.
} 
dissolution of that arrangement, Robinson still owed Dayton \$24. Within three weeks, Robinson wrote Dayton a stinging letter describing an incident where Dayton requested to stay at Robinson's home. Robinson refused, so Dayton asked his wife and she assented, resulting in Dayton's making “a convenience of us ... until forbearance on our part ceased to be hospitality."18 Later that summer, Robinson noted an "insulting letter" and responded that "I do not feel the least intimidation from your threats." ${ }^{\text {,19 }}$ Dayton's explosive temper earned notice from other Republican leaders in the months leading up to the 1894 election. Sturgiss warned Mason that "Dayton is sensitive, fiery and sometimes indiscrete [sic] and ... must be handled with care."20 Such minor issues did not derail Dayton’s campaign, however.

By 1894, Dayton was ready to push for the nomination, but found opposition in former gubernatorial candidate, United States Attorney, and Elkins supporter, George Sturgiss. Early in the summer Sturgiss mused that he, Mason, or Elkins should get the nomination, feeling that an Elkins campaign for the House of Representatives would help his Senate ambitions. ${ }^{21}$ By August, he "reluctantly" informed Mason that he would be willing to have his name advanced as a candidate. Sturgiss asked Mason to help build party harmony and worried about both a "fiasco" and "ill-feeling."22 John Alexander Williams asserts that Dayton's nomination over Sturgiss represented an example of Elkins' policy of bringing new men into state politics, "bypassing older and more independent leaders."23 Some saw Dayton as a vote against the patronage system though.

\footnotetext{
${ }^{18}$ Robinson to Dayton, March 24, 1892 and April 11, 1892, Dayton Papers.

${ }^{19}$ Robinson to Dayton, July 12, 1892, Dayton Papers.

${ }^{20}$ Sturgiss to Mason, August 31, 1894, Mason Papers.

${ }^{21}$ Sturgiss to Mason, June 18, 1894, Mason Papers.

${ }^{22}$ Sturgiss to Mason, August 31, 1894.

${ }^{23}$ John Alexander Williams, West Virginia and the Captains of Industry, 65.
} 
J. F. Harrison of Piedmont assured Dayton that he wanted a Republican victory, but "we do not propose to let some of those fellows who have been feeding for time immemorial at the public 'crib’ dictate."24 Dayton and Sturgiss both had delegates lined up to support them at the 1894 congressional nominating convention, but Mason continued to lurk as a possibility to steal the prize. ${ }^{25}$

One of the key issues in the congressional election of 1894 was the tariff bill of William L. Wilson. ${ }^{26}$ Henry Gassaway Davis requested that Dayton come to confer with him in Elkins and assured him of his brother Colonel Thomas's support as well. ${ }^{27}$ Since the passage of tariff revision at the behest of Wilson and other free trade advocates, the Representative from the Second District had found himself politically and ideologically separated from figures such as Fleming and Davis. This kind of opposition, combined with the Republican surge during the economic crisis, meant that one of the congressional leaders on tariff reform faced serious trouble in his re-election efforts. ${ }^{28}$

Davis expected Dayton to serve as a protectionist voice in Congress and shared those sentiments with Intelligencer editor Charles Burdett Hart who exclaimed “Above all things, I want Wilson whipped!”29 The Republican Party nationally viewed the Second Congressional District in West Virginia as pivotal. William L. Wilson served as the House leader of tariff reformers. A strong rebuke from his own constituency not only would remove the well-spoken leader of free traders, but might undermine the entire

\footnotetext{
${ }^{24}$ Harrison to Dayton, July 31, 1894., Dayton Papers.

${ }^{25}$ William Conley, Chairman of the Tucker County Executive Committee to Alston Gordon Dayton, August 21, 1894, Dayton Papers.

${ }^{26}$ Maxwell, to Dayton, September 6, 1894, Dayton Papers.

${ }^{27}$ Davis to Dayton, September 10, 1894, Dayton Papers.

${ }^{28}$ Ken Fones-Wolf, "A Political House Re-Divided ...”

${ }^{29}$ Hart to Dayton, September 10, 1894, Dayton Papers.
} 
movement, bringing "a great national reverse to the enemy." ${ }^{30}$ Others wrote to Dayton, encouraging him to believe that all Democratic hopes rested on Wilson, who may have received financial support from British manufacturing interests. Republicans certainly believed that he did. ${ }^{31}$ The struggle against Wilson and the tariff temporarily united the party; Sturgiss sent Dayton a strong letter of encouragement and advice. ${ }^{32}$

The politics of the period were driven by the powerful changes transforming the nation. During the thirty years following the end of the Civil War, industrialization affected the country as a whole as well as West Virginia itself. It introduced accelerated development during a time of impressive economic expansion. From the start of the Civil War until 1914, American imports expanded from \$334 million to \$2.365 billion. At the same time imports increased at a much slower rate, from \$356 million to \$1.896 billion. This occurred during a period in which the United States for the most part embraced protectionism. The European colonial states could not compete with cheap American food while Britain struggled to compete with the ever expanding production of industrial goods. European tariffs only slowed the imbalance somewhat. Europeans, especially Kaiser Wilhelm II’s Germany, resented the trade imbalance and American hoarding of gold supplies. ${ }^{33}$

All those finished goods made of steel, along with all the rails and ships that carried those goods to market, required more production of coal. Railroad penetration into West Virginia’s hills and valleys started in earnest during the 1870s. These originally branched from the main lines of the Baltimore and Ohio and Chesapeake and

\footnotetext{
${ }^{30}$ Thomas McKee acting secretary of the Republican Congressional Committee to Alston Gordon Dayton, September 10. 1894, Dayton Papers.

${ }^{31}$ McWhorter to Dayton, September 22, 1894, Dayton Papers.

${ }^{32}$ Sturgiss to Dayton, September 15, 1894, Dayton Papers.

${ }^{33}$ Paul Kennedy, The Rise and Fall of the Great Powers, 245.
} 
Ohio Railroads. Some of the most important grew from the investments and work of Camden, Davis, and Elkins. These originally replaced the old and destructive methods of getting timber out of the mountains, but they also quickly grew into convenient ways to ship out coal. In 1880 West Virginia mines produced 1,680,000 short tons of coal. By 1890 that figure expanded to 7,394,000 and doubled from that number by 1897. The year 1880 also saw 472 sawmills operating in the state. Nearly a thousand processed state lumber by $1899 .{ }^{34}$ These activities did not replace agriculture, but they certainly eclipsed the old standards of wealth in the state and created new conditions. Increased production did not simply benefit the North as many states in the former Confederacy experienced growth in the production of iron and consumer goods to supplement traditional agriculture. $^{35}$

Advancing industrialism forced changes in the Bourbon caretaker state established by the 1872 constitution. The Weston State Asylum was supplemented by facilities elsewhere and the state built a reform school at Pruntytown. This relieved the county jails of the burden of housing the insane and minors. Farmers lost the ability to allow their livestock to graze freely outside their own property as extractive industries required more land. Medicine received its first regulation on the state level as well in the 1880s. This decade formed the foundation for the more significant changes that would occur during the years when Republicans dominated state politics. Historian Mark Wahlgren Summers points out that a natural dislike for government power developed in the 1870s due to bossism and Reconstruction, but that this did not prevent the growth of interventionism across the country in the 1880s. Additionally tangible results followed

\footnotetext{
${ }^{34}$ Charles Ambler, West Virginia: The Mountain State (New York: Macmillan, 1940), 481,482.

${ }^{35}$ Williams, Appalachia, 244, 245.
} 
an increase in government activity. William M. O. Dawson had advocated for good roads from the time he was a Preston County editor until he assumed the governorship of West Virginia. Free transportation, hospitals, and schools had very few able opponents. ${ }^{36}$ Summers also described the constituency of wealth as divided. Camden's complaints about steel oriented Wheeling Democrats pushing for reduced tariffs on coal illustrate the point.

Charles Ambler, John Alexander Williams, and many others create an image of business class interests taking hold in this decade. Ambler rued the idea that low tax rates prevented "the richer flowers of culture” from blossoming and blamed industrialists and their supporters for the problem. ${ }^{37}$ Williams accused leaders such as Camden and Davis (and by extension other capitalists such as Elkins) of using rail passes, patronage, and "the barrel" of favors to sway influential locals. These men supported their leaders and advanced their interests, or so it seemed. ${ }^{38}$ Some extraordinarily cordial exchanges between Stephen Elkins and Johnson Camden in 1892 and 1894 would seem to back up these claims. Elkins needled Camden about the ineffectiveness of his senatorial colleague, Charles Faulkner Jr., on the stump while requesting a higher tariff rate on coal and even asking him to get the Wheeling Register to tone down its attacks on Elkins! ${ }^{39}$ Again, the Democratic industrialists had to fight difficult ideological battles over economic policy with factional leaders. The establishment of links in 1896 with protectionist and “goldbug” Democrats made sense for the Republican leadership

\footnotetext{
${ }^{36}$ Mark Wahlgren Summers, The Gilded Age, 194, 195, 198, 199. This chapter is called "The Myth of Lasseiz-Unfaire.”

${ }^{37}$ Ibid, 459.

${ }^{38}$ John Alexander Williams, West Virginia: A History (Morgantown: West Virginia University Press, 2001), 117.

${ }^{39}$ Elkins to Camden, September 21, 1892, March 12, 1894, and August 25, 1894, Camden Papers.
} 
whether those connections occured with leaders or significant numbers of registered Democratic voters. Without a crossing of party lines, whether temporarily for voting or permanently in registration, the West Virginia Republicans could not have achieved power or maintained it for long.

The tariff discussion dominated the late 1880s and the first half of the 1890s. Nathan Goff garnered a national reputation with his eloquent defense of the protective tariff. Industrial concerns feared competition with the British Empire and other nations which presumably could undersell American products at home, especially during a time of economic crisis. West Virginia coal barons in particular lost sleep at nights over the potential market influence of coal from Nova Scotia. Democrats, on the other hand, argued that tariffs increased prices and hurt farmers purchasing finished goods. Few as yet discussed the negative impact of lessened competition on U. S. industry. The Wheeling Register drove industrial Democrats and Republicans to distraction with its constant drumbeat against the coal tariff. William Wilson pushed hard for downward revisions and criticized the "renaissance of ultra-Federalism." ${ }^{40}$ The tariff backed by Republicans such as Dayton sought to protect and promote the Second Industrial Revolution and the changes it brought to the United States.

Dayton carried the race. Republicans won all of West Virginia's congressional districts and the state legislature. The New York Times trumpeted "Democrats Lose Heavily All Over the Country." ${ }^{41}$ Preston County’s J. C. McGrew delighted in the results, stating "now is the winter of our discontent made glorious summer." ${ }^{42}$ Elkins'

\footnotetext{
${ }^{40}$ H. Wayne Morgan, From Hayes to McKinley: National Party Politics, 1877-1896 (Syracuse: Syracuse University Press, 1969), 461.

${ }^{41}$ New York Times, November 7, 1894.

${ }^{42}$ McGrew to Dayton, November 9, 1894, Dayton Papers.
} 
part in the unfolding electoral drama came next. The West Virginia Legislature had the opportunity in 1894 to choose a United States Senator. Elkins expected the party he helped to achieve this resounding victory to reward him with the seat. His first fear, naturally, was that Goff might resurrect his old ambitions, but doubted a challenge would emerge from that quarter. “I don’t think he is in the raw,” Elkins mused to Mason. ${ }^{43}$ Rumors about Goff unsettled Elkins, who asked Dayton later in November to have some "friend" talk to the former boss to dissuade him. ${ }^{44}$ From an unexpected direction came resistance to Elkins' march to the Senate. Sturgiss declared his candidacy shortly after the election.

Why did Sturgiss declare against the man who obtained for him the lucrative U. S. Attorney position some years before? Sturgiss obviously did not see the former county prosecutor Dayton as a serious challenger for the nomination. A comparison between Sturgiss and Dayton on the surface tends to favor the former, who ran for governor and faithfully served as U. S. Attorney. Sturgiss also worked loyally for Elkins and assisted in his rise. Elkins did reward him, but Sturgiss likely expected more. The loss to the less experienced and younger Dayton must have stung Sturgiss and the best explanation likely, as Williams pointed out, lay with Elkins. Elkins wondered if Sturgiss "wants somebody to promise him something," but later concluded that "his purpose is to get in line for the next time.”45 Elkins continued to fret, despite New York Times reports that a canvass of Republican legislators concluded that he would carry the election. ${ }^{46}$ In early January several regional leaders, such as Charleston’s John B. Floyd, floated their

\footnotetext{
${ }^{43}$ Elkins to Mason, November 11, 1894, Mason Papers. Also Stephen Elkins to Alston Gordon Dayton, November 14, 1894, Dayton Papers.

${ }^{44}$ Elkins to Dayton, November 13, 1894, Dayton Papers.

${ }^{45}$ Elkins to Mason, November 16, 1894 and December 14, 1894, Mason Papers.

${ }^{46}$ New York Times, November 22,1894.
} 
candidacies and expressed a willingness to stand behind Goff, but the anti-Elkins moves failed to coalesce. ${ }^{47}$ Republicans across the country reveled in the victories of that year, crediting good organization and a strong commitment to the protective tariff. In the next two years another issue would emerge that tested the fragile resurgence of the GOP, the issue of free silver and its champion William Jennings Bryan.

Coming fast to the national forefront in the 1890s was the issue of inflationary currency. US money remained "good as gold" in those days, but western silver mining interests combined with indebted farmers to push "bimetalism." This, its advocates argued, would inflate the currency and provide debt relief for small and middle sized farmers. Support for it swept the Midwest and South, but not the Grover Cleveland White House. The national fissures reflected the now decades old splits that had already disrupted the West Virginia Democrats. “Gold Democrat” Henry Gassaway Davis occasionally, albeit privately, supported sound money Republicans such as Dayton in 1894. "The boy orator of the Platte,” William Jennings Bryan thundered across the prairie into the hearts of agrarians everywhere with his consistent and powerful call for silver currency. Bryan unashamedly affirmed the divisions among the Democrats by claiming in his famous "Cross of Gold” speech at the 1896 Democratic National Convention that "Old leaders have been cast aside when they refused to give expression to the sentiments of those whom they would lead." ${ }^{48}$ Bimetalism, to those not converted to its benefits, confused (and undoubtedly bored) many voters as much as it confuses undergraduate history students today. Factory workers saw little benefit to inflating the currency when they understood better than anyone that wages lag behind prices during

\footnotetext{
${ }^{47}$ Ibid. January 5, 1895.

48 "Cross of Gold” speech, William Jennings Bryan, Democratic National Convention, 1896.
} 
such a cycle. Personally, Bryan struck some as the same old politician, "a lively sense of his ability to influence people individually and in the mass by charming manners, meaningless courtesies, pleasant words, outworn phrases." ${ }^{\text {49 }}$ The journalist William Allen White recalled Bryan’s nomination; “I was moved by fear and rage as the story came in. I had never heard of Bryan. To me, he was an incarnation of demagoguery, the apotheosis of riot, destruction, and carnage.” A fellow Republican reporter shouted to White, "Marat has won!"50

Historian Mark Wahlgren Summers claimed that, "The more Bryan spoke, the less clear it became what, besides free silver, he had to offer." ${ }^{51}$ He speculated that Bryan looked like a relic more so than the leader of a modern movement. The Democrats ran a one trick pony Jeffersonian in 1896 against one of the best organized campaign machines assembled to that point in US history. Historian Bruce Felknor analyzed the increasingly common question in 1896 as to whether or not Bryan suffered from insanity. The New York Times questioned five experts in the field of mental illness, two of whom agreed that "Bryan has, perhaps, undertaken a task too great for himself. He may break down physically.” Another claimed Bryan was “dangerous, because he appears to be both ignorant and sincere." 52 The questioning of Bryan’s sanity coincided conveniently with the paper's promise "to intensify its devotion to the cause of sound money.",53 What seemed insane to a New York City publisher sounded like logic to many trying to survive in agriculture during the Industrial Revolution. The transportation

\footnotetext{
${ }^{49}$ William Allen White, Autobiography (New York: Macmillan, 1946), 328.

${ }^{50}$ Ibid, 278. His later perspective reflected a more sober view of "a new figure . . . a young man ... a an intrepid advocate of a cause which he proclaimed as that of the downtrodden."

${ }^{51}$ Mark Wahlgren Summers, The Gilded Age . . ., 253.

${ }^{52}$ New York Times, September 29, 1896.

${ }^{53}$ Bruce Felknor, Political Mischief: Smear, Sabotage and Reform in U. S. Elections (New York: Praeger, 1992), 75.
} 
revolution, combined with higher tariffs, led to a situation where highly productive and hard working American farmers flooded the domestic market with more and more produce. A quarter-century agricultural depression, starting in 1873, brought farmers "from relative prosperity to perennial hard times." It did not help that corporate America expanded its wealth, prosperity, and power during much of the same period. In West Virginia and other places, credit opportunities for farmers declined while they continued to pay more than their fair share of taxes. ${ }^{54}$ Furious farmers blamed railroads for part of their plight, seeing rate discrimination as part of the problem. This rage helped to elevate E. Willis Wilson to the West Virginia governor's mansion in $1884 .^{55}$ The Populist movement emerged from a climate of fear and anger over the fate of farmers, and selected the charismatic Bryan as their deliverer. In 1896 the Democratic Party tried to tap into this mass of discontent to retain control of the presidency.

Many Democrats strategically considered that the Cleveland White House offered little alternative to the Republicans that they opposed. They also feared losing their faithful to a third party in rural areas. To maintain the cohesiveness of their party, they felt a need to turn in a radical direction (at least for that time and place). ${ }^{56}$ Cohesiveness remained an important, but nearly impossible goal in 1896 because of the Democratic absorption of the People's Party along with the nomination of that party's most visible leader. Meanwhile in West Virginia, some formed a Democratic splinter to support sound money. This went hand in hand with Henry Gassaway Davis' strong support of high tariffs. Eventually Camden and former governor A. B. Fleming joined those

\footnotetext{
${ }^{54}$ Ronald Lewis, Transforming the Appalachian Countryside (Chapel Hill: University of North Caroilina Press, 1998), 241.

${ }_{55}$ Ibid, 243.

${ }^{56}$ Eugene H. Roseboom, A History of Presidential Elections (New York: Macmillan, 1958), 308-309.
} 
rebelling against Bryan’s ideology. The “Goldbug Party” supported the Democratic State ticket and William McKinley for president. Davis eventually abandoned the gold movement and attached himself warmly to the regular Democrats. West Virginia did already have an independent Populist Party and a Farmers’ Alliance prior to 1896 which fused with the Democratic Party. Upon the Republican victory in 1896, these movements disappeared. ${ }^{57}$ All these confusing developments, combined with a divisive headline issue, helped to strengthen Republicanism in West Virginia in the buildup to the election of 1896.

Meanwhile, Republicans spoke loudly for what they called “sound money” based upon using only gold. Thomas Platt took the credit for adding the gold plank into the Republican platform that year, later calling it "my greatest triumph."58 The brief plank asserted that "The Republican Party is unreservedly for sound money. It caused the enactment of the law providing for the resumption of specie payment in 1879; since then every dollar has been good as gold."59 "Sound money” policy had domestic and foreign aspects. Inflating the currency by including silver would certainly help pare down the debts of plains farmers, but that would give them a competitive advantage over agriculture in other parts of the country. ${ }^{60}$ Bryan accused diabolical financiers of wanting to crucify mankind on a “cross of gold,” but many supported using silver if this matched policy emanating from the financial center of the world, London. Debasing American

\footnotetext{
${ }^{57}$ Ronald Lewis, Transforming the Appalachian Countryside, 245.

58 Thomas Platt, Autobiography (New York: Arno Press, 1974), 312.

${ }^{59}$ The Republican Party Platform, 1896, http://projects.vassar.edu/1896/gopplatform.html.

${ }^{60}$ Mark Wahlgren Summers, The Gilded Age, 253.
} 
currency needlessly in the face of British competition was, to gold standard supporters, a recipe for a needless obstacle in the game of international competitive commerce. ${ }^{61}$

Alongside the trumpeting of sound money for a solid economy, the Republican Party nominated William McKinley for president. McKinley moved from Ohio to the national stage in 1892 while stumping for Benjamin Harrison. His amiability in intimate surroundings with Republican officials and supporters contrasted favorably with the socially awkward president. McKinley and Hanna had to have realized that this comparison would leave a lasting impression on potential delegates in 1896. He needed to impress the rank and file party men because McKinley had no intention of currying favor with the bosses to win nomination. In the spring of 1896, McKinley’s campaign skirted the bosses and appealed to the delegates. This irritated leaders such as Elkins and also created rifts between bosses and the McKinley enthused middle men of the party.

Continual focus on economic issues bore fruit. Many voters lost confidence in the Democratic Party's ability to restore prosperity following the economic collapse of the early 1890s. A journalist of the time explained that the silver issue promised hope to those in debt because they wanted to inflate the currency. Eastern creditors naturally wanted money to retain its value. ${ }^{62}$ Across the South and the border regions, the depression hit railroads particularly hard. Except for the Louisville and Nashville, every southern rail line fell into bankruptcy. That included the Baltimore and Ohio which succumbed in $1895 .^{63}$ Coal prices by 1894 reached their lowest level in two decades. ${ }^{64}$

\footnotetext{
${ }^{61}$ Walter Russell Mead, Special Providence: American Foreign Policy and How It Changes the World (New York: Routledge, 2002), 111.

${ }^{62}$ William Allen White, Autobiography (New York: Macmillan, 1946), 275.

${ }^{63}$ John Alexander Williams, Appalachia, (Chapel Hill: University of North Carolina Press, 2002), 233.

${ }^{64}$ Ron Eller, Miners, Millhands, and Mountaineers: Industrialization of the Appalachian South, 1880-1930 (Knoxville, University of Tennessee Press, 1982), 128.
} 
The collapse of coal and railroads made debates over tariffs and the gold standard more than academic. At a time when the Democratic Party divided over economic solutions for the nation, Republicans presented a plan of action. In the months leading up to the convention, the main question was whether or not the likely nominee would stand behind it in its entirety.

Opposition and resistance from Thomas Platt and others simply made McKinley and his campaign "against the bosses" that much more popular. ${ }^{65}$ Platt later dismissed McKinley as being "not a well-balanced man of affairs. He is simply a clever gentleman, much too amiable and much too impressionable to be safely trusted with great executive office." ${ }^{\prime 66}$ What Platt really disliked was the influence of Mark Hanna’s liberal approach to industrialism and lukewarm commitment to gold. According to Platt, Hanna the politician wanted to see McKinley back away from a solid gold stance to placate southerners and westerners. ${ }^{67}$ Although McKinley did eventually back the gold plank, the ambiguity of his campaign’s stance that spring earned the bosses’ displeasure and reflected the age old political struggle between ideology and the need to meet what the people want. When McKinley finally played his card and supported gold, he worked hard not so much to meet what the voters thought they wanted, but to educate them on what he thought they needed.

McKinley's preconvention assault, especially on the border states, bore fruit in getting him the nomination. Voters in these states also followed him in the general election as well, signaling a shift towards the Republicans especially in West Virginia.

\footnotetext{
${ }^{65}$ Paul W. Glad, McKinley, Bryan, and the People (Chicago: Iva R. Dec, 1964), 102.

${ }^{66}$ Thomas Platt and Louis Lang, The Autobiography of Thomas Collier Platt (New York: B. W. Dodge and Co, 1910), 312.

${ }^{67}$ Ibid, 312, 326.
} 
This came not as a result of a sudden change of heart, or because of McKinley charisma, but from long term adjustments in the political landscape. Republican hard work and Democratic factionalism both created the 1896 GOP triumph in West Virginia and across much of the nation. More than one contemporary cited economic reasons for the McKinley sweep. Although Mark Hanna directed the most costly presidential campaign in history, it succeeded in persuading the middle class that a gold standard protected their savings. Workers believed that Bryan's agrarian policies would result in the shutdown of American industry. The "debtor states" of the South and West favored Bryan. He retained enough of a war chest to present his case, but only those that benefited from a debased currency favored it. ${ }^{68}$

Some Republicans later identified as Progressive disliked the Hanna pamphlet blitz. Theodore Roosevelt, prior to his own presidential campaigns, commented that McKinley’s manager "advertised McKinley as if he were a patent medicine.”69 Historian Bruce Felknor describes the 1896 contest as one of marketing and sees McKinley’s effort as being one of the forerunners of modern campaigns run by Eisenhower, Kennedy, and others. Felknor interprets such "appeals to democracy" with dismay. ${ }^{70}$ On the other hand, candidates that stuck to abstract principles and avoided appealing to the people in some fashion tended to lose national campaigns. The campaign approach of Hanna kept McKinley on his front porch to give speeches, but took the message of the candidate and his party to as many homes as possible. Changes wrought by the industrial revolution, such as higher rates of literacy and less expensive means of printing and distributing materials, helped Hanna mimic the success of the news media in reaching more and more

\footnotetext{
${ }^{68}$ White, Autobiography, 285.

${ }^{69}$ Felknor, Political Mischief: Smear, Sabotage, and Reform in U. S. Elections, 19.

${ }^{70}$ Ibid.
} 
homes. George W. Julian bemoaned what he saw a degeneration of American politics, comparing 1896 to the presidential election of 1852 when he alleged that "nothing is to be deplored more than the statesmanship which employs its time in finding out which way the wind blows and trimming its sails accordingly, instead of bravely appealing to fundamental principles as its never failing guide." ${ }^{71}$ The organization of the national campaign helped to boost other Republican candidates as well. It must be remembered that elections for state legislatures had national implications because of their selection of Senators. That meant that issues such as the tariff had meaning even in House of Delegates and Senatorial elections.

McKinley's preconvention campaign in West Virginia produced strains within the state party. Political organizations rarely work with precision. The people involved have their own ambitions and sense of their proper place in the grand design. Often this conflicts with the vision of the organization and its leadership. The presidential election of 1896 illustrates this point. Elkins’ stature as a first term senator was unusual. House Republican leader J. M. Cannon saw Elkins as a key part of his plan to organize enough votes to gain the speakership. ${ }^{72}$ Elkins' support in the election of 1896 was seen as significant by the major contenders, although he himself desired to see Harrison return. ${ }^{73}$ Harrison presented a safe choice in a field crowded with fellow US Senators, but he decided not to run.

Meanwhile support at the lower levels swelled in favor of William McKinley, a Union Army Major and a popular Ohio politician. McKinley held a lot of strong cards in terms of his aspiration for the presidency. He had few real enemies because of his great

\footnotetext{
${ }^{71}$ George W. Julian, “Some Ante-Bellum Politics” North American Review 163 (August 1896): 206.

${ }^{72}$ Cannon to Elkins, November 22, 1895, Elkins Papers.

${ }^{73}$ Elkins to Harrison February 3, 1896, Ibid.
} 
charm and talent for avoiding controversy or confrontation. McKinley also had an energetic organization man clearing the road for his nomination. Marcus Alonzo Hanna had taken full advantage of the opportunities presented during the industrial revolution to construct a respectable business empire around Cleveland, Ohio. Harold Ickes found him “a likeable man" and Hanna preached cooperation instead of conflict. ${ }^{74}$ Hanna was one of the first major industrialists to bargain in good faith with his workers and tried to pay his workers above the industry standards. He prided himself on having an open door policy. Hanna also worked devotedly for the younger William McKinley, making his ascension to the presidency his life's ambition.

Hanna worked doggedly to secure support. McKinley refused a potential deal brokered between Hanna on one hand and Platt and Quay on the other, replying "Mark, some things come too high. If I were to accept the nomination on those terms, the place would be worth nothing to me and less to the people.” Undeterred, Hanna helped his candidate craft a "People Against the Bosses" campaign for the nomination. ${ }^{75}$ This signified a break from the old alliance between Republican presidential candidates and urban or state bosses, forcing Elkins as a man of ambition and authority to adjust to the changing political mood. Despite the friction between the McKinley campaign and Elkins, relations warmed quickly. Mark Hanna arranged for aid to West Virginia Republicans, writing Elkins that "some of my friends in Pittsburgh have agreed to help Dayton” and "I have sent Scott a personal contribution.,76

\footnotetext{
${ }^{74}$ Francis Russell, The President Makers From Mark Hanna to Joseph P. Kennedy (Boston: Little Brown, 1976), 2.

${ }^{75}$ Ibid, 488

${ }^{76}$ Hanna to Elkins, October 21, 1898, Elkins Papers.
} 
By March of 1896 Elkins’ West Virginia allies found themselves swept up in the strong momentum towards a McKinley nomination. The candidate's campaign officials actively cultivated such close Elkins lieutenants as Mason and Hart. To the dismay of his allies, Elkins refused to join the McKinley bandwagon. Elkins explained to Mason that "McKinley is making great strides, but his nomination is not yet assured.” He wanted Mason to recruit "sensible” delegates that remained "unpledged and uninstructed.,77 Pressure continued to build among McKinley supporters and Elkins’ allies remained confused about his unwillingness to commit on the future president. Reluctance to side publicly with McKinley made Elkins appear as one of the bosses on the wrong side of history as far as this election was concerned. Likely, Elkins saw no point in alienating men such as Platt or Quay. Platt said McKinley was "not a well-balanced man of affairs" and "much too impressionable to be safely trusted with great executive office."78 Then again, McKinley had refused to cut deals with men such as Platt, so the criticism should be taken with a grain of salt. Elkins held a confidential position that he did not want West Virginia delegates instructed as to whom they ought to vote for when they attended the 1896 Republican National Convention. Only a few were privy to Elkins' wishes on this point.

The McKinley campaign successfully sowed friction in the state party. McKinley men accused Elkins of preventing West Virginia, Kentucky, and New Mexico delegates from joining the movement. ${ }^{79}$ Before the onset of primary voting, most conventions had an aura of uncertainty. Like a papal conclave, the favorite often did not get the prize.

\footnotetext{
${ }^{77}$ Elkins to Mason, March 20, 1896, Mason Papers.

${ }^{78}$ Platt, Autobiography, 312.

${ }^{79}$ Grosvenor to Mason March 31, 1896, Mason Papers. Also Grosvenor to C. B. Hart, undated, Mason Papers.
} 
McKinley wanted a convention stacked with pledged delegates and even exerted direct pressure to try and recruit them. A personal letter from the likely future president combined with constant haranguing by campaign officials often produced the desired effect. ${ }^{80}$ Mason, Hart, and White constantly badgered Elkins to change his mind on McKinley.

By April, Elkins grew frustrated. His allies concluded that Elkins refused to agree to an instructed delegation because of a continued flicker of hope that Blaine might win over the St. Louis convention. ${ }^{81}$ An increasingly annoyed Elkins granted different explanations to different allies. To White he explained that West Virginia "has not been instructed since 1880 and I think it is well to keep up our traditions. ${ }^{„ 82}$ Elkins himself received no support in earlier election cycles when he tried to get delegations instructed for Harrison while a member of his Cabinet. Why should he allow what was not permitted to him? ${ }^{83}$ Elkins later wrote that he did not oppose McKinley, but feared that his friends would raise his name against McKinley in the convention. ${ }^{84}$ As a U. S. Senator and former Secretary of War, such a nomination did not lay outside the realm of possibility, but Elkins wanted no part of the presidency despite speculation from the Washington Post. ${ }^{85}$

Mason received a more plausible explanation. Elkins, like future senators from West Virginia, saw economic value in federal investment in his state. A first term U. S. Senator must scratch and claw for appropriations. In the spring of 1896 he successfully

\footnotetext{
${ }^{80}$ McKinley to Mason April 1, 1896, Mason Papers.

${ }^{81}$ Hart to Mason April 7, 1896, Mason Papers..

${ }^{82}$ Elkins to White April 10, 1896, A. B. White Papers.

${ }^{83}$ Elkins to Mason, May 6, 1896, Elkins Papers.

${ }^{84}$ Elkins to White, April 15, 1896, A. B. White Papers.

${ }^{85}$ Washington Post , May 15, 1896.
} 
battled for a major appropriation to improve the Monongahela River between Fairmont and Morgantown. The original proposed appropriation of $\$ 20,000$ would be raised to over $\$ 1$ million if the government bought a series of privately owned dams. Eventually the money spent on the project topped $\$ 1.13$ million. Elkins explained that the Senate contained more presidential hopefuls than simply McKinley and asked, "Do you think under the circumstances it would have been wise ... to put in rousing instructions for McKinley?»86 Mason found himself in a challenging position between two political titans because the pressure filled correspondence from McKinley continued. It worked because Elkins continued to defend his position throughout April and May. During the Second District convention Mason acknowledged that Elkins did not want instructions, causing the senator to erupt in angry sarcasm. Elkins wrote, "I am sure you will agree after what I said above and what I have said and wrote to my friends, you among the number, that you had no right to [complain.]" Furthermore, he assured Mason that he was "glad to say our appropriations has passed the conference, the only fear now is that also you might tell our friends. ${ }^{87}$ He soon swallowed his rage and on May 19, Elkins told Mason that the issue now was "to get votes for McKinley. That is before us; the other is behind us. What is before us we must now attend to loyally."${ }^{88}$ Elkins used a pragmatic leadership style that focused on the big picture, but also forgave subordinates for not necessarily comprehending his strategy.

In the end the convention passed on instructions in lieu of a resolution, a compromise proposed by Elkins. ${ }^{89}$ White played a rather disingenuous role, approving of

\footnotetext{
${ }^{86}$ Elkins to Mason April 10, 1896, Mason Papers.

${ }^{87}$ Elkins to Mason May 16, 1896, Elkins Papers.

${ }^{88}$ Elkins to Mason May19, 1896, Mason Papers.

${ }^{89}$ Elkins to Mason, May 6, 1896, Mason Papers.
} 
instructions when corresponding with Mason in April, but expressing impatience to Elkins over Hart's role in pushing McKinley's agenda. ${ }^{90}$ The tensions created during the election of 1896 showed how easily outside interests could manipulate even long-time cogs in the political machine. The allure of close relations with a future president caused Mason to drive Elkins to distraction and the two never returned to their previously warm relationship. Although the McKinley campaign reassured Mason that the president would remember his friends in West Virginia, he experienced a disappointing blow when denied a lucrative patronage job in $1897 .^{91}$

Mason blundered because he failed to understand his position. McKinley knew how to boost the ego of the long-time local political operator. Personal letters and pleas, some of which implored Mason’s confidentiality, bolstered Mason’s sense of importance. McKinley trusted in the self-interest of Mason. In this manner McKinley's campaign pried him away from Elkins' influence. By 1897, McKinley had ascended to the position of a political star around which Elkins' planet would have to orbit. Elkins dutifully aligned himself. Mason forgot that he remained a satellite of Elkins in this manner of describing the political system. After demonstrating his lack of loyalty in the spring of 1896, he still expected Elkins to help him achieve his goals. From his position in Marion County he could not understand the political landscape as Elkins did. The senator had to balance his goals as political leader of West Virginia with his role as United States Senator. Elkins did not have the luxury of ignoring those considerations, and to his credit, he placed the needs of the state over the needs of his political party. He continued to turn federal dollars towards West Virginia, as in the 1898 establishment of a weather

\footnotetext{
${ }^{90}$ White to Mason, April 28, 1896, Mason Papers and also White to Elkins May 18, 1896, A. B. White Papers.

${ }^{91}$ Elkins to Mason, April 14, 1897, Mason Papers.
} 
station at Elkins. However, Elkins showed too much reliance on the idea of loyalty and obedience and expressed frustration when his chieftains followed what they perceived to be their own self-interest. Returning to the fold proved painful for Mason. McKinley's people inflated his sense of self-importance and reality set in cruelly.

Elkins treated Mason with patience and fairness despite his irritation. Instead of confronting those who disagreed with him, Elkins preferred to remain above the fray, dispatching subordinates to handle work that might cause discontent or controversy. William Mercer Owens Dawson served as one of Elkins' trusted right hand men running the Republican Executive Committee. In this post the former Preston County editor administered the party but did not lead it. He maintained an almost encyclopedic knowledge of people, places, and their proclivities, advising but never seizing real initiative. Dawson also helped to manage issues of patronage and money, at times a thankless task. Williams credits Dawson for giving the state Republicans a modern organization in 1892 for the first time. ${ }^{92}$ His reward eventually came in the form of the governor's mansion. John W. Mason, friends with Elkins even before his move to West Virginia, also worked to advance his program at least most of the time. Mason could often be more trying as a friend than others were as enemies. If the Elkins organization had a fundamental principle, it seemed to lie in keeping people as content as possible. This reflected other political authorities at the time. As Mark Wahlgren Summers explained “A smart boss couldn’t boss.” In all fields they had to give, or at least give the appearance of providing everyone an honest hearing. The multiplicity of government officials at all levels made a single leader more, not less, essential. ${ }^{93}$ A strong

\footnotetext{
${ }^{92}$ Williams, West Virginia and the Captains of Industry, 55.

${ }^{93}$ Mark Wahlgren Summers, The Gilded Age ...., 182.
} 
organization at the state level working with an increasingly assertive, well-funded, and focused national party helped the Republican Party achieve its goal of disseminating its message.

The role of these voters remains vital. People tend to determine what their interests are on an individual basis, then make political decisions based upon them. Individuals make choices based upon a variety of reasons; even those responding to social pressures have to make a choice to submit, instead of reacting against them. By the 1890s the splits in the Democratic Party, social unrest, and hard times pushed their voters towards the Republicans. The early 1890s witnessed West Virginia Republicans developing a clear message as well as a strong organization. The national clarion call lay in "sound money." In early 1896, the Wall Street Journal quoted an unnamed industrialist who clamored for such a candidate. Discounting Democratic prospects, he promised to "buy stocks freely" upon the nomination of a sound money man. The platform made no difference to him. ${ }^{94}$

In 1896, the GOP returned to the Governor's Mansion for the first time in two decades. Some of Goff's former supporters now had grown entrenched into the Elkins camp. These included the ambitious Nathan B. Scott and the popular George Wesley Atkinson. Atkinson's pure conventionality in all fields combined with his prolific writings make him an ideal case study. The local color movement of late nineteenth century American literature saw middle class writers from major cities write tales of love, conflict, and scenery in what they considered the exotic Appalachians. Travelers into the Appalachians found resorts featuring all the modern comforts plus breathtaking scenery. These combined with visions of lifestyles and poverty that they believed formed a

\footnotetext{
${ }^{94}$ Wall Street Journal, March 26, 1896.
} 
different social world than theirs (despite the fact that most of these people lived fairly close to urban poverty that they generally ignored). The apparent surrealism inspired both writers and audiences to ponder the existence and meaning of the supposed Appalachian way of living. Atkinson’s contributions included the epic poem "Maid of the Cumberland or The Sad Fate of the Moonshiner's Daughter: A Legend of the Cumberland Mountains.” Atkinson drew upon his experiences as a revenue agent to produce this work that would probably today carry the caveat "based on a true story." Local color writers generally play upon the cultural differences between "mountain people” and "outsiders.” Here Atkinson uses a typical device with a twist. These stories often portray romantic attachments between a local girl and a "civilized" outsider. In this case it is a revenue agent working undercover trying to infiltrate a moonshine ring. He courts a naïve young woman who brings him inside their circle. Once the agent obtains the secret location of the still, he leads the raid. Dramatically, Atkinson wrote "On, on they rode at rapid gait/To vindicate the laws of State.” It would not be local color if he failed to mention the scenery, "above were peaks where Nature hung/ And crags and cliffs that Pluto flung."95

Atkinson's work never had the impact of John Fox Jr. or Mary Noailles Murfree. Historians often point out the influence that Fox's writings had on early $20^{\text {th }}$ century sociologists as well as influential amateurs such as Harry Caudill, but Atkinson was both a local color writer and a state governor. He came from a party that supported industrial expansion, but also drew inspiration from the scenery of the region and his own experiences battling the illegal whiskey trade. Although a West Virginian, Atkinson held

\footnotetext{
${ }^{95}$ George Wesley Atkinson, Maid of the Cumberland or The Sad Fate of the Moonshiner's Daughter: A Legend of the Cumberland Mountains (Washington: Rufus Darby, 1891.)
} 
the kinds of middle class American values that led to the belief that "backwards peoples" could be uplifted by both the profit and missionary motives. ${ }^{96}$ Politicians waxing romantic through prose did not strike the Victorian mind as odd. Lord Beaconsfield, born Benjamin Disraeli, led the British Conservative Party, served as Prime Minister, and wrote flowery novels.

Although living on the precipice of the Progressive Era, Atkinson trusted the individual over the collective but could not always escape political contradictions. His treatises on ethics and psychology emphasized the worthiness of the disciplined individual over the degeneracy and naiveté of the masses. This conclusion taps into a tradition of political philosophy running from Aristotle through James Madison into the Second Industrial Revolution. Democracy to the ancient Greeks meant mob rule. Madison feared that an unchecked "pure democracy" was "incompatible with personal security or the rights of property."97 This conflicted with the predominant Jacksonian natural rights ethic of Atkinson's region, but not as often the middle and upper classes, many of whom gravitated towards positivism, partly through Charles Darwin's theories on evolution and their impact upon science. ${ }^{98}$ The influence of Darwin and American writers such as Edward Livingston Youmans in the decades after the Civil War formed the foundation of some theories explaining human development. Darwin stated that no difference existed in the base emotional or mental functions of humans and other mammals. Youmans built on this by asserting that the basic emotional nature of human

\footnotetext{
${ }^{96}$ Eller, Miners, Millhands, and Mountaineers, 43.

${ }^{97}$ James Madison, Federalist 10 in Alexander Hamilton, James Madison, John Jay, The Federalist Papers (New York: Mentor, 1999), 49.

${ }^{98}$ Daria Frezza, The Leader and the Crowd: Democracy in American Public Discourse. 1880-1941 (Athens: University of Georgia Press, 2007), 25.
} 
beings explained "quackeries of the platform, the bar, the state house, and the pulpit." "99 Social Darwinism meant that each individual has his destiny in his own hands and must ensure his own "survival.”

Atkinson's works combined social science with American Protestant morality based on such assertions as "God allows every human being to do as he pleases, but holds him accountable for his acts." ${ }^{\prime 100}$ For this work the future governor actively sought the advice of Alston Gordon Dayton, whom he asked to "rouse up all your old symptoms of

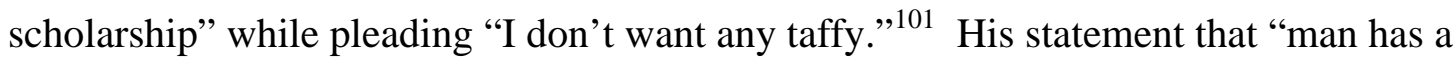
triple nature, body, soul, and spirit” places him in a similar intellectual tradition as Youmans, but he quotes 1 Thessalonians 5:23 rather than psychology pioneers as proof. ${ }^{102}$ To Atkinson, psychology exists as a way to do as Socrates preached, "know thyself." It is an "investigation for one’s self" that "develops self-control.” When an individual develops self-control, he forms good character, which Atkinson argues is essential to happiness. ${ }^{103}$

Historian Heather Cox Richardson described how similar social theories gained popularity throughout the United States at this time. Atkinson seems to be influenced by William Graham Sumner who preached lasseiz-faire for individuals, but government activism to benefit business. A popular professor of economics and sociology, Sumner argued that each man controlled his own effort and choices and deserved to reap the results of each. Social planning only ended with poor results and increasing burdens on

\footnotetext{
${ }^{99}$ Merle Curti, Human Nature in American Thought (Madison: University of Wisconsin Press, 1980), 196197.

${ }^{100}$ George Wesley Atkinson, Psychology Simplified (Charleston WV: Donnelly Publishing, 1897.)

${ }^{101}$ Atkinson to Dayton, January 21, 1898, Dayton Papers.

${ }^{102}$ Ibid., 21.

${ }^{103}$ Ibid., 39.
} 
the producers. He supported a completely lasseiz-faire system free of government interference on behalf of both individuals and also monopolistic corporations seeking public assistance to maintain themselves. ${ }^{104}$ Sumner's unnamed hero was the "Forgotten Man" whose taxes paid for the "paternal theory of government." Sumner taught that the only sound plan for Americans lay in the concept of "mind your own business.”105

Atkinson's philosophical treatise Don't: Or Negative Chips From Blocks of Living Truths, shows him at possibly his most pompous and preachy. It is a moral inquiry into the word that forms the title of the book and shows the future governor straining hard to be considered an intellectual as well as a moralist. Those who "sow sins ... reap sins." This includes people who drink alcohol and gamble. Their "harvest" includes "red eyes, red noses ... misery and woe" as well as "loss of property and reputation and good name and influence."106 The 1880s saw a splinter break off of the Republican Party when it refused to endorse prohibition. Statemaker Republican Thomas Carskadon ended his long affiliation with the Republicans over the issue. Atkinson's works show that a strong prohibitionist stream remained in the GOP despite the breakaway movement.

According to Atkinson, the happiest people live "a life of earnest toil," while those who do little find existence "enervating and exhausting."107 While most people are "honest, conscientious, and true," -Atkinson painfully confesses that "the great

\footnotetext{
${ }^{104}$ Merle Curti, Human Nature in American Thought (Madison: University of Wisconsin, 1980), 222-223.

${ }^{105}$ Heather Cox Richardson, Death of Reconstruction (Cambridge MA: Harvard University Press, 2001), 190-91.

${ }^{106}$ George Wesley Atkinson, Don't: Or Negative Chips From Blocks of Living Truths (Wheeling WV: Daily Intelligencer Press, 1887), 2, 19. The publisher may indicate that this was a tool that Atkinson may have used to increase his political reputation.

${ }^{107}$ Ibid., 31.
} 
multitude of people ... never pretend to think for themselves."108 In this work, he writes on one of his favorite themes of self-reliance, asserting that if everybody develops themselves to their own fullest potential, society as a whole benefits. "There is a vast difference between selfishness and a proper appreciation of self-interest.” Atkinson goes on to explain that the selfish "have exclusive regard for their own interests or happiness" however "if any provide not for his own and specially for those of his own house [he] is worse than an infidel.”109

The philosophy that emerges reflects the convention of the times. To some modern ears the sentiments expressed appear idealistic, yet self-serving. Idealism rarely survives the fire of real world trials and these works are no different. Atkinson's employment in 1900 of Detective Willliam Gibboney Baldwin (feared in some criminal circles as "the Terror of Bluefield") to ferret out "kickers” might strike some as more along the lines of bare knuckled politics than an idealistic tactic. ${ }^{110}$ Even some of his more jaded contemporaries in state Republican politics seemed to see "Brother Wesley" as "something of a ninny." "111 His letters at times suggest an almost hysterical emotionalism. Atkinson’s philosophy comes from an individualist tradition that emphasizes free will, but reaches toward conclusions that form the foundation of the Progressive movement. Human beings have the capacity for good or error, but often choose wrong. Atkinson embraces a very black and white viewpoint common to many at the time. For example, it is not overindulgence in alcohol or gambling that causes

\footnotetext{
108 Ibid., 51, 117.

${ }^{109}$ George Wesley Atkinson, Don't, 132.

${ }^{110}$ Quotation “Terror of Bluefield” from John A. Velke III, The True Story of the Baldwin-Felts Detective Agency, (John A. Velke III, 2004), 3. Original source, Roanoke Times, May 15, 1891. Employment of Baldwin from Governor Atkinson to W. M. O. Dawson, October 15, 1900, Elkins Papers.

${ }^{111}$ John Alexander Williams, West Virginia and the Captains of Industry, 84.
} 
problems, but engaging in these behaviors at all. In Don't, he clearly states “from every cradle to every grave, two roads lead out ... one of these roads is right, the other is wrong. One leads to success, the other ruin."112 Atkinson's works reveal an inner conflict between rugged individualism and his pious Methodism. All humans have the natural right to make choices and the responsibility to live with them, but people too often make the wrong choices. Atkinson sees the individual as responsible for imposing discipline, but a reader does not get the feeling that he trusts that faculty in every person. The doctrine of his times, however, blocks him from moving towards the Progressive ideal of mass action. Certainly history demonstrates that mass action, as Madison feared, can lead to great evil as well as good. These insights into Atkinson's personal belief system give more context to his political life.

Atkinson enjoyed popularity among the people, if not always other state level political figures. He did not fit snugly with political operator lawyers like John Mason, men of capital such as Elkins, or even the former newspaper editors in the mold of Dawson. ${ }^{113}$ Atkinson elicited expressions of flat out irritation from A. B. White. He first proclaimed that he would remain neutral in a dispute over a patronage office that White desired, but then told White that his appointment would "be a serious mistake."114 Atkinson brought a quixotic and professorial mindset into politics that irritated some and was tolerated by most. However, as governor Atkinson demonstrated political pragmatism, such as when he appointed some “Gold” Democrats into state government. ${ }^{115}$ He also fought to strengthen laws to protect game and fish. ${ }^{116}$

\footnotetext{
${ }^{112}$ George Wesley Atkinson, Don't, 2.

113 John Alexander Williams, West Virginia: A History (Morgantown: WVU Press, 2001), 119.

${ }_{114}$ Atkinson to White June 9, 1897, then June 10, 1897, White Papers.

115 Atkinson to White, April 2, 1897, White Papers.
} 
Interestingly Atkinson blasted Southern race policies, condemning one who opposed black education as a man seeking to "vent his narrowness." ${ }^{\text {117 }}$ This complex man carried the statewide banner for the Republican Party and won in 1896. He summed up nicely the sentimentality of the time, but also the contradictions. Atkinson comfortably preached lasseiz-faire government and sometimes spoke in optimistic terms about the power of the individual for good, but also strongly distrusted the masses and he felt that they needed improvement despite themselves.

The election of 1896 marked a milestone in both state and national politics. Neither George Wesley Atkinson nor William McKinley fully embraced the kind of expanded government activism that characterized state and federal executive branches forty years later, but it took its first steps on their watches. Republicans won nationally because of a program that unified the party and other voters behind popular figures and defined principles. Large numbers of people across the nation could understand the apparent value of sound money and even protectionism. The Democratic platform appealed to a large, but dwindling minority of farmers while striking many others as wrong-headed, or at worst boring and incomprehensible.

Within this apparent avalanche of triumph lay signs that boded ill for the future of both the national and the state parties. Those calling themselves, depending on the generation, Liberal Republicans, Mugwumps, or later, Progressives still felt a strong sense of unease regarding the authority of state and urban boss type figures. Richard Harding Davis referred to the McKinley inauguration as a "big family gathering." He wrote positively about the "victory of sound money and principle" but looked with

\footnotetext{
${ }^{116}$ Lewis, Transforming the Appalachian Countryside, 281.

${ }^{117}$ George Atkinson, Public Addresses of George Atkinson (Charleston: Public Printer, 1901), 317.
} 
distaste upon organizations bringing banners carrying the names of Platt and Quay which "suggested not a republic of free voters but a feudal barony with serfs and retainers."118 Theodore Roosevelt's rise started the final descent of the national Republican Party into the painful schisms of 1912. Elkins faced his own state level revolt in 1900.

West Virginia's transition from Democratic to Republican dominance reflected changes occurring throughout the region marked out by the Potomac, Ohio, and Missouri rivers. Kentucky and Maryland saw a resurgence of Republican activity that did not last while West Virginia and Missouri showed marked Republican tendencies. This border state region saw the GOP achieve its best successes with its late nineteenth century strategy of appealing to the preponderant public interest in prosperity and development. Development concerns and Democratic division defined politics in these states. Their similarities marked them as an almost separate region in American history, distinct from their Southern and Appalachian brethren.

${ }^{118}$ Scott Compton Osborn and Robert L. Phillips, Jr., Richard Harding Davis (Boston: Twayne Publishers, 1978), 45. Third quotation from authors of the book itself, not Richard Harding Davis personally. 


\section{CHAPTER EIGHT}

\section{AFTERMATH}

The bloody shirt symbolized the opening years of the Republican Party in West Virginia. Civil War memories of secession, warfare, and political reprisals shaped much of the political climate of the new state for a generation. As those memories faded, the great questions of state politics would be settled more often by the question of iron and other aspects of the Second Industrial revolution.

The 1896 election did not simply bring a Republican president to the White House and governor to Charleston. It reoriented American politics for a generation and West Virginia's even longer. The Mountain State had looked to the Democratic Party for leadership after the collapse of the West Virginia Republican movement in the early 1870s. In 1896, voters turned once again to the party that proudly claimed to have created the state. Since the state's creation, the Republican Party had changed its leadership, style, and issues. West Virginia Republicans saw party leaders come and go while increasingly promoting industrial development and protective tariffs as a solution to both business and labor woes. Stephen Elkins helped to engineer the 1896 shift, but his work came after years of patient effort by Nathan Goff. For Elkins and his party, triumph in 1896 brought challenges, but also saw the state emerge as an important force in the national political conversation. Victory and dominance encouraged some of those who chafed under the leadership of Elkins as the Republican Party itself braced for the coming of the new century. 
The culture itself changed as well. America's Second Industrial Revolution produced a much wider variety of diversions towards the end of the 1800s. People who were entertained by political speeches or who followed political melodrama in the newspapers could now go to baseball games or seek other diversions. Given the presence of disposable income, one could gain a sense of belonging by pulling for the Cincinnati Red Stockings or the West Virginia University Mountaineers almost as much as by involving oneself in a political party. Political parties adjusted to the reality that they had to compete for the attention of voters with non-political distractions. ${ }^{1}$

The Republican Party did seize victory and dominance in voter loyalty by the mid-1890s, but they failed to corral all of the factionalism. Given the nature of American politics and the parties that operate within the political system, cohesion was very likely impossible. Elkins tried to assert authority in patronage and in the backing of candidates, but still faced challenges, both large and small, to his managerial style. For instance, Elkins faced one seemingly minor challenge came from a dispute over the location of a post office while he confronted a full blown rebellion against his favored nominee for governor. This caused tremendous strain on the party itself as well as the eventual nominee and victor, A. B. White. ${ }^{2}$ Clearly a change of leadership and overwhelming success did not end the restiveness and divisiveness that had often plagued the party.

Between 1872 and 1896, the GOP struggled throughout the country to define and establish its identity. The United States was one of the few democracies to see its political parties not only survive the Industrial Revolution intact, but also thrive. One must admire the staying power of the party of Jefferson which survived the usually

\footnotetext{
${ }^{1}$ Mark Wahlgren Summers, The Gilded Age or the Hazard of New Functions, (Upper Saddle River, NJ: Prentice Hall, 1997), 261.

${ }^{2}$ White to Elkins, March 4, 1900, Elkins Papers.
} 
damning tarnish of treason, although it took years to regain the trust of voters in certain key parts of the country. From the beginning, Republicans in most of the country tried to mix financial and progressive impulses, struggling to find the right balance between the two. An uneasy dynamic developed within the party between the victory minded bosses, the idealists, and the party's voters. Oftentimes one must lump the grassroots and midlevel party officials with the voters because they sometimes jumped on the bandwagon of charismatic candidates themselves. Moneymen and bossism in the party alienated intellectuals and idealistic journalists, but not enough to cause a permanent break in the 1800s.

The party also tried to navigate through a period in which the parties increasingly tried to break down their divisive characteristics, especially localized power structures and build a more effective national organization. In most instances, the man liked best by the people could overcome opposition by the intellectuals or the bosses. The voters and bosses wanted Grant in 1872 while the Liberal Republicans hankered after the odd choice of Horace Greeley. Some in the middle, a prime example being the Wheeling Intelligencer, abandoned Greeley when he moved too far away from his Republican roots. McKinley and Hanna gained control of the process in 1896 by making bossism itself an issue and appealing directly to the people, making a public virtue out of their “disobedience.”

As much as the turn of the century looked like a new beginning for the West Virginia Republican Party, it relied upon foundations and structures put in place during the previous three decades. Elkins' successes in the 1890s could not have happened, regardless of the economic climate, without the diligent work of those who toiled before 
he arrived in the state. Nathan Goff shoved aside the statemaker generation, in part because their reliance on prohibitions against former Confederates had lost public support. They could not adapt their vision of West Virginia to compete with the Democrats in the early 1870s, many of whom backed the expansion of West Virginia mining and industry. Initially, Goff built a party based upon personal appeal and his ability to deliver federal jobs during Republican administrations. West Virginia Republicans also relied on loyal press outlets to keep the voters and activists mobilized and interested. This mimicked other state boss efforts in the 1870s, especially during the Grant presidency. Principle often played a subservient role to politics nationally. Goff did build a solid opposition party in this fashion. He used patronage to recreate the structure of the organization. Goff's abilities and influence gained him national recognition through his brief appointment to the cabinet. He also helped to lead the battle for the protective tariff once elected to Congress. West Virginia Republicans led by Goff could not convince state voters to restore their party to power. The Republican Party in West Virginia and across the nation eventually had to change its focus, increasingly emphasizing economic issues. Economic development had been part of the message before, but was sometimes overshadowed by Civil War rhetoric on both sides. Also the Democratic Party in the 1870s championed industrialism in a stronger fashion than their divided version in the mid to late 1880s. The 1880s in both the state and the nation were characterized by political deadlock between the Republicans and Democrats as election returns became increasingly close in many areas. West Virginia's gubernatorial race in 1888 reflected the almost equal appeal of the two parties within the state. Republicans had already started to emphasize protective tariffs as the answer to 
build American industry and protect its workers simultaneously and Goff emerged as one of the issue's most passionate advocates.

Goff led the West Virginia Republicans for a generation, but could not fend off the stronger appeal of Stephen Elkins when the latter decided to enter state politics. Elkins brought national connections and organizational experience to West Virginia that attracted many state party leaders. He also enjoyed the advantages that come from his enterprises spread across the nation and strong ties to West Virginia's industrialists. Elkins used a leadership style that minimized confrontation and encouraged cooperation while still leaving no doubt about who was in charge. The party enjoyed some success in his first few years of leadership. That being said, the economic crisis that struck the nation in 1893 pushed voters into paying more attention to the Republican economic vision. Did West Virginia’s eventual return to Republican dominance have more to do with Elkins or the economic problems sweeping the nation? Republicans had gained ground for several years in the late 1880s and early 1890s, but the breaking of political deadlock around the nation likely helped to push the Mountain State over the top.

West Virginia’s exodus from the ranks of Democratic states came at the same time as other border states. Maryland, Kentucky, and Missouri also saw their Republican parties gain more influence and win elections. This helped to push the Republican Party into power for a generation across the country. Within West Virginia, Elkins consolidated his authority but still faced challenges to his position and party unity until his death. Most significant to the Republican triumph was the message. Contrary to some popular beliefs, voters do not follow the candidate spending the most money and they do not simply vote as they are told. Voters by and large vote based upon their self- 
interest, which is not always monetary. They might vote for candidates that promise to create better opportunities. Voters might also find satisfaction by supporting a party that actively works to advance racial justice. These issues can be defined as self-interest as well.

Republicans triumphed in West Virginia and elsewhere because their message coincided with the voters' interest in 1894 and 1896. The Democratic Party offered their take on free trade and little else while the GOP advanced a program that promised to benefit workers and business alike. Economic disaster amplified the need for some kind of vision and the development of more sophisticated party structures helped to get the message to more voters than ever. As for the message itself, protection made logical sense, and happened to coincide with the return of prosperity. The GOP's success in reversing the poor economic trends cemented their constituency for a generation. Generally speaking, from 1896 until today the United States has witnessed its most dramatic electoral shifts during times of strong economic dislocation.

But the message did not end with economics. Within West Virginia, Republicans broke with many of the southern state parties by working to ensure black access to the vote. They also expanded commitments to infrastructure and education. Governor Atkinson in particular supported women's suffrage. Often, the men Elkins backed for governor agreed. Elkins himself put his name on an act that ended corrupt manipulation of rail rates to promote monopolies.

Organization, money, and leadership therefore only answer part of the question of why people voted to return the state to the Republican column. This research and study into this tumultuous period of the West Virginia Republican Party’s development 
demonstrates that the message must resonate with the people, addressing the issues that most concern them. West Virginia’s Republicans built an organization, adapted the national message, and presented it effectively and at the right time despite a potentially disruptive change in leadership. With its success, West Virginia took part in a major electoral shift that broke a partisan deadlock and shaped the national debate on economics and social issues for years to come. 


\title{
Bibliography
}

\author{
Primary Sources
}

Archival:

Bennett Papers, West Virginia and Regional History Collection, West Virginia University, Morgantown West Virginia.

Camden Papers, West Virginia and Regional History Collection, West Virginia University, Morgantown, WV

Archibald Campbell Papers, West Virginia and Regional History Collection, West Virginia University, Morgantown, WV.

J. M. Campbell Papers, Library of Virginia, Richmond VA.

Dayton Papers, West Virginia and Regional History Collection, West Virginia University, Morgantown, WV

Dawson Papers, West Virginia and Regional History Collection, West Virginia University, Morgantown, WV

Department of Justice Records, Record Group 60, Archives II, National Archives, College Park, MD.

Department of the Treasury Records, Record Group 56, National Archives, Archives II, College Park, MD.

Elkins Papers, West Virginia and Regional History Collection, West Virginia University, Morgantown West Virginia.

Gibbens Papers, West Virginia and Regional History Collection, West Virginia University, Morgantown, WV.

Goff Papers, West Virginia and Regional History Collection, West Virginia University, Morgantown, West Virginia.

Hall Papers, West Virginia and Regional History Collection, West Virginia University, Morgantown, West Virginia.

Lincoln Papers, Library of Congress, Washington D.C. http://memory.loc.gov/ammem/alhtml/malhome.html.

Mason Papers, West Virginia and Regional History Center, West Virginia University, Morgantown West Virginia. 
Pittinger Family Letters, West Virginia and Regional History Collection, West Virginia University, Morgantown WV.

White Papers, West Virginia and Regional History Collection, West Virginia University, Morgantown, WV.

Willey Papers, West Virginia and Regional History Collection, West Virginia University, Morgantown WV.

Newspapers and other periodicals:

Barbour Jeffersonian

Charleston Daily Gazette

Charleston Daily Mail

Horton Courier

New Era (Kingwood)

New York Daily Times/ New York Times.

New York Tribune

North American Review

Parkersburg State Journal

Parkersburg Weekly Sentinel

Phillippi Republican

Preston County Journal

Wall Street Journal

Washington Post

West Virginia Argus

West Virginia Democrat

West Virginia Hillbilly

Wheeling Intelligencer

Wheeling Daily Register

Memoirs:

MacCorkle, William, Recollections of Fifty Years, New York: G. P. Putnam, 1928.

O’ Neil, Thomas P. “Tip.” Man of the House. New York: Random House, 1987.

Platt, Thomas. Autobiography of Thomas Collier Platt. New York: B. W. Dodge and Co, 1910.

White, William Allen, Autobiography of William Allen White, New York: Macmillan, 1946. 
Other:

Adams, John Quincy. Inaugural Address. http://www.bartleby.com/124/pres22.html.

Ambler, Charles ed. Debates and Proceedings of the First Constitutional Convention of West Virginia, 1861-1863 Volume I-IV. Huntington, WV: Gentry Brothers, 1939.

Atkinson, George. Public Addresses of George Atkinson. Charleston: Public Printer, 1901.

Albert Beckley Diary, Library of Virginia, Richmond VA

Boreman, Arthur I. “Inaugural Address of Arthur I. Boreman.” West Virginia Division of Culture and History, http://www.wvculture.org/history/boremania.html.

Bryan, William Jennings. “Cross of Gold”. Democratic National Convention, 1896. http://historymatters.gmu.edu/d/5354/

Goff, Nathan. “American Markets for American Labor, April 27, 1888.” Washington: House of Representatives, 1888.

Goff v. Wilson, Supreme Court of Appeals of West Virginia, Charleston, 32 W.Va. 93; 9 S.E. 26; 1889 W.Va. Lexis 87.

Hamilton, Alexander, James Madison, John Jay. The Federalist Papers. New York: Mentor, 1999.

The Republican Party Platform, 1896, http://projects.vassar.edu/1896/gopplatform.html. Sumner, Charles. Charles Sumner: His Complete Works Volume IX. Boston: Lee and Shepherd, 1900.

United States Constitution. Article IV Section 4.

West Virginia Constitution of 1863, West Virginia Division of Culture and History, Charleston, West Virginia, http://www.wvculture.org/history/statehood/constitution.html. 


\section{Secondary Sources}

Books:

Ambler, Charles. Waitman T. Willey. Huntington WV: Standard Printing, 1954.

Ambler, Charles. West Virginia: The Mountain State. New York: Prentice Hall, 1940.

Atkinson, George Wesley. Don't: Or Negative Chips From Blocks of Living Truths. Wheeling WV: Daily Intelligencer Press, 1887.

Atkinson, George Wesley. Maid of the Cumberland or The Sad Fate of the Moonshiner's Daughter: A Legend of the Cumberland Mountains. Washington: Rufus Darby, 1891.

Atkinson, George W. Prominent Men of West Virginia. Wheeling: W.C.Callen, 1890.

Atkinson, George Wesley. Psychology Simplified. Charleston WV: Donnelly Publishing, 1897.

Baker, Jean H. The Politics of Continuity: Maryland Political Parties From 1858-1870. Baltimore: Johns Hopkins University Press, 1973.

Bensel, Richard. The Political Economy of American Industrialization: 1877-1900. Cambridge University Press, Cambridge, 2000.

Billings, Dwight et al., ed., Backtalk From Appalachia. Lexington: University Press of Kentucky, 1999.

Bluntschli, J. K. The Theory of the State. Oxford: The Clarendon Press, 1892.

Brisbin, Richard et al. West Virginia Politics and Government. Lincoln NE: University of Nebraska, 1996.

Calhoun, Charles W. Conceiving a New Republic: The Republican Party and the Southern Question 1869-1900. Lawrence: University Press of Kansas, 2006.

Cherny, Robert W. American Politics in the Gilded Age: 1868-1900. Wheeling, IL: Harlan Davidson, 1997.

Curti, Merle Human Nature in American Thought. Madison: University of Wisconsin Press, 1980.

Davis, Jefferson. The Rise and Fall of the Confederate Government Volume II. New York: D. Appleton, 1881.

Doherty, William Thomas. Berkeley County USA. Parsons: McLean, 1972. 
Donald, David. The Politics of Reconstruction, 1863-1867. Baton Rouge: Louisiana State University Press, 1965.

Eller, Ron, Miners, Millhands, and Mountaineers: Industrialization of the Appalachian South 1880-1930, Knoxville: University of Tennessee, 1982.

Felknor, Bruce, Political Mischief: Smear, Sabotage, and Reform in U. S. Elections, New York: Praeger, 1992.

Emerson, Ralph Waldo. Essays. New York: Book League of America, 1941.

Fischer, David Hackett. Albion's Seed: Four British Folkways in America. New York: Oxford University Press, 1989.

Fones-Wolf, Kenneth and Ronald Lewis. Transnational West Virginia: Ethnic Communities and Economic Change, 1840-1940. Morgantown: West Virginia University Press, 2002.

Frezza, Daria. The Leader and the Crowd: Democracy in American Public Discourse. 1880-1941. Athens: University of Georgia Press, 2007.

Glad, Paul W. McKinley, Bryan, and the People. Chicago: Iva R. Dec, 1964.

Goodman, William, The Two Party System in the United States, Princeton: D. Van Nostread Co, 1964.

Hall, Granville Davisson. The Rending of Virginia: A History. Chicago: Mayer and Miller, 1902.

Haworth, Paul Leland. The Hayes-Tilden Disputed Election of 1876. New York: Russell and Russell, 1966.

Holt, Thomas. Black Over White: Negro Political Leadership in South Carolina During Reconstruction. Bloomington: University of Illinois Press, 1979.

Hoogenboom, Ari. Rutherford B. Hayes: Warrior and President. Lawrence: University Press of Kansas, 1995.

Jordan, David. Roscoe Conkling: Voice In the Senate. Ithaca NY: Cornell University Press, 1971.

Judah, Charles and George Winston Smith. The Unchosen. New York: Coward-McCann, 1962. 
Kennedy, Paul. The Rise and Fall of the Great Powers: Economic Change and Military Conflict From 1500 to 2000. New York: Vintage Books, 1987.

Laidley, W.S. History of Charleston and Kanawha County and Representative Citizens. Chicago: Richmond Arnold, 1993.

Lambert, Oscar Doane. West Virginia and its Government. Boston: D. C. Heath, 1951.

Lewis, Ronald. Transforming the Appalachian Countryside: Railroads, Deforestation and Social Change in West Virginia, 1880-1920. Chapel Hill: University of North Carolina Press, 1998.

Loughry III, Allen. Don't Buy Another Vote, I Won't Pay For a Landslide: The Sordid and Continuing History of Political Corruption in West Virginia. Parsons: McClain, 2006.

McCullough, David. John Adams. New York: Simon and Schuster, 2001.

McGerr, Michael, The Decline of Popular Politics: The American North 1865-1928, New York: Oxford, 1986.

McKinney, Gordon. Southern Mountain Republicans, 1865-1900: Politics and the Appalachian Community. Chapel Hill: University of North Carolina Press, 1978.

McKinney, Gordon. Zebulon Vance: North Carolina's Civil War Governor and Gilded Age Political Leader. Chapel Hill: University of North Carolina Press, 2004.

McPherson, James. The Battle Cry of Freedom. New York: Oxford University Press, 2003.

Mead, Walter Russell. Special Providence: American Foreign Policy and How It Changes the World. New York: Routledge, 2002.

Morgan, H. Wayne. Hayes to McKinley. Syracuse: Syracuse University Press, 1969.

Myers, William Starr. The Republican Party: A History. New York: The Century Company, 1928.

Oates, Stephen. With Malice Towards None: A Life of Abraham Lincoln. New York: Harper Perennial, 1994.

Osborn, Scott and Robert L. Phillips. Richard Harding Davis. Boston: Twayne Publishing, 1978.

Pepper, Charles M. The Life and Times of Henry Gassaway Davis. New York: Century, 1920. 
Pulley, Raymond H. Old Virginia Restored: An Interpretation of the Progressive Impulse 1870-1930. Charlottesville: University of Virginia Press, 1968.

Rehnquist, Chief Justice William. All the Laws But One: Civil Liberties in Wartime. New York: Vintage Books, 1998.

Rehnquist, Chief Justice William. The Supreme Court. New York: Alfred Knopf, 2004. A Reminiscent History of Northern West Virginia. Chicago: Godspeed, 1895.

Rice, Otis. A History of Greenbrier County. Lewisburg: Greenbrier Historical Society, 1986.

Rice, Otis and Stephen Brown. West Virginia: A History. Lexington: University of Kentucky Press, 1993.

Richardson, Heather Cox. Death of Reconstruction. Cambridge MA: Harvard University Press, 2001.

Richardson, Heather Cox. West From Appomattox: Reconstruction of America After the Civil War. New Haven: Yale University Press, 2007.

Ross, Thomas Richard. Henry Gassaway Davis: An Old Fashioned Biography. Parsons: McClain, 1994.

Roseboom, Eugene H. A History of Presidential Elections. New York: Macmillan, 1958.

Russell, Francis. The President Makers From Mark Hanna to Joseph P. Kennedy. Boston: Little Brown, 1976.

Salstrom, Paul. Appalachia's Path to Dependency. Lexington: University of Kentucky Press, 1994.

Schlesinger, Arthur. The Age of Jackson. Boston: Little Brown, 1953.

Smith, Adam. Wealth of Nations. New York: Bantam Classic, 2003.

Smith, Gerald Wayne. Nathan Goff: A Biography With Some Account of Guy Despard Goff and Brazilla Carroll Reece. Charleston: Educational Foundation, 1959.

Smith, Jean Edward. Grant. New York: Simon and Schuster, 2001.

Smith, Jean Edward. John Marshall: Definer of a Nation. New York: Henry Holt, 1996.

Summers, Festus. Johnson Newlon Camden: A Study in Individualism. New York: G.P. Putnam's Sons, 1937. 
Summers, Mark Wahlgren. The Era of Good Stealings, New York: Oxford, 1993.

Summers, Mark Wahlgren. The Gilded Age: or The Hazard of New Functions. Upper Saddle River NJ: Prentice Hall 1997.

Summers, Mark Wahlgren. Rum, Romanism, and Rebellion: The Making of the President 1884. Chapel Hill: University of North Carolina Press, 2000.

Taylor, A. J. P. The Struggle For Mastery In Europe, 1848-1918. Oxford: Oxford University Press, 1954.

Tripp, Steven Elliot. Yankee Town-Southern City: Race and Class Politics in Civil War Lynchburg. New York: New York University Press, 1997.

Trotter, Joe William. Coal, Class, and Color: Blacks in Southern West Virginia 1915-32. Chicago: University of Illinois Press, 1990.

Velke III, John A. The True Story of the Baldwin-Felts Detective Agency. John A. Velke III, 2004.

Weber, Ralph E. ed. As Others See Us: American History in the Foreign Press. New York: Holt Rinehart, 1972.

Wiley, S. T., History of Preston County. Kingwood: Journal Printing House, 1892.

Williams, John Alexander. Appalachia. Chapel Hill: University of North Carolina Press, 2002.

Williams, John Alexander. "Davis and Elkins of West Virginia; Businessmen in Politics.” Ph.D. diss., Yale University, 1969.

Williams, John Alexander. “ New York’s First Senator From West Virginia: How Stephen B. Elkins Found a New Political Home.” West Virginia History 21 (January 1870): 73-87.

Williams, John Alexander. West Virginia: A History. Morgantown: West Virginia University Press, 2001.

Williams, John Alexander. West Virginia and the Captains of Industry. Morgantown: West Virginia University Libraries, 1976.

Zinn, Patricia Ann. "History of the Preston County Journal.” West Virginia History 32 (July 1971): 245-266. 
Articles:

Abbott, Richard, “The Republican Party Press in Reconstruction Georgia, 1867-1874.” Journal of Southern History 61 (November 1995): 725-760.

Argersinger, Peter "New Perspectives on Election Fraud in the Gilded Age.” Political Science Quarterly 100 (Winter 1985): 669-687.

Bailey, Kenneth. “A Judicious Mixture: Negroes and Immigrants in the West Virginia Mines 1880-1917.” West Virginia History 34 (January 1973): 141-161.

Bond, Donovan "How the Wheeling Intelligencer Became a Republican Organ." West Virginia History 11 (April 1950): 160-184.

Fones-Wolf, Kenneth. “A House Re-Divided: From Sectionalism to Political Economy in Post-Emancipation West Virginia” in Reconstructing Appalachia: The Civil War's Aftermath, ed. Andrew L. Slap. Lexington: University Press of Kentucky, 2010.

Harlan, Louis ”Booker T. Washington’s West Virginia Boyhood.” West Virginia History 32 (January 1971): 63-85.

Jacobs, James Henry. “The West Virginia Gubernatorial Contest: 1888-1890.” West Virginia History 7 (April, 1946): 1-43.

Julian, George W. “The Death-Struggle of the Republican Party.” North American Review. (March 1878).

Julian, George W. “Some Ante-Bellum Politics.” North American Review 163 (August 1896).

“The Political Campaign of 1872.” North American Review. (October 1872).

Shaffer, Dallas. “Lincoln and the ‘Vast Question’ of West Virginia,” 32 West Virginia History (January 1971): 86-100.

Smith, G. Wayne. “Nathan Goff Jr., In the Civil War.” West Virginia History 14 (January 1953): 108-135.

Stealey III, John Edmund. “The Freedman’s Bureau in West Virginia”. 39 West Virginia History (January-April 1978): 104.

Theses and Dissertations:

Davis, Leonard McCutcheon. “The Speeches of Nathan Goff Jr.” Ph.D. diss., Northwestern University, 1958. 
Gooden, Randall Scott. "The Completion of a Revolution: West Virginia From Statehood Through Reconstruction.” Ph.D. diss., West Virginia University, 1995.

Ray, Amanda, The Impact of Statehood and Republican Politics on Women's Legal Rightsin West Virginia, 1863-1872, Morgantown: Masters Thesis, West Virginia University, 2001.

Smith, Gerald Wayne. “Nathan Goff Jr: A Biography.” PhD Dissertation, West Virginia University, Morgantown WV. 